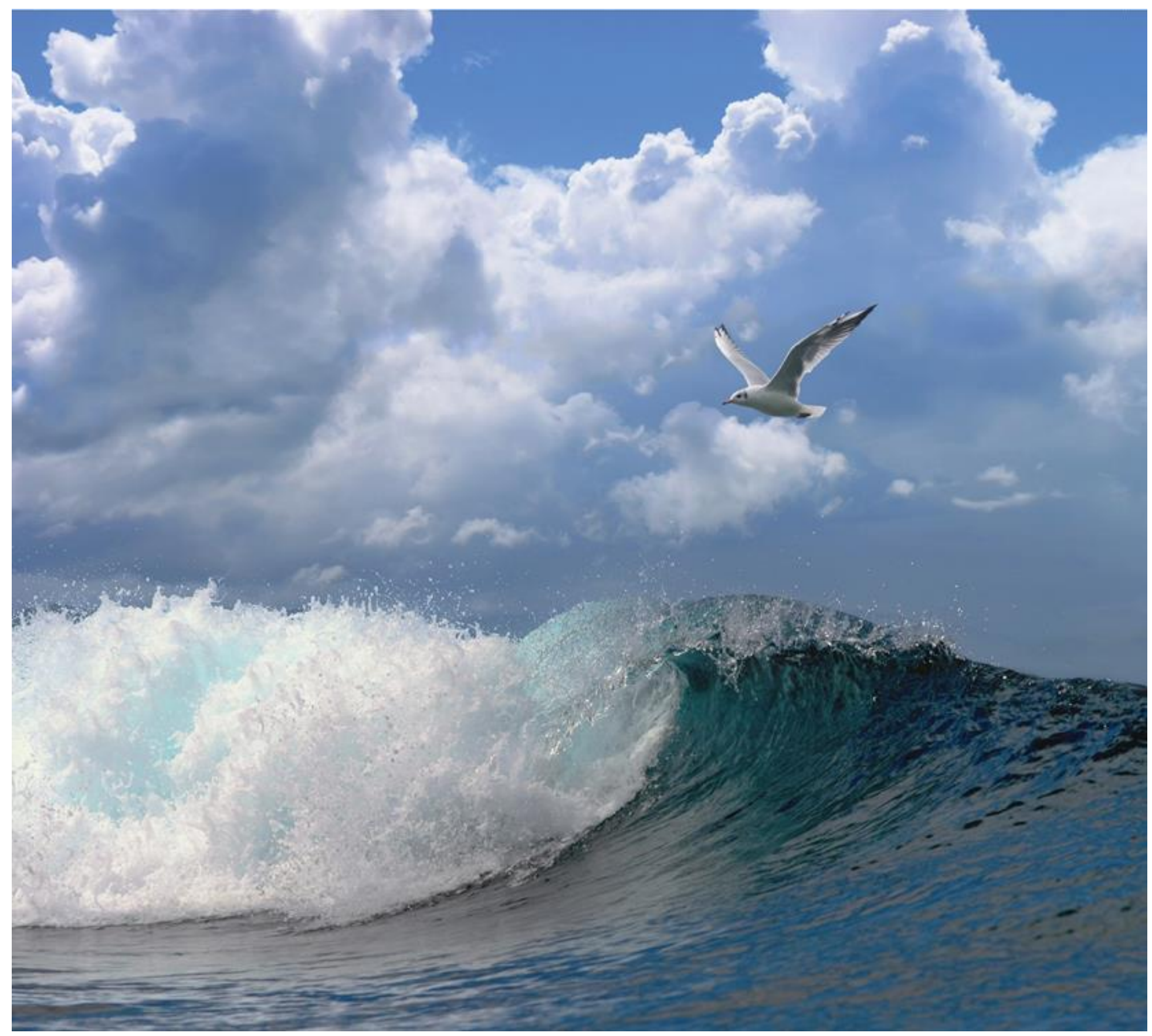

\title{
Report on the eel stock and fishery in the Netherlands 2015/2016
}




\section{Report on the eel stock and fishery in the Netherlands 2015/2016}

Author(s): $\quad$ Martin de Graaf and Oscar G. Bos

Publication date: 18 January 2017

This research project was carried out by Wageningen Marine Research at the request of and with funding from the Ministry of Economic Affairs for the purposes of Policy Support Research Theme 'WOT-05 Fisheries ' (project no. WOT-05-001-017).

Wageningen Marine Research

IJ muiden, January 2017

Wageningen Marine Research report C003/17 
De Graaf, M., Bos O.G. (2016) Report on the eel stock and fishery in the Netherlands 2015/2016. Wageningen Marine Research report C003/17.

Keywords: eel, paling, aal, Anguilla anguilla

Client: $\quad$ Ministry of Economic Affairs

Attn.: Mirjam Snijdelaar

PO Box 20401

2500 EK, Den Haag

The Netherlands

BAS code WOT-05-001-017

Wageningen Marine Research is ISO 9001:2008 certified.

Dit rapport is gratis te downloaden van https://doi.org/10.18174/404185.

Wageningen Marine Research verstrekt geen gedrukte exemplaren van rapporten.

(C) 2016 Wageningen Marine Research Wageningen UR

Wageningen Marine Research The Management of Wageningen Marine Research is not responsible for resulting institute of Stichting Wageningen damage, as well as for damage resulting from the application of results or Research is registered in the Dutch research obtained by Wageningen Marine Research, its clients or any claims traderecord nr. 09098104, BTW nr. NL 806511618 related to the application of information found within its research. This report has been made on the request of the client and is wholly the client's property. This report may not be reproduced and/or published partially or in its entirety without the express written consent of the client. 


\section{Contents}

$1 \quad$ Nederlandse samenvatting $\quad 5$

1.1 Trend glasaal $\quad 5$

$\begin{array}{lll}1.2 & \text { Trend (rode) aal Waddenzee } & 6\end{array}$

$\begin{array}{lll}1.3 & \text { Trend (rode) aal IJ sselmeer/Markermeer } & 7\end{array}$

$\begin{array}{lll}1.4 & \text { Trend schieraal } & 8\end{array}$

1.5 Trend aalvangsten beroepsvisserij $\quad 8$

$\begin{array}{lll}1.6 & \text { Trend aalvangsten recreatieve visserij } & 11\end{array}$

$\begin{array}{lll}1.7 & \text { Trend aquacultuur } & 12\end{array}$

1.8 Trend uitzet glasaal en pootaal 13

1.9 Trend vervuiling 16

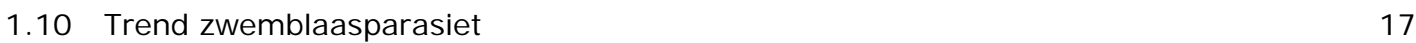

2 Overview of the stock and its management $\quad 21$

2.1 The eel stock and its management $\quad 21$

2.1.1 Eel Management Units and Eel Management Plans $\quad 21$

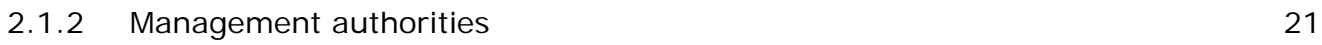

$\begin{array}{lll}2.1 .3 & \text { Regulations } & 21\end{array}$

2.1.4 Management actions $\quad 22$

2.2 Stock status $\quad 24$

2.2.1 EMP Progress Report summary table $\quad 24$

$\begin{array}{lll}2.3 & \text { Precautionary diagram } & 24\end{array}$

$\begin{array}{lll}2.4 & \text { Significant changes since last report } & 25\end{array}$

$\begin{array}{llr}3 & \text { I mpacts on the stock } & 26\end{array}$

3.1 Fisheries 26

3.1.1 General information $\quad 26$

3.1.2 Spatial subdivision of the territory 30

3.1.3 Fishing capacity 31

$\begin{array}{lll}3.1 .4 & \text { Fishing effort } & 32\end{array}$

3.1.5 Catches and landings $\quad 34$

$\begin{array}{lll}3.1 .6 & \text { CPUE } & 38\end{array}$

3.1.7 Illegal, unreported and unregulated (IUU) fishing 38

3.2 Restocking \& Aquaculture

Fout! Bladwijzer niet gedefinieerd.

$\begin{array}{lll}3.3 & \text { Aquaculture production } & 38\end{array}$

3.3.1 Seed supply $\quad 38$

3.3.2 Reconstructed Time Series on Stocking 40

$\begin{array}{lll}3.4 & \text { Entrainment } & 41\end{array}$

$\begin{array}{lll}3.5 & \text { Habitat Quantity and Quality } & 41\end{array}$

$\begin{array}{lll}3.6 & \text { Others } & 42\end{array}$

3.6.1 Assisted migration of silver eel $\quad 42$

$4 \quad$ National stock assessment $\quad 43$

$\begin{array}{lll}4.1 & \text { Description of Method } & 43\end{array}$

4.1.1 Data collection $\quad 43$

$\begin{array}{lll}4.1 .2 & \text { Analysis } & 44\end{array}$

4.1.3 Reporting $\quad 44$

4.1.4 Data quality issues and how they are being addressed $\quad 44$

$\begin{array}{lll}4.2 & \text { Assessment results } & 45\end{array}$

$\begin{array}{lll}\text { 4.2.1 Habitat quantities } & 45\end{array}$ 
5.1 International recruitment time series 46

$\begin{array}{lll}5.2 & \text { Other recruitment time series } & 46\end{array}$

$\begin{array}{lll}5.2 .1 & \text { Glass eel recruitment } & 46\end{array}$

5.2.2 Yellow eel recruitment $\quad 49$

5.3 National programme for EU Data Collection Framework or other 49

$\begin{array}{lll}5.4 & \text { Stock surveys, yellow eel } & 50\end{array}$

5.4.1 Lake IJsselmeer/Markermeer (active gear) 50

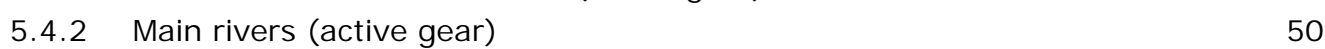

$\begin{array}{ll}\text { 5.4.3 Main rivers (passive gear) } & 50\end{array}$

$\begin{array}{lll}5.4 .4 & \text { Coastal waters (active gear) } & 50\end{array}$

$\begin{array}{lll}5.5 & \text { Silver eel escapement surveys } & 51\end{array}$

$\begin{array}{lll}5.6 & \text { Biological parameters } & 52\end{array}$

5.7 Growth, silvering and mortality $\quad 52$

5.8 Parasites \& Pathogens $\quad 52$

5.9 Contaminants $\quad 53$

$\begin{array}{lll}5.10 & \text { Predators } & 54\end{array}$

$6 \quad$ New and emerging threats and opportunities

$7 \quad$ Quality Assurance

Fout! Bladwijzer niet gedefinieerd. 


\section{$1 \quad$ Nederlandse samenvatting}

In de Nederlands samenvatting wordt een overzicht gepresenteerd van de belangrijkste trends in aal en de aalvisserij in 2015/2016 zoals deze zijn gerapporteerd in het Country Report aan de International Council of Exploration of the Sea Working Group on Eel (EIFAAC/GFCM/ICES WGEEL) in september 2016. Er is in 2016 geen verandering in de perceptie van de status van het bestand van de Europese aal. In deze Nederlandse samenvatting wordt een verkorte presentatie van de inhoud gegeven, met de nadruk op de meest recente gegevens.

\subsection{Trend glasaal}

De intrek van jonge aal (glasaal) uit zee naar onze binnenwateren wordt - in principe - bemonsterd op 12 plaatsen langs de kust (Figuur 1). Niet alle locaties worden elk jaar bemonsterd. Bij Den Oever wordt sinds 1938 een intensieve bemonstering uitgevoerd.

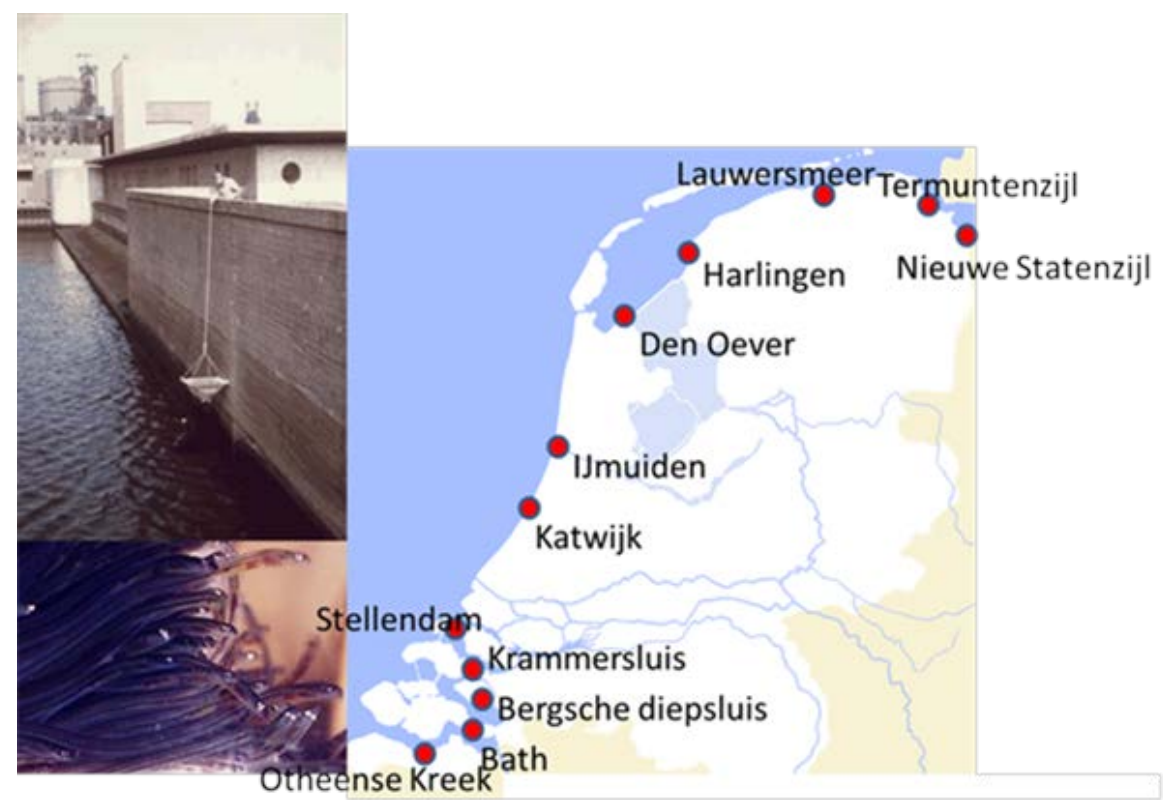

Figuur 1. Locaties van de glasaalmonitoring in Nederland.

Er wordt al enkele jaren niet meer gemonitord op de locaties 'Otheense Kreek' en 'Scheepssluis Den Oever'. Op de locaties Lauwersmeer zijn in 2015 geen metingen verricht. Voor deze locaties worden voor 2017 nieuwe vrijwilligers gezocht.

Het niveau van de intrek bij Den Oever dit voorjaar (2016: gemiddeld 0.96 glasalen per kruisnet-trek) was laag in vergelijking met het vroegere niveau en is vergelijkbaar met het niveau van de intrek in de jaren 2002, 2011 en 2012. In vergelijking met 2015 is in 2016 bij zes van de acht locaties de intrek toegenomen (zie Engelse deel, paragraaf 5.2.1). De resultaten van de langjarige intrekbemonstering bij Den Oever (locatie 'Spuisluis') tonen een sterk verlaagde intrek na 1985 (Figuur 2). Het gemiddelde niveau van de glasaalintrek in de laatste 15 jaar (2002-2016: gemiddeld 1.6 glasalen per kruisnet-trek, zie inzet in Figuur 2) is minder dan 5\% van het vroegere niveau (19601979: gemiddeld 64 per kruisnet-trek). Internationaal is de glasaalintrek in 2016 ongeveer gelijk als in 2015. De internationale glasaal index blijft in 2016 zeer laag met 2.7\% t.o.v. het gemiddelde van 1960-1979 (vroegere niveau) (ICES 2016). 


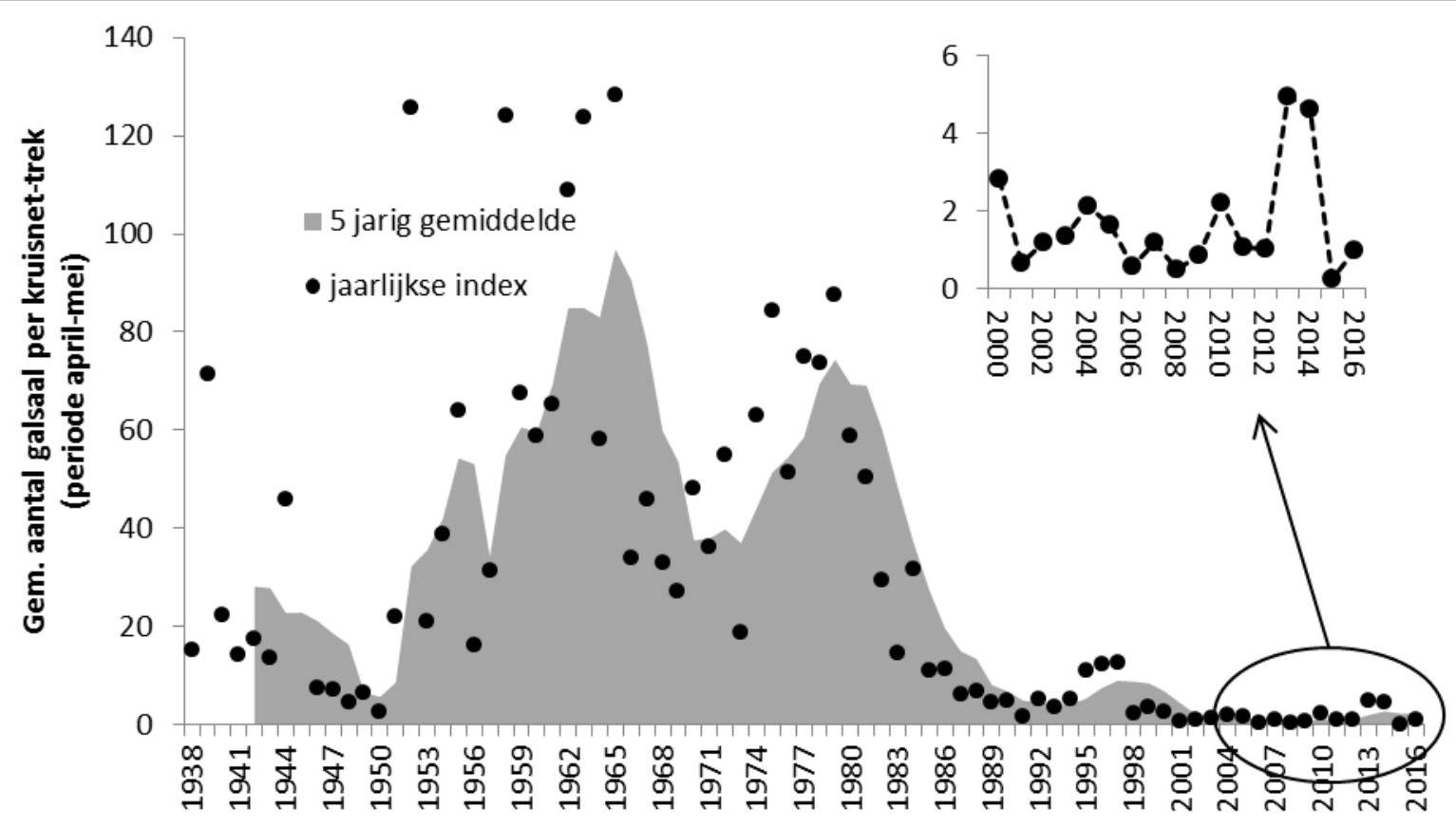

Figuur 2. Trend in de intrek van glasaal bij Den Oever (1983-2016).

\subsection{Trend (rode) aal Waddenzee}

Sinds 1960 worden met een fuikbemonstering de vangsten rode aal in de haven bij de Mokbaai, 't Horntje (Texel) door medewerkers van het NIOZ nauwkeurig bijgehouden (Figuur 3). Deze dataset toont ook een duidelijk afname van de rode aal populatie sinds de jaren tachtig, vergelijkbaar met de drastische afname aan glasaal bij Den Oever. De index vertoont geen tekenen van herstel.

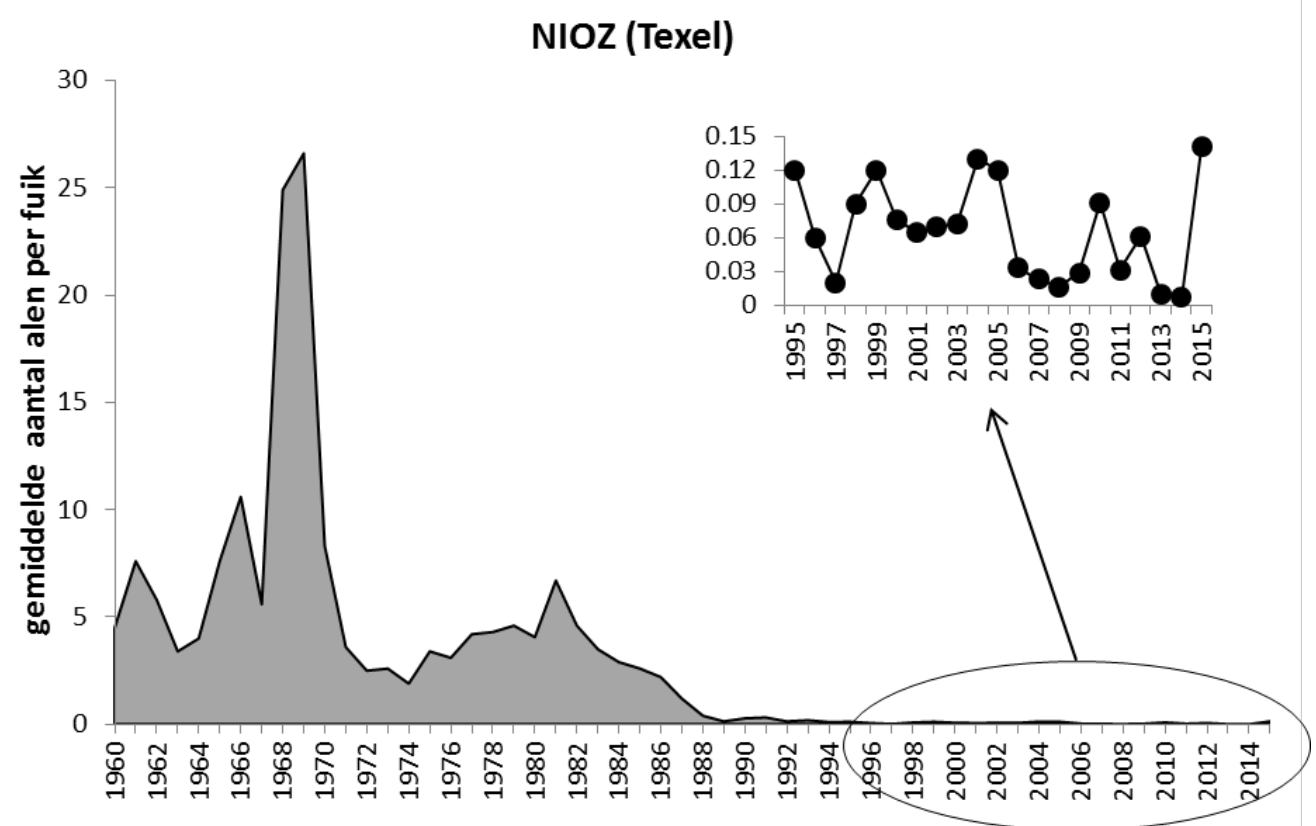

Figuur 3. Trend in de hoeveelheden rode aal in de NIOZ fuik per jaar (1960-2015) (Bron: Van der Meer et al., 2011, Van der Meer pers. com.). 


\subsection{Trend (rode) aal IJ sselmeer/Markermeer}

De bestandsopname met de electrostramienkor toont zowel in het IJsselmeer sinds 2000 als het Markermeer sinds 1990 een scherpe afname van (rode) aal (Figuur 4).

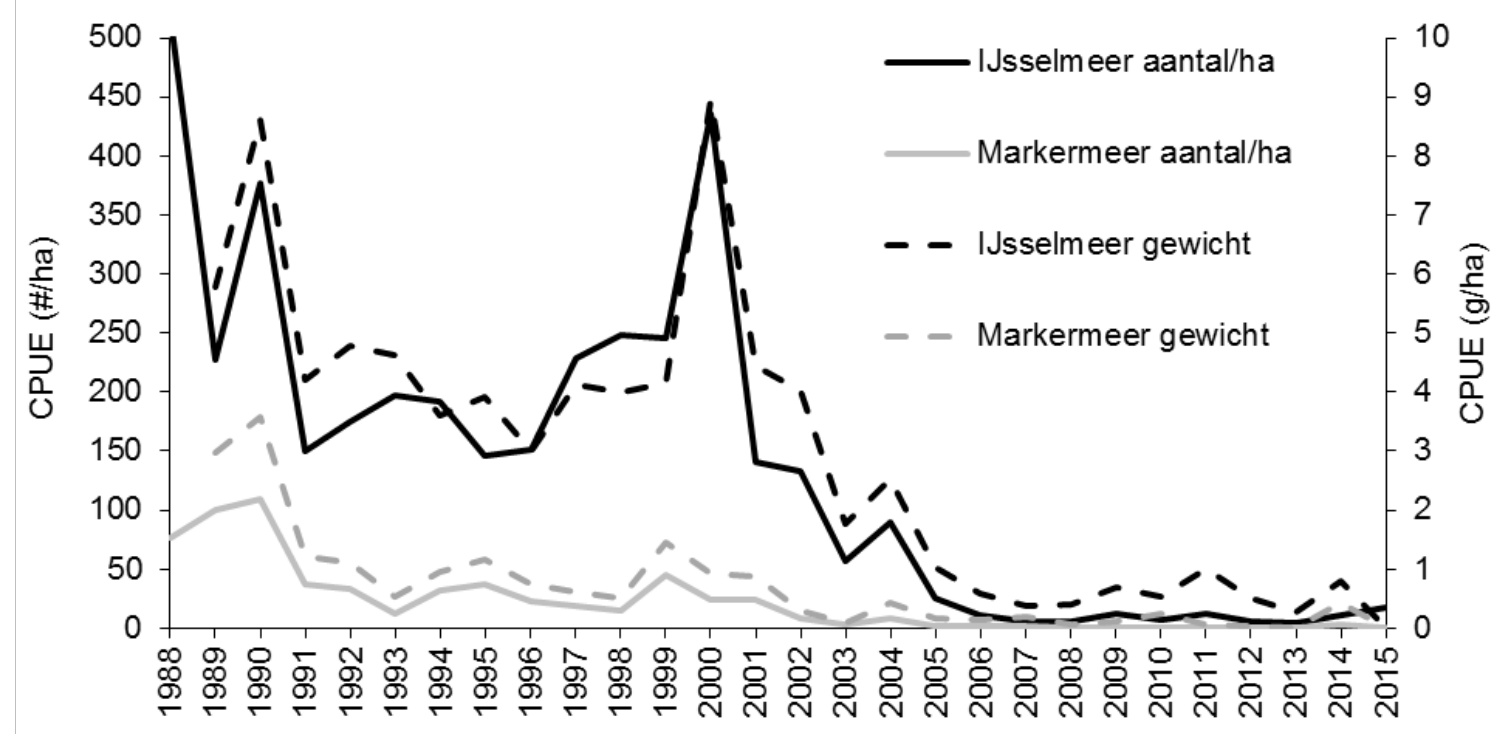

Figuur 4. Trend in de aantallen (linker-as) (doorgetrokken lijnen) en gewicht (rechter-as) (gestreepte lijnen) per ha (rode) aal in het IJ sselmeer en Markermeer per jaar op basis van de vangst met de electrostramienkor. CPUE $=$ catch per unit effort. 


\subsection{Trend schieraal}

Schieraal over de dijk

Sinds 2011 worden bij een aantal gemalen in Zeeland, Noord-Holland en Friesland schieralen geassisteerd bij het passeren van de migratieknelpunten (DUPAN "Paling over de dijk" initiatieven). In 2011, 2012, 2013, 2014 en 2015 werd respectievelijk “bruto" 0.5, 4.6, 9.3 en 3.9 en 6 ton schieraal gevangen en vervolgens over de geselecteerde knelpunten gezet (Figuur 5). Echter een deel van de schieraal had volgens Winter et al. (2013) mogelijk ook zonder assistentie het migratieknelpunt kunnen passeren. Gebruikmakend van de verwachte sterfte (Bierman et al. 2012; Winter et al. 2013) tijdens het passeren van de geselecteerde migratieknelpunten kan een "netto" hoeveelheid verplaatste aal worden berekend. De geschatte sterfte voor aal ligt voor de verschillende gemalen tussen de $11 \%$ en $35 \%$. Deze hoeveelheid extra schieraal die met succes heeft kunnen uittrekken als gevolg van de geleverde inspanning binnen "Paling over de dijk" initiatieven wordt daarom geschat op 0.1 ton in 2011, 0.9 ton in 2012, 2.3 ton in 2013, 0.8 ton in 2014 en 1.1 ton in 2015.

— "bruto" gewicht verplaatste schieraal

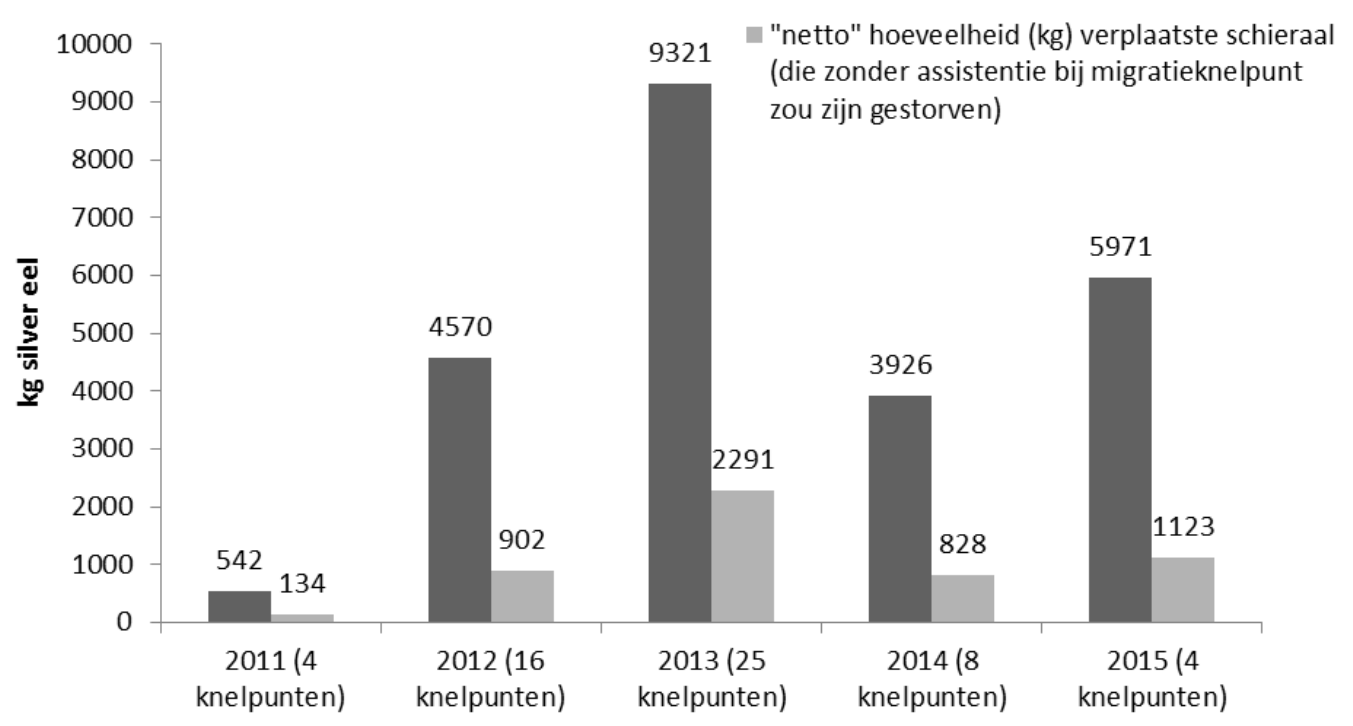

Figuur 5. Overzicht van de "bruto" en "netto" hoeveelheden aal die in 2011-2015 bij diverse knelpunten "over de dijk" zijn gezet (geassisteerde migratie).

\subsection{Trend aalvangsten beroepsvisserij}

De visserij op aal in Nederland vindt plaats in meren, rivieren, kanalen en kustwateren, met de grootste concentraties in de wateren in de lagere delen van ons land. De visserij op aal in Nederland was tot voor kort nauwelijks gedocumenteerd. Invoering van de Europese Aalverordening en het Nederlandse Aal Beheersplan heeft de situatie echter snel verbeterd. De eerste stap is gezet met de invoering van de verplichte vangstregistratie voor aalvissers per $1 / 1 / 2010$. Een nadeel van deze registratie was dat rode aal en schieraal vangsten gecombineerd werden geregistreerd en dat vistuig en visserijinspanning niet werden gedocumenteerd. Het Ministerie van EZ heeft per 1/1/2012 de visserijinspanning opgenomen in de verplichte digitale vangstregistratie. Een overzicht van de wekelijkse inspanning die wordt geleverd door beroepsvissers is te zien in Figuur 6. 

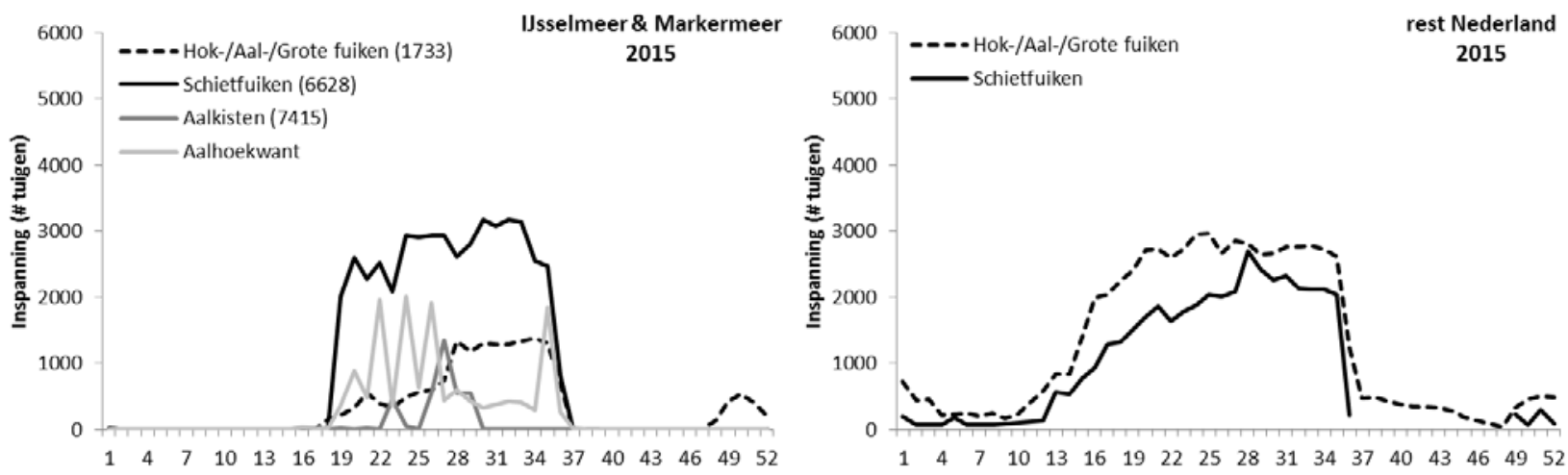

Figuur 6. Overzicht van de wekelijkse inzet van verschillende vistuigen door beroepsvissers in 2015 in IJ sselmeer en Markermeer (links) en rest van Nederland (rechts). De maximale wekelijkse inzet aan tuigen (merkjes) in het IJsselmeer \& Markermeer staat tussen haakjes achter elk type tuig (Bron: Min $\mathrm{EZ})$.

Op het IJ sselmeer is het aantal te gebruiken vistuigen gelimiteerd door merkjes (Figuur 7), die aan de vistuigen bevestigd dienen te worden. Dit aantal is in de periode 1970-1985 sterk toegenomen; daarna is het aantal stapsgewijs verminderd. Na de laatste grote beperking in 2006 liggen de aantallen voor de meeste vistuigen nu nog steeds hoger dan in 1970. Alleen voor staande fuiken heeft in de jaren 1970-1980 vrijwel geen groei plaatsgevonden, terwijl later wel reducties zijn doorgevoerd. Daarmee lag het aantal staande fuiken in 2015 een kwart lager dan in 1970. Voor de visserij met hoekwant ligt alleen het maximum aantal hoekwantvissers vast, maar omdat iedere visser zelf mag bepalen met hoeveel "spleten" (een hoekwant met 250 haken) wordt gevist is de daadwerkelijke inspanning niet duidelijk.

Voor alle tuigen geldt dat het tot 2012 onduidelijk was welk deel van de "merkjes" ook daadwerkelijk wekelijks werd ingezet door de beroepsvissers in het IJ sselmeer en Markermeer. Figuur 6 laat zien dat in 2014 niet alle toegestane merkjes ook daadwerkelijk wekelijks zijn ingezet.

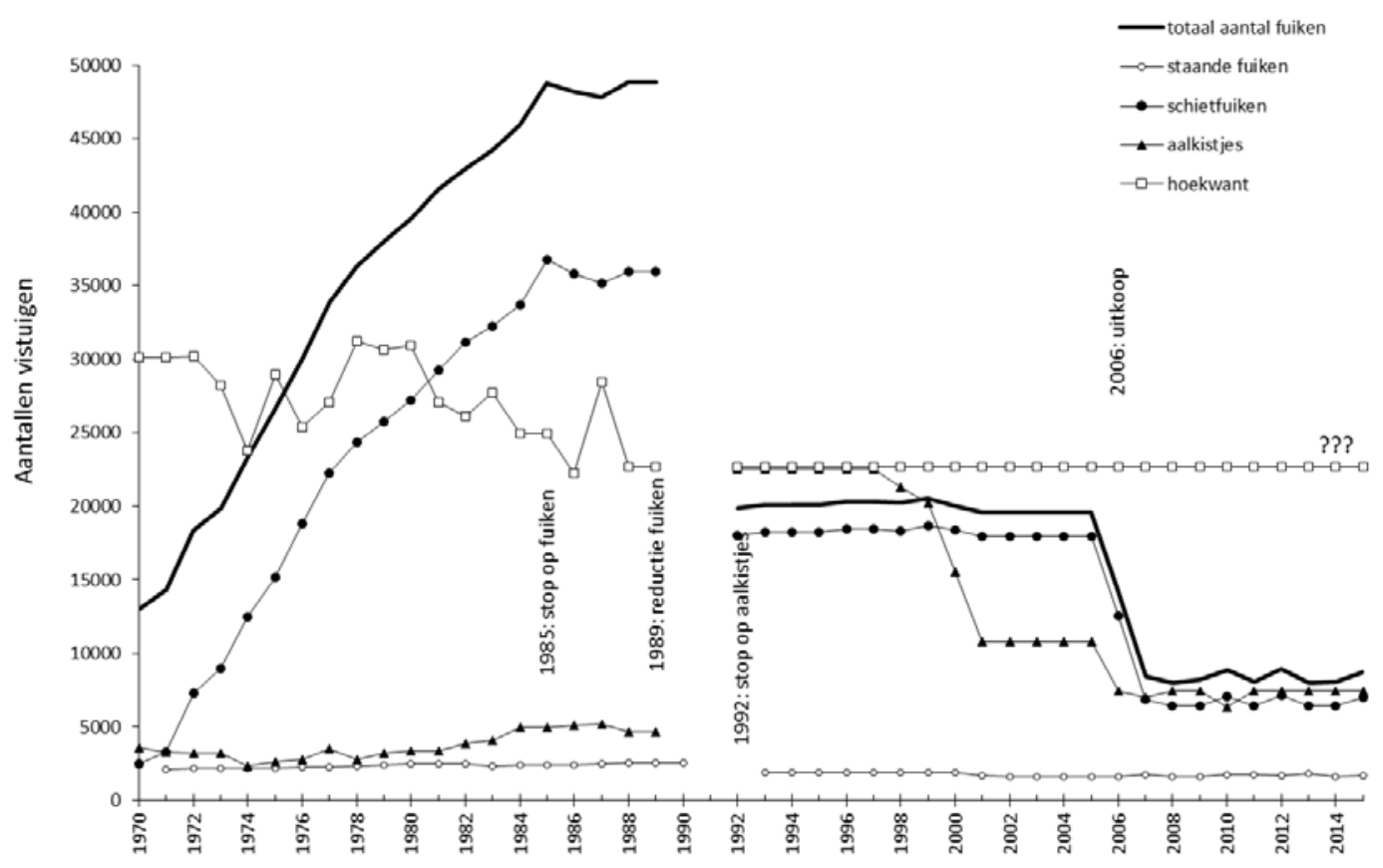

Figuur 7. Trend in de nominale hoeveelheden vistuig binnen de aalvisserij op het IJ sselmeer/Markermeer (Bron: de Leeuw et al., 2006 en Producentenorganisatie IJsselmeer (PO) IJsselmeer). 
Voor de Zuiderzee/IJ sselmeer zijn gegevens beschikbaar over de aanvoer op de afslagen sinds 1880. De aanlandingen van aal uit de Zuiderzee toonden in de periode 1880-1932 een stijging van 300 naar 1000 ton per jaar. Bij de afsluiting van het IJ sselmeer namen de aanlandingen toe tot ca. 2500 ton per jaar, om daarna verder te stijgen tot rond 3500 ton per jaar in de jaren 1940-1955. Sinds 1950 heeft de aanvoer sterk gefluctueerd, maar is wel een gestage daling opgetreden tot minder dan 400 ton per jaar sinds 2000 en 141 ton (EZ: Tabel 1) dan wel 46 ton (PO: Figuur 8) in 2015. Voor het IJ sselmeer/Markermeer valt op dat er behoorlijke verschillen zitten tussen de gegevens afkomstig van PVIS, PO en EZ over de hoeveelheden aal die worden aangeland (Figuur 8 en Tabel 1).

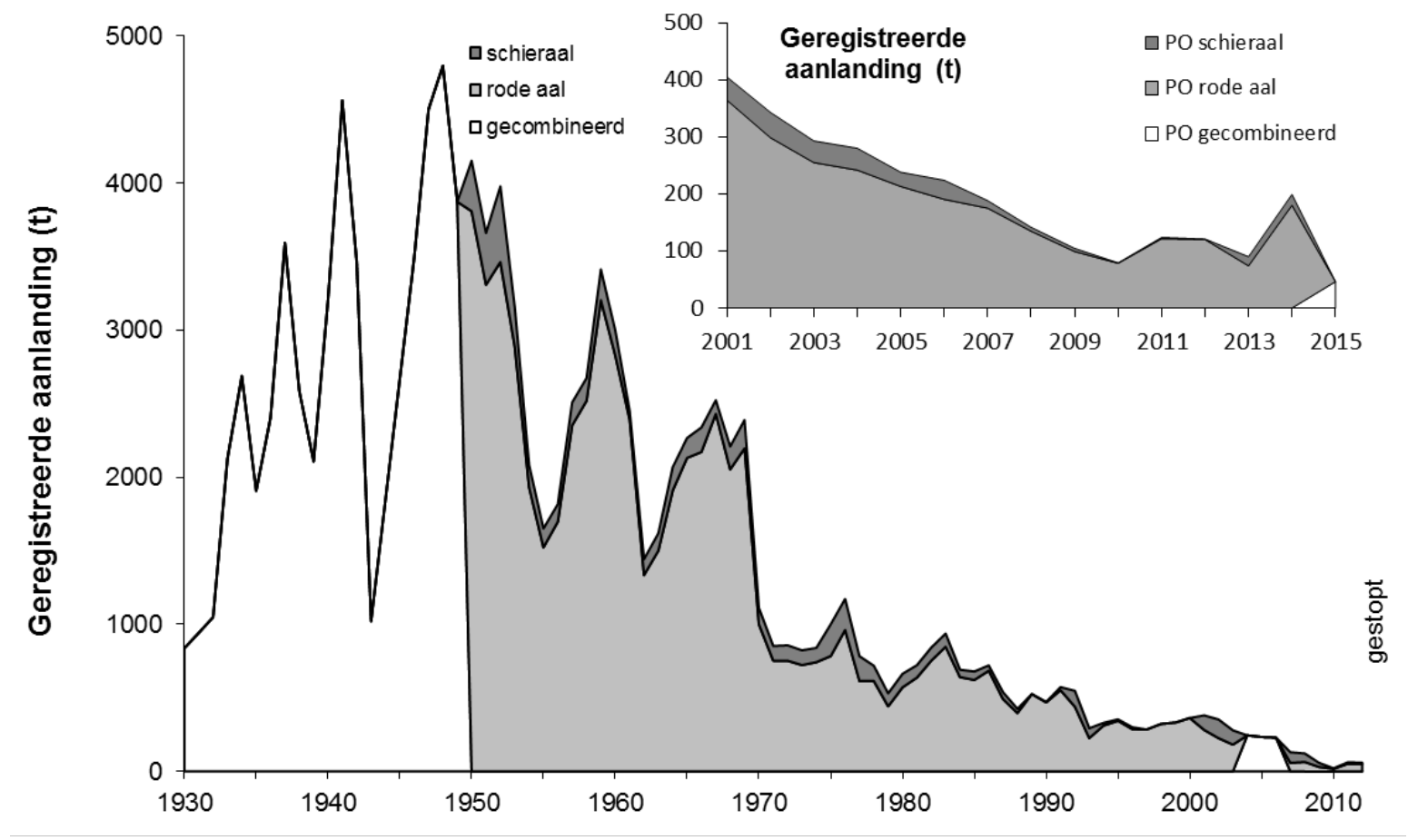

Figuur 8. Trend in de geregistreerde aanlanding van aal op alle IJ sselmeerafslagen (Bron PVIS) en trend in geregistreerde aanlandingen voor het IJ sselmeer en Markermeer door de PO IJ sselmeer (inzet). In 2009 was de aalvisserij gedurende oktober en november gesloten en vanaf 2010 is de visserij gesloten gedurende september, oktober en november.

Tot voor kort waren er geen aanlandingsgegevens van de wateren buiten het IJsselmeer. Op 1 januari 2010 heeft het Ministerie van EZ een verplichte vangstregistratie ingevoerd voor alle aalvissers op de binnenwateren. De wekelijkse aalvangsten (rode aal en schieraal gecombineerd) worden per VBCgebied opgenomen in de database van EZ (Tabel 1).

Tabel 1. Aanlanding van aal (ton) door de beroepsvisserij in Nederland 2010-2015 (Bron: PO en EZ).

\begin{tabular}{ccccc}
\hline & \multicolumn{2}{c}{ IJsselmeer/ Markermeer } & Andere gebieden & \multicolumn{2}{c}{ Totaal NL } \\
\hline & PO & EZ & EZ & EZ \\
\hline 2010 & 79 & 128 & 324 & 452 \\
\hline 2011 & 124 & 179 & 188 & 367 \\
\hline 2012 & 121 & 168 & 182 & 350 \\
\hline 2013 & 90 & 144 & 171 & 315 \\
\hline 2014 & 199 & 163 & 153 & 317 \\
\hline 2015 & 46 & 141 & 157 & 298 \\
\hline
\end{tabular}




\subsection{Trend aalvangsten recreatieve visserij}

In 2009 is het Recreatieve Visserij onderzoeksproject van start gegaan. In december 2009, 2011 en 2013 zijn 50000 huishoudens benaderd tijdens een Screening Survey om vast te stellen hoeveel recreatieve vissers er zijn in Nederland. Dit waren er 1,7 miljoen in 2009, 1,4 in 2011 en 1,3 in 2013. In zowel 2010 en 2012 zijn 2500 recreatieve vissers geselecteerd om deel te nemen aan een logboekprogramma voor een periode van 12 maanden om inzicht te krijgen in hoeveelheden gevangen aal en andere vissoorten. In 2012 is het aantal onttrokken alen grofweg gelijk gebleven maar is het aantal gevangen en teruggezette alen toegenomen in vergelijking tot 2010 (Tabel 3).

Tabel 3. Overzicht van de aalvangsten door recreatieve vissers in de Nederlandse binnenwateren en kustwateren (Van der Hammen \& de Graaf 2015). Totale vangst is de optelsom van kolommen A en B. Kolom A: Onttrokken = gevangen en niet terug gezet. Kolom B: teruggezet. Kolom C: \% onttrokken is het percentage van het totaal aantal gevangen alen ( $A+B$ : onttrokken + teruggezet).

\begin{tabular}{|c|c|c|c|c|c|c|}
\hline & \multicolumn{6}{|c|}{2010} \\
\hline & A. & onttrokken & B. & teruggezet & C. & $\%$ onttrokken \\
\hline Aal alle wateren & & 466000 & & 967000 & & $32 \%$ \\
\hline Aal Binnenwater & & 294000 & & 862000 & & $25 \%$ \\
\hline \multirow[t]{3}{*}{ Aal Zee- en kustwater } & & 172000 & & 114000 & & $69 \%$ \\
\hline & & & & 2012 & & \\
\hline & A. & onttrokken & B. & teruggezet & C. & $\%$ onttrokken \\
\hline Aal alle wateren & & 404000 & & 1584000 & & $20 \%$ \\
\hline Aal Binnenwater & & 313000 & & 1517000 & & $17 \%$ \\
\hline Aal Zee- en kustwater & & 91000 & & 67000 & & $58 \%$ \\
\hline
\end{tabular}




\subsection{Trend aquacultuur}

De grootste hoeveelheid aal ( $29 \%$ ) in Nederland voor consumptie wordt geproduceerd in intensieve kwekerijen. Hierin wordt in het wild gevangen glasaal geïmporteerd uit voornamelijk Frankrijk en Spanje (Tabel 4) en opgekweekt onder gecontroleerde omstandigheden.

Tabel 4. Herkomst van de geïmporteerde, wild gevangen glasaal in de Nederlandse aquacultuur sector (Bron: DUPAN).

\begin{tabular}{|c|c|c|c|c|}
\hline Seizoen & Frankrijk & Spanje & Engeland & Totaal (kg) \\
\hline $2010 / 2011$ & 4725 & 1890 & 135 & 6750 \\
\hline $2011 / 2012$ & 5325 & 1350 & 100 & 6775 \\
\hline $2012 / 2013$ & 5500 & 650 & 550 & 6700 \\
\hline $2013 / 2014$ & 3400 & 250 & 1250 & 4900 \\
\hline $2014 / 2015$ & 4400 & 500 & 300 & 5200 \\
\hline $2015 / 2016$ & 5200 & 0 & 'Paar honderd kg' & $5500 *$ \\
\hline
\end{tabular}

*ervan uitgaande dat 'een paar honderd' ca $300 \mathrm{~kg}$ is.

De totale productie is sinds de start in 1985 gestegen tot meer dan 4000 ton in 2005. Tussen 2005 en 2010 is de productie gedaald tot 2000 ton en tussen 2010 en 2015 is de productie eerst gestegen en toen weer gedaald tot het niveau van 2010. In 2015 is ongeveer 2000 ton aal geproduceerd (Figuur 9). Kunstmatige voortplanting van de aal voor commerciële doeleinden is tot op heden niet mogelijk. Wel is in 2016 aal in het laboratorium tot voorplanting gebracht bij het 'Eel Reproduction Innovation Centre' (EELRIC), een samenwerking tussen de WUR en DUPAN ${ }^{1}$.

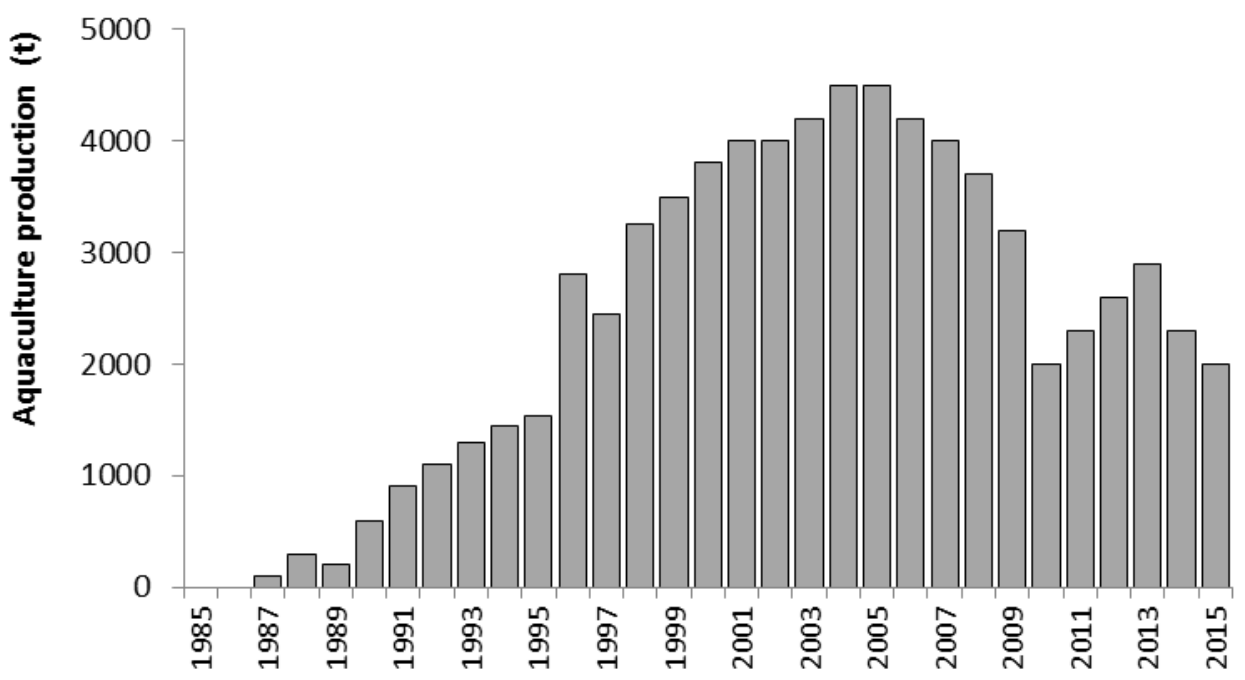

Figuur 9. Trend in de hoeveelheden aal die worden geproduceerd door de aquacultuur sector.

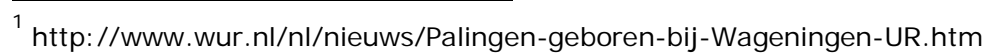




\subsection{Trend uitzet glasaal en pootaal}

Sinds de jaren '20 van de vorige eeuw is glasaal uit de omgeving van de Golf van Biskaje aangekocht en uitgezet in de Nederlandse binnenwateren (Figuur 11). De uitzet van glasaal heeft waarschijnlijk min of meer gelijke tred gehouden met de natuurlijke intrek, zoals te zien is aan de scherpe daling in de jaren '80. In 2009 werd nog maar circa 0.3 miljoen glasalen uitgezet, in 2015 waren dit er circa 3.3 miljoen (Tabel 3). Daarnaast is pootaal uitgezet ( 0.5 miljoen stuks) (Tabel 3). Deze pootaal werd tot begin jaren '80 voornamelijk gevangen in de Nederlandse kustzone en/of de benedenloop van de rivieren. In recente jaren heeft de uitzet van gekweekte aal (opgekweekt uit glasaal van Frankrijk en Engeland) de overhand (zie schema in Figuur 10). Sinds de opheffing van de OVB in 2005, wordt de aanvoer van glasaal en pootaal voor uitzet niet meer centraal geregistreerd. De latere cijfers zijn gebaseerd op opgave van de belangrijkste initiatiefnemers, maar mogelijk zijn kleinere partijen gemist.

Tussen 2010 en 2013 heeft het Productschap Vis (PVIS) de uitzet van de door het Ministerie van EZ aangekochte glasaal gecoördineerd ter bevordering van het herstel van de aalstand. Vanaf 2014 (opheffing PVIS) is dit overgenomen door DUPAN. Net als in voorgaande jaren is de door EZ aangekochte glasaal in 2016 vooral uitgezet in gebieden waar weliswaar vrije uittrek mogelijkheden zijn voor schieraal, maar waar ook de beroepsvisserij actief is. Er is (internationaal) verdeeldheid over het nut van de uitzet van geïmporteerde, in het wild gevangen, glasaal als maatregel voor het herstel van de aalstand. In het advies van ICES uit 2010 ten aanzien van het beheer van aal staat: "Given the current record-low abundance of glass eels, ICES reiterates its concern that glass eel stocking programs are unlikely to contribute to the recovery of the European eel stock. This is because (a) there is no surplus anywhere of glass eel to be redistributed to other areas and (b) there is evidence that stocked/translocated eels experience impairment of their navigational abilities." In het 2015 advies van ICES staat ten aanzien van het uitzetten van glasaal: "There is evidence that translocated and stocked eel can contribute to yellow and silver eel production in recipient waters, but evidence of contribution to actual spawning is limited by the general lack of knowledge of the spawning of any eel. Internationally coordinated research is required to determine the net benefit of restocking on the overall population, including carrying capacity estimates of glass eel source estuaries as well as detailed mortality estimates at each step of the stocking process. When stocking to increase silver eel escapement and thus aid stock recovery, an estimation of the prospective net benefit should be made prior to any stocking activity. Where eel are translocated and stocked, measures should be taken to evaluate their fate and their contribution to silver eel escapement. Such measures could be batch marking of eel to distinguish groups recovered in later surveys (e.g. recent Swedish, French, and UK marking programmes), or implementing tracking studies of eel of known origin. Marking programmes should be regionally coordinated." Met andere woorden; het uitzetten van glasaal ten behoeve van het herstel van de aalstand heeft alleen nut als de productie schieraal per glasaal hoger is in het gebied van uitzet dan in het gebied van herkomst. Het is op dit moment onduidelijk of het uitzetten van glasaal in Nederland een netto positief effect heeft op de aalstand.

Het merken van alle uitgezette glasaal, zoals in sommige andere landen gebruikelijk is, is een goede manier om beter inzicht te krijgen in het lot van de uitgezette glasaal en om mogelijk beter inzicht te krijgen in de vraag of de huidige uitzet van glasaal een netto positieve of negatieve bijdrage levert aan het herstel van de Europese aalstand. Daarnaast geeft het mogelijk een indruk van de natuurlijke intrek van glasaal.

Tabel 2. Overzicht van het gebruik van geïmporteerde, in het wild gevangen glasaal (in kg per jaar) in Nederland.

\begin{tabular}{rrrrrrrrrr}
\hline glasaal & $\mathbf{2 0 0 9}$ & $\mathbf{2 0 1 0}$ & $\mathbf{2 0 1 1}$ & $\mathbf{2 0 1 2}$ & $\mathbf{2 0 1 3}$ & $\mathbf{2 0 1 4}$ & $\mathbf{2 0 1 5}$ & $\mathbf{2 0 1 6}$ \\
\hline Gevangen in commerciële visserij & 0 & 0 & 0 & 0 & 0 & 0 & 0 & 0 \\
\hline Gebruikt voor uitzet & 100 & 904 & 244 & 766 & 630 & 2.460 & 278 & 950 \\
\hline Gebruikt voor aquacultuur & $?$ & $?$ & 6.750 & 6.775 & 6.700 & 4.900 & 5.200 & 5.500 \\
\hline Directe consumptie & 0 & 0 & 0 & 0 & 0 & 0 & 0 & 0 \\
\hline Mortaliteit & $?$ & $?$ & $?$ & $?$ & $?$ & $?$ & $?$ \\
\hline
\end{tabular}




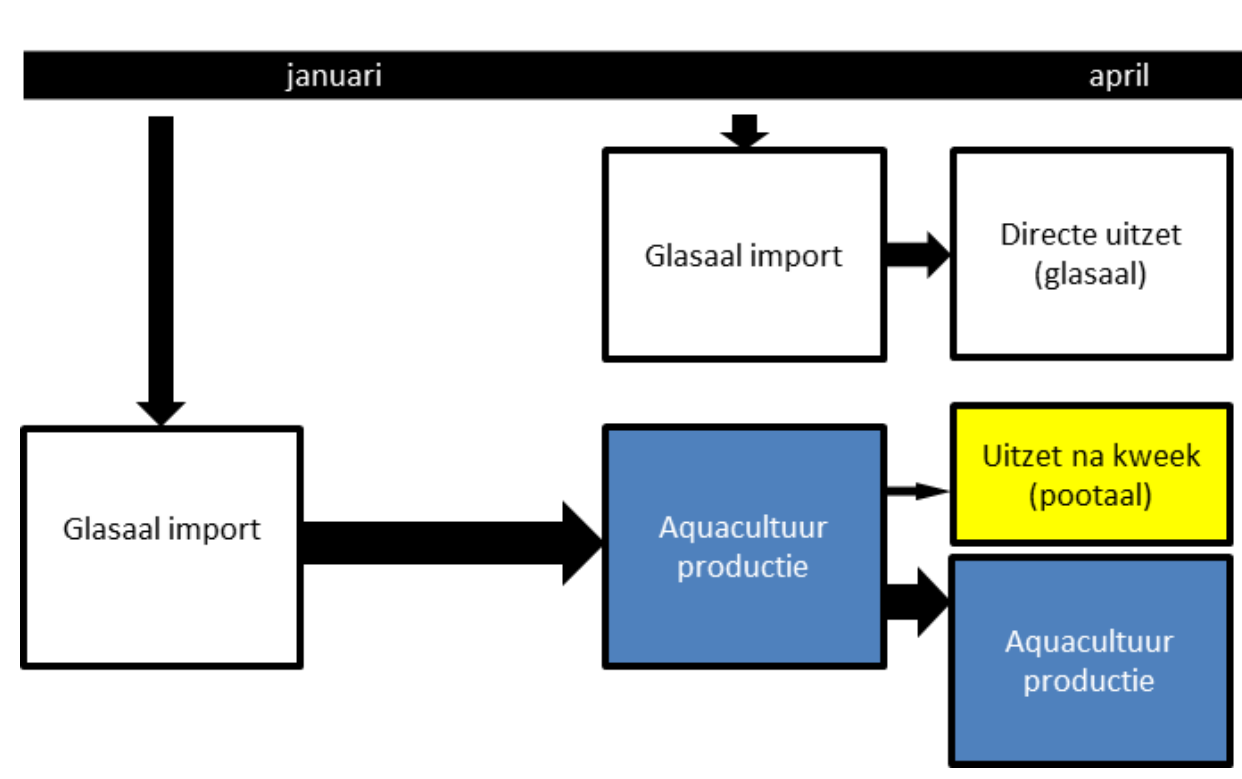

Figuur 10. Schematisch overzicht van de bestemming van geïmporteerde glasaal. Glasaal geïmporteerd in de winter voor aquacultuur wordt gedeeltelijk als pootaal uitgezet. Glasaal geïmporteerd in het voorjaar wordt direct uitgezet. 


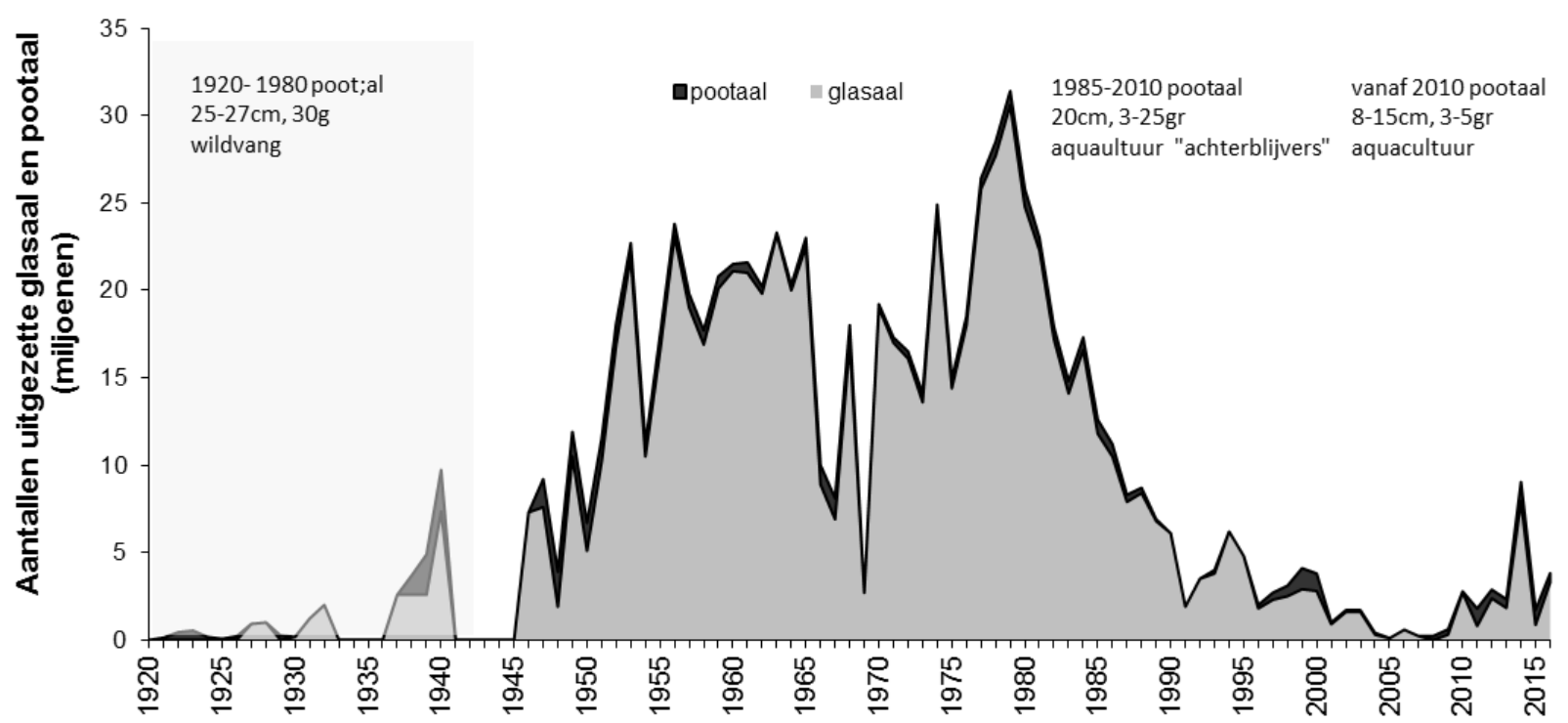

Figuur 11. Overzicht van de Nederlandse uitzet van glasaal en pootaal in miljoenen stuks per jaar (1920-2016). De gegevens van voor 1940 zijn slechts een indicatie. Het gewicht van de gemiddelde uitgezette pootaal is afgenomen van 30 gram (1920) naar 15 gram (1985) tot 5 gram (2010).

Tabel 3. Overzicht van de in 2016 in Nederland uitgezette glasaal en pootaal (Bron: CvB en DUPAN).

\begin{tabular}{|c|c|c|c|c|c|}
\hline Datum & Locatie & Bron & Kg & Aantal & Aantal/ kg \\
\hline \multicolumn{6}{|l|}{ Glasaal } \\
\hline $17-03-2016$ & Friese Boezem & Frankrijk & 636 & 2.247 .000 & 3533 \\
\hline 29/04/2016 & Friese Boezem & Frankrijk & 134 & 462.000 & 3448 \\
\hline $15 / 04 / 2016$ & Veerse Meer & Frankrijk & 79 & 252.000 & 3190 \\
\hline $15 / 04 / 2016$ & Otheense Kreek en Braakman & Frankrijk & 26 & 81.000 & 3115 \\
\hline$?$ & Zeeland & $?$ & 15 & 52.632 & $3509^{(1)}$ \\
\hline$?$ & Zuid-Holland & $?$ & 60 & 210.526 & $3509^{(1)}$ \\
\hline TOTAAL & & & 950 & 3.305 .158 & \\
\hline \multicolumn{6}{|l|}{ Pootaal } \\
\hline $17 / 06 / 2016$ & Grevelingen & Frankrijk & 1.432 & 490.000 & 342 \\
\hline $11 / 06 / 2016$ & Kampen $^{(2)}$ & Frankrijk & 96 & 27.000 & 281 \\
\hline TOTAAL & & & 1.528 & 517.000 & \\
\hline TOTAAL glasaal+pootaal & & & 2.478 & 3.822 .158 & \\
\hline
\end{tabular}

1) uitgaande van $0.285 \mathrm{~g} / \mathrm{aal}$ (DUPAN)

2) bron: http://www.rtvoost.nl/tag/paling?nid=246329 


\subsection{Trend vervuiling}

In het kader van de monitoring van voedselkwaliteit, zijn sinds eind jaren 1970 de gehaltes van vervuilende stoffen in aal bepaald. Na de sterke vervuiling in de jaren voor 1970, is een gestage daling in de gehaltes van PCB's en dioxines in aal waargenomen. In Figuur 11 wordt een enkel voorbeeld (trends in PCB 153) getoond; PCB 153 is een goede indicator voor de andere PCB's.

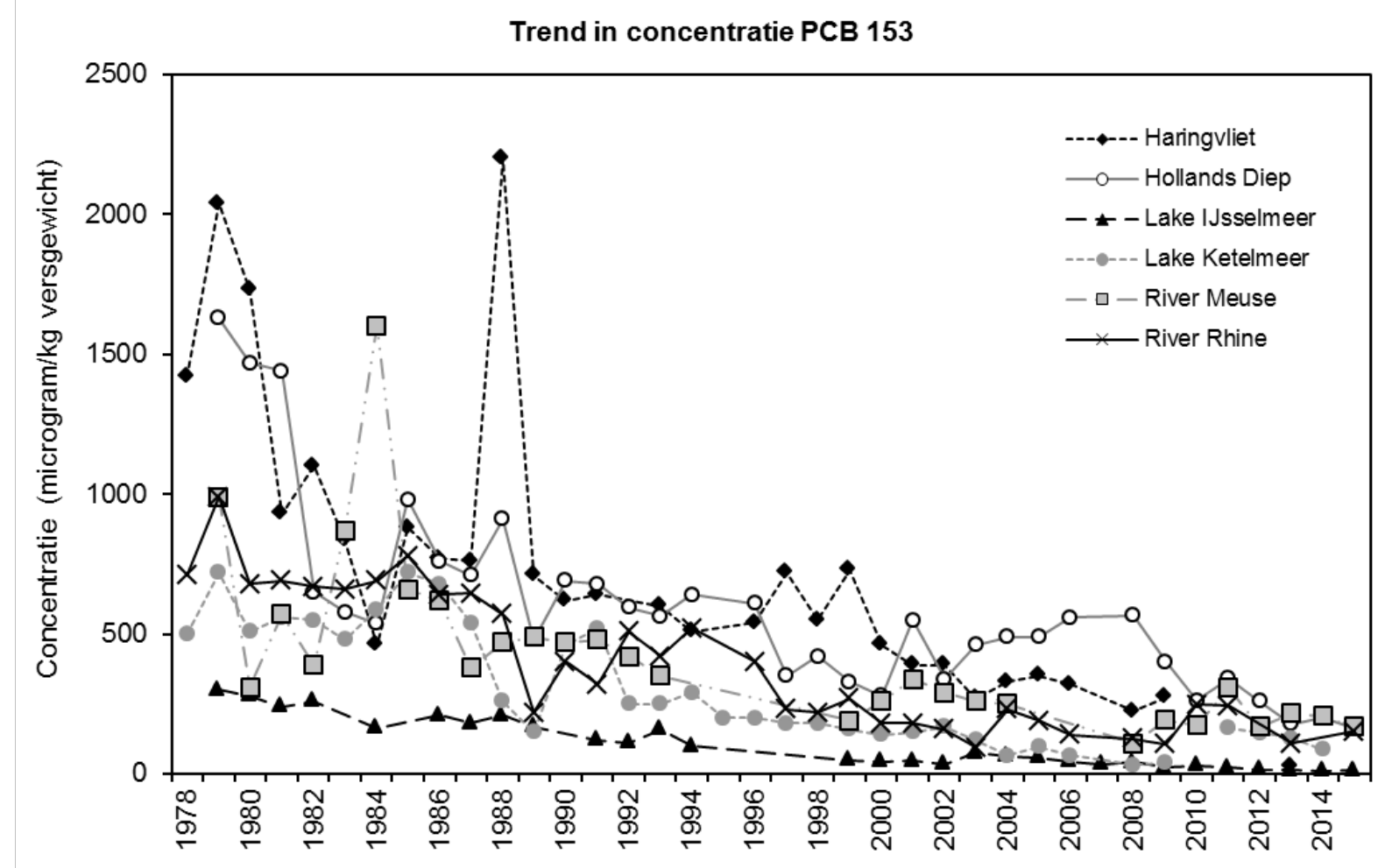

Figuur 12. Trends in PCB 153 in rode aal (1978-2015). Elk punt is de gemiddelde concentratie van PCB 153 van 25 alen van 20 tot $30 \mathrm{~cm}$, of minder alen dan 25 stuks als er minder aal beschikbaar was op die locatie. 


\subsection{Trend zwemblaasparasiet}

De zwemblaasparasiet Anguillicoloides crassus is afkomstig uit Zuidoost Azië en sinds begin jaren ' 80 komt de parasiet voor in Nederlandse wilde aal. Bemonstering van aal laat zien dat het percentage geïnfecteerde aal in 2015 tussen circa 18-35\% lag, afhankelijk van de locatie (Tabel 4). Het percentage geïnfecteerde aal lijkt stabiel te blijven sinds de jaren '80 in alle onderzochte gebieden. In 2015 lijkt het percentage lager iets lager dan de jaren ervoor.

Tabel 4. Overzicht van de aanwezigheid van zwemblaasparasiet Anguillicoloides crassus in aal.

\begin{tabular}{|c|c|c|c|c|c|c|c|c|}
\hline & FRIESLAND & & IJSSELMEER & & MARKERMEER & & $\begin{array}{l}\text { REST } \\
\text { NL }\end{array}$ & \\
\hline & $\mathrm{N}$ aal & $\begin{array}{l}\% \\
\text { geïnfec- } \\
\text { teerd }\end{array}$ & $\mathrm{N}$ aal & $\begin{array}{l}\% \\
\text { geïnfec- } \\
\text { teerd }\end{array}$ & $\mathrm{N}$ aal & $\begin{array}{l}\% \\
\text { geïnfec- } \\
\text { teerd }\end{array}$ & $\mathrm{N}$ aal & $\begin{array}{l}\% \\
\text { geïnfec- } \\
\text { teerd }\end{array}$ \\
\hline 2010 & 534 & $46 \%$ & 390 & $49 \%$ & 225 & $48 \%$ & 511 & $50 \%$ \\
\hline 2011 & 107 & $37 \%$ & 293 & $43 \%$ & 104 & $34 \%$ & 583 & $40 \%$ \\
\hline 2012 & 133 & $33 \%$ & 320 & $52 \%$ & 253 & $38 \%$ & 529 & $35 \%$ \\
\hline 2013 & 17 & $47 \%$ & 14 & $50 \%$ & 93 & $43 \%$ & 428 & $44 \%$ \\
\hline 2014 & 49 & $63 \%$ & 202 & $50 \%$ & 46 & $26 \%$ & 321 & $40 \%$ \\
\hline 2015 & 62 & $18 \%$ & 267 & $35 \%$ & $\mathrm{NC}$ & & 297 & $28 \%$ \\
\hline
\end{tabular}




\section{Introduction}

The English part of this report follows the format provided by ICES WGEEL.

\section{$2.1 \quad$ Authors}

Dr. Martin de Graaf, IMARES (Institute for Marine Resources \& Ecosystem Studies), IJ muiden, The Netherlands. Tel: 00-31-317-486826. martin.degraaf@wur.nl

Dr. Oscar Bos, IMARES (Institute for Marine Resources \& Ecosystem Studies), Den Helder, The Netherlands. Tel: 00-31-317-487071. oscar.bos@wur.nl

\subsection{Reporting Period}

This report contains data up to 2015 and some provisional data for 2016.

\subsection{Contributors to the report}

Ingeborg de Boois (IMARES: survey data coastal areas), Mennobart van Eerden (Rijkswaterstaat Waterdienst; cormorant breedings pairs IJ sselmeer area), Ben Griffioen (IMARES; glass eel index); Arjan Heinen (Combinatie van Beroepsvissers; stocking data; silver eel fisheries data), Twan Leijzer (Wageningen Marine Research; parasite infections); Jaap van der Meer (NIOZ; yellow eel data NIOZ fyke), Michiel Kotterman (Wageningen Marine Research; data on contaminants), DUPAN (glass eel stocking data, assisted migration silver eel and eel aquaculture production). 


\subsection{Codes used for circumstances of Nil Return in tables:}

0: $\quad$ Measured data point with an actual zero value (for example when the catch is zero but the effort is >zero).

NP: "Not Pertinent", where the question asked does not apply to the individual case (for example where catch data are absent as there is no fishery or where a habitat type does not exist in an EMU).

NR: “Not Reported", data or activity exist but numbers are not reported to authorities (for example for commercial confidentiality reasons).

NC: "Not Collected", activity / habitat exists but are not collected by authorities (for example where a fishery exists but the catch data are not collected at the relevant level or at all).

ND: "No Data", where there are insufficient data to estimate a derived parameter (for example where there are insufficient data to estimate the stock indicators (biomass and/or mortality)).

Table 1. Units and number of decimal places

\begin{tabular}{lll} 
PARAMETER & UNIT & $\begin{array}{l}\text { DECIMAL PLACES } \\
\text { (MINIMUM) }\end{array}$ \\
& & \\
\hline $\begin{array}{l}\text { Length of glass eel } \\
\text { Length of yellow/silver eel }\end{array}$ & $\mathrm{mm}$ & 0 \\
Age yellow or silver eel & $\mathrm{mm}$ & 0 \\
Age glass eel/on grown & days & 0 \\
Area (EMU scale) & ha & 0 \\
Area (Sub EMU scale) & ha & 0 \\
Weight (individual Glass eel) & $\mathrm{g}$ & 0 \\
Weight (Yellow or silver eel) & $\mathrm{g}$ & 2 \\
Weight (Catch level) GE & $\mathrm{kg}$ & 0 \\
Weight (Catch level) Other & $\mathrm{kg}$ & 0 \\
Site/position & Lat Long units (WGS84) & 0 \\
Biomass (B0 Bbest Bcurrent & $\mathrm{kg}$ & 0 \\
,etc) & & \\
Mortality rate & $\Sigma \mathrm{F}, \Sigma \mathrm{H}, \Sigma$ A per year & 2 \\
Effort & Gear days, gear hours & 0 \\
Language & English & \\
Price & Euros & 0 \\
Distance & Km & 0 \\
Season & Clearly define season & \\
& & \\
& &
\end{tabular}




\section{Overview of the stock and its management}

\subsection{The eel stock and its management}

\subsubsection{Eel Management Units and Eel Management Plans}

The Netherlands consists of 1 EMU coded 'NL_Neth' and there is one Eel Management Plan (EMP) ${ }^{2}$ that was implemented in July 2009 and revised in 2011.

\subsubsection{Management authorities}

The Dutch Ministry of Economic Affairs (PO Box 20401, 2500 EK Den Haag, The Netherlands) is responsible for the conservation of stocks and for the management of all anthropogenic impacts, as well as for the delivery of the Eel Management Plan (EMP).

\subsubsection{Regulations}

\subsubsection{Fisheries}

Fisheries on eel in the Netherlands is regulated by the Dutch Fisheries Act, while protection of eel is regulated under the Dutch Flora and Fauna Act. In summary, the following regulations apply: the minimum catch size is $28 \mathrm{~cm}$, a number of fisheries is closed in the period 1 Sept-30 Nov, all eel caught in 1 Sept-30 Nov have to be released, and since 2011 a number of areas is closed for fisheries due to pollution (dioxins) ${ }^{3}$ (Figure NL. 1).

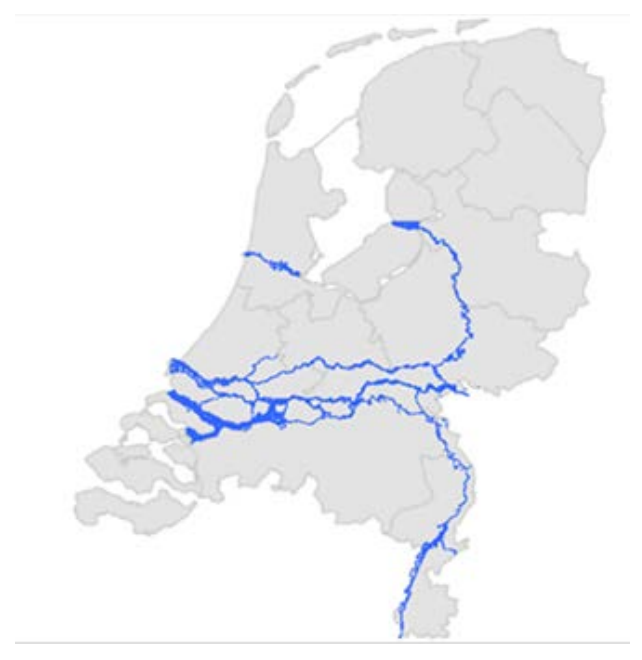

Figure NL. 1. Overview of the areas closed for eel and Chinese mitten crab fishery as of 1 April 2011 (Source: Ministry of Economic Affairs).

2 https://www.rijksoverheid.nl/documenten/rapporten/2009/11/27/aalbeheerplan

3 http://www.sportvisserijnederland.nl/vispas/visserijwet-en-regels/binnenwater/paling.html 


\subsubsection{Management actions}

The management measures taken in the Netherlands in the framework of the EMP are listed in Table NL. A. Overview of all the (un)foreseen measures described in the Dutch Eel Management Plan to be implement to reach the $40 \%$ escapement objective (source: Van de Wolfshaar et al., 2015). Proposed and implemented management measures are listed in Table NL. B.

Table NL. A. Overview of all the (un)foreseen measures described in the Dutch Eel Management Plan to be implement to reach the $40 \%$ escapement objective (source: Van de Wolfshaar et al., 2015).

\begin{tabular}{|c|c|c|c|}
\hline No & Foreseen Measure & Planned implementation & Realised implementation \\
\hline 1 & $\begin{array}{r}\text { Reduction of eel mortality at pumping stations } \\
\text { and other water works; of the } 1800 \text { most } \\
\text { important migration barriers } 900 \text { will be solved } \\
\text { by } 2015 \text { and the remaining } 900 \text { by } 2027\end{array}$ & $2015-2027$ & $2015-2027 a$ \\
\hline 2 & $\begin{array}{r}\text { Reduction of eel mortality at hydro-electric } \\
\text { stations with at least 35\% }\end{array}$ & 2009 & November $2011 b$ \\
\hline 3 & $\begin{array}{l}\text { The establishment of fishery-free zones in } \\
\text { areas that are important for eel migration }\end{array}$ & 2010 & 1 April 2011c \\
\hline 4 & $\begin{array}{r}\text { Release of eel caught (a) at sea and (b) at } \\
\text { inland waters by anglers }\end{array}$ & 2009 & 1 October 2009 \\
\hline 5 & $\begin{array}{r}\text { Ban on recreational fishery in coastal areas } \\
\text { using professional gear }\end{array}$ & 2011 & 1 J anuary $2011 d$ \\
\hline 6 & $\begin{array}{r}\text { Annual closed season from } 1 \text { September to } 1 \\
\text { December }\end{array}$ & 2009 & 1 October 2009 \\
\hline 7 & $\begin{array}{l}\text { Stop the issue of licences for eel snigglers by } \\
\text { the minister of EZ in state owned waters }\end{array}$ & 2009 & 1 May 2009 \\
\hline 8 & $\begin{array}{r}\text { Restocking of glass eel and pre-grown eel from } \\
\text { aquaculture }\end{array}$ & 2009 & Early 2010 \\
\hline \multirow[t]{2}{*}{9} & Research into the artificial propagation of eel & ongoing & EU-project started \\
\hline & & & Unforeseen Measure \\
\hline 10 & Closure eel fishery in contz & lated (PCBs, dioxins) areas & 1 April $2011 \mathrm{e}$ \\
\hline
\end{tabular}

a In agreement with the European Commission changes have been made to the original schedule of solving migration barriers.

b Due to technical difficulties the maximum achievable reduction in mortality by adjusted turbine management is $24 \%$.

c The vast majority of the contaminated areas that were closed for commercial fisheries on 1/4/2011 are the main rivers. These rivers are the most important "high ways" for diadromous species like salmon and eel.

$d$ The use of fykes and long-lines by recreational fishers has been banned in nearly all marine and inland waters waters. The use of gillnets,

however, by recreational fishers is still allowed in a few marine waters.

e On 1 J anuary 2015 the area closed for eel fishery due to contaminants (PCBs, dioxins) was extended. 
Table NL. B. Proposed and implemented management measures. Com fish = commercial fisheries; Rec fish = recreational fisheries; 'Hydropower $\&$ Pumps' includes obstacles; 'Other' refers to indirect measures (e.g. implementing data collection and conducting studies).

\begin{tabular}{|c|c|c|c|c|c|}
\hline EMU code & Action Type & Action & $\begin{array}{l}\text { Life } \\
\text { Stage }\end{array}$ & Planned & Outcome \\
\hline NL_Neth & Com Fish & Closing fishing season & $M$ & EMP & Fulfilled \\
\hline NL_Neth & Com Fish & Introducing fishery-free zones & $M$ & EMP & Fulfilled \\
\hline NL_Neth & Com Fish & $\begin{array}{l}\text { Closure of fishery in contaminated } \\
\text { areas }\end{array}$ & M & After EMP & Fulfilled \\
\hline NL_Neth & Com Fish & Sniggling Ban & $M$ & EMP & Fulfilled \\
\hline NL_Neth & Rec Fish & Eel releasing by anglers & M & EMP & Fulfilled \\
\hline NL_Neth & Rec Fish & $\begin{array}{l}\text { Ban on recreational fishery using } \\
\text { professional gears }\end{array}$ & M & EMP & Fulfilled \\
\hline NL_Neth & Rec Fish & Closing fishing season & M & EMP & Fulfilled \\
\hline NL_Neth & Rec Fish & Sniggling ban & $M$ & EMP & Fulfilled \\
\hline NL_Neth & $\begin{array}{l}\text { Hydropower \& } \\
\text { Pumps }\end{array}$ & Barriers reduction from 2015 & M & EMP & Partially \\
\hline NL_Neth & $\begin{array}{l}\text { Hydropower } \& \\
\text { Pumps }\end{array}$ & $\begin{array}{l}\text { Hydroelectric stations barriers } \\
\text { reduction }\end{array}$ & M & EMP & Partially \\
\hline NL_Neth & Restocking & Stocking with glass eels & M & EMP & Fulfilled \\
\hline
\end{tabular}




\section{$3.2 \quad$ Stock status}

\subsubsection{EMP Progress Report summary table}

\subsubsection{Estimate of $B_{0}$}

Table NL. C. Reference period for B0 (Van de Wolfshaar et al. 2015, p. 72).

\begin{tabular}{ccll}
\hline EMU_code & $\mathrm{B}_{0}(\mathrm{~kg} / \mathrm{ha})$ & Reference time period & $\begin{array}{l}\text { Whether or not changed from value reported last year } \\
(\mathrm{Y} / \mathrm{N})\end{array}$ \\
\hline NL_Neth & 10.400 & 2011 & $\mathrm{~N}$ \\
\hline
\end{tabular}

\subsubsection{Stock indicators and Targets}

Table NL. D. Stock indicators and Target derived from: Van de Wolfshaar et al. 2015, p.72.

\begin{tabular}{|c|c|c|c|c|c|c|c|c|c|}
\hline EMUcode & Indicator & biomass $(\mathrm{T})$ & & Mortá & (rate & & Target & & \\
\hline & $\mathrm{B}_{0}$ & $B_{\text {best }}$ & $\mathrm{B}_{\text {curr }}$ & $\Sigma A$ & $\sum F$ & $\sum \mathrm{H}$ & Source & $\begin{array}{l}\text { Biomass } \\
\text { (t) }\end{array}$ & $\begin{array}{l}\sum A \\
\text { (rate) }\end{array}$ \\
\hline \multirow[t]{3}{*}{ NL_Neth } & 10400 & 1697 & 1057 & 0.47 & 0.35 & 0.12 & EMP & & \\
\hline & & & & & & & EU Reg & 4160 & \\
\hline & & & & & & & WGEEL & & 0.106 \\
\hline
\end{tabular}

\subsubsection{Habitat coverage}

Table NL. E. Habitat coverage derived from Van de Wolfshaar et al. 2015.

\begin{tabular}{|c|c|c|c|c|c|c|c|c|c|c|}
\hline \multirow{2}{*}{$\begin{array}{l}\text { EMU } \\
\text { code }\end{array}$} & \multicolumn{2}{|l|}{ River } & \multicolumn{2}{|l|}{ Lake } & \multicolumn{2}{|c|}{ Estuary } & \multicolumn{2}{|c|}{ Lagoon } & \multicolumn{2}{|l|}{ Coastal } \\
\hline & $\begin{array}{l}\text { Area } \\
\text { (ha) }\end{array}$ & $\begin{array}{l}A^{\prime} d \\
(Y / N)\end{array}$ & $\begin{array}{l}\text { Area } \\
\text { (ha) }\end{array}$ & $\begin{array}{l}A^{\prime} d \\
(Y / N)\end{array}$ & $\begin{array}{l}\text { Area } \\
\text { (ha) }\end{array}$ & $\begin{array}{l}A^{\prime} d \\
(Y / N)\end{array}$ & $\begin{array}{l}\text { Area } \\
\text { (ha) }\end{array}$ & $\begin{array}{l}A^{\prime} d \\
(Y / N)\end{array}$ & $\begin{array}{l}\text { Area } \\
\text { (ha) }\end{array}$ & $\begin{array}{l}A^{\prime} d \\
(Y / N)\end{array}$ \\
\hline NL_Neth & 88,391 & $Y$ & 232,758 & $Y$ & NP & NP & NP & NP & 358,802 & $\mathrm{~N}$ \\
\hline
\end{tabular}

\subsection{Precautionary diagram}

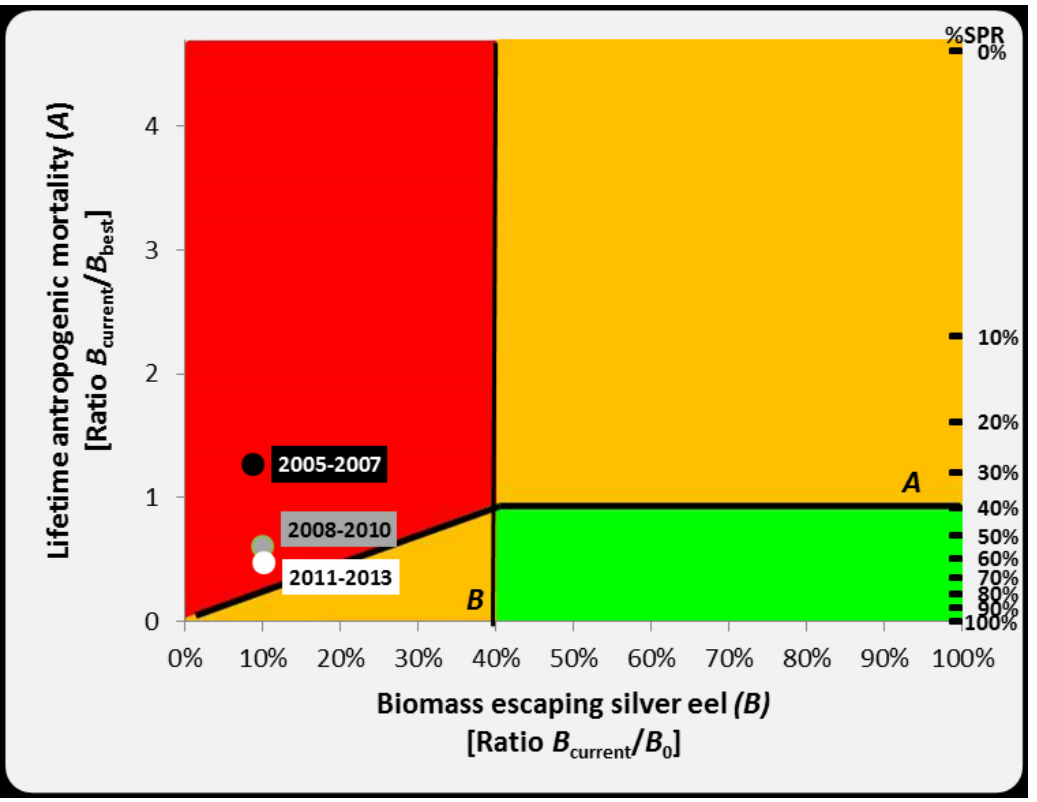

Figure NL. 2. Modified precautionary diagram for the Netherlands EMU (Van de Wolfshaar et al. 2015 after WGEEL 2012), see section 1.3.2 of ICES (2013) for more information. 


\subsection{Significant changes since last report}

There have not been significant changes in the status of the eel across The Netherlands since the Country Report of 2015 (De Graaf \& Bos, 2016). 


\section{$4 \quad$ Impacts on the stock}

Table NL. F. Overview of the assessed impacts per habitat type or for 'All' habitats where the assessment is applied across all relevant habitats. Barriers include habitat loss; indirect impacts are anthropogenic impacts on the ecosystem, but only indirectly on eel (e.g. eutrophication). $A=$ assessed, $\mathrm{MI}=$ not assessed, minor, $\mathrm{MA}=$ not assessed major, $\mathrm{AB}=$ impact absent (Bierman et al. 2012).

\begin{tabular}{|c|c|c|c|c|c|c|c|c|}
\hline EMU CODE & НАВITAT & $\begin{array}{l}\text { FISH } \\
\text { COM }\end{array}$ & $\begin{array}{l}\text { FISH } \\
\text { REC }\end{array}$ & $\begin{array}{l}\text { HYDRO \& } \\
\text { PUMPS }\end{array}$ & BARRIERS & RESTOCKING & PREDATORS & $\begin{array}{l}\text { INDIRECT } \\
\text { IMPACTS }\end{array}$ \\
\hline \multirow[t]{6}{*}{ NL_Neth } & Riv & $A$ & $A$ & $A$ & $A$ & $\mathrm{MI} / \mathrm{MA}$ & $\mathrm{MI} / \mathrm{MA}$ & $\mathrm{Ml} / \mathrm{MA}$ \\
\hline & Lak & A & A & A & A & $\mathrm{MI} / \mathrm{MA}$ & $\mathrm{MI} / \mathrm{MA}$ & $\mathrm{Ml} / \mathrm{MA}$ \\
\hline & Est & NP & NP & NP & NP & NP & NP & NP \\
\hline & Lag & NP & NP & NP & NP & NP & NP & NP \\
\hline & Coa & MI & A & $A B$ & $A B$ & $A B$ & $A B$ & MI \\
\hline & All & & & & & & & \\
\hline
\end{tabular}

Table NL. G. Loss of eel $(\mathrm{kg})$ for each impact per developmental stage. $\mathrm{MI}=$ not assessed, minor; $\mathrm{MA}$ = not assessed major; $A B=$ impact absent. ${ }^{1}$ All eel caught recreationally were assumed to be yellow eel. ${ }^{2}$ Including 6 t mortality of GER/BE silver eel (Bierman et al. 2012).

\begin{tabular}{|c|c|c|c|c|c|c|c|c|}
\hline EMU CODE & StAGE & $\begin{array}{l}\text { FISH } \\
\text { COM }\end{array}$ & $\begin{array}{l}\text { FISH } \\
\text { REC }\end{array}$ & $\begin{array}{l}\text { HYDRO \& } \\
\text { PUMPS }\end{array}$ & BARRIERS & RESTOCKING & PREDATORS & $\begin{array}{l}\text { INDIRECT } \\
\text { IMPACTS }\end{array}$ \\
\hline NL_Neth & Glass & $A B$ & $A B$ & $\mathrm{MI} / \mathrm{MA}$ & $\mathrm{Ml} / \mathrm{MA}$ & MI & $\mathrm{MI} / \mathrm{MA}$ & $\mathrm{Ml} / \mathrm{MA}$ \\
\hline NL_Neth & Yellow & 290 & 100 & $\mathrm{MI} / \mathrm{MA}$ & $\mathrm{MI} / \mathrm{MA}$ & $A B$ & $\mathrm{MI} / \mathrm{MA}$ & $\mathrm{Ml} / \mathrm{MA}$ \\
\hline NL_Neth & Silver & 77 & $\mathrm{AB}^{1}$ & $76^{2}$ & $\mathrm{MI} / \mathrm{MA}$ & $A B$ & $\mathrm{MI} / \mathrm{MA}$ & $\mathrm{Ml} / \mathrm{MA}$ \\
\hline NL_Neth & $\begin{array}{l}\text { Silver } \\
\text { EQ }\end{array}$ & & & & & & & \\
\hline
\end{tabular}

${ }^{1}$ All eel caught recreationally were assumed to be yellow eel.

${ }^{2}$ Including 6 t mortality of GER/BE silver eel.

\subsection{Fisheries}

\subsubsection{General information}

Eel fisheries in the Netherlands occur in coastal waters, estuaries, larger and smaller lakes, rivers, polders, etc. Management of eel stock and fisheries has been an integral part of the long tradition in manipulating water courses (polder construction, river straightening, ditches and canals, etc.). Governmental control of the fishery is restricted to on the one hand a set of general rules (gear restrictions, size restrictions, for course fish: closed seasons), and on the other hand site-specific licensing. Since $1 / 1 / 2010$ there is a general registration of landings, whereas a general registration of fishing efforts has not yet been implemented. In recent years, licensees in state-owned waters are obliged to participate in so-called Fish Stock Management Committees [ 'Visstand Beheer Commissies' VBC], in which commercial fisheries, sports fisheries and water managers are represented. The VBC is responsible for the development of a regional Fish Stock Management Plan. The Management Plans are currently not subject to general objectives or quality criteria. The future of VBC and their role in fish stock management is under debate.

Until April 2011 the total Dutch fresh water fishery on eel involved approx. 200 companies, with an estimated total catch of nearly 442 tonnes of eel in 2010. However, on 1 April 2011 a large part of the fishery was closed due to high PCB-levels in the eel (Fig. NL.1). This closure has affected about 50 fishing companies catching 170 tonnes of eel in 2010, roughly a third of the annual landings of inland waters in the Netherlands. 


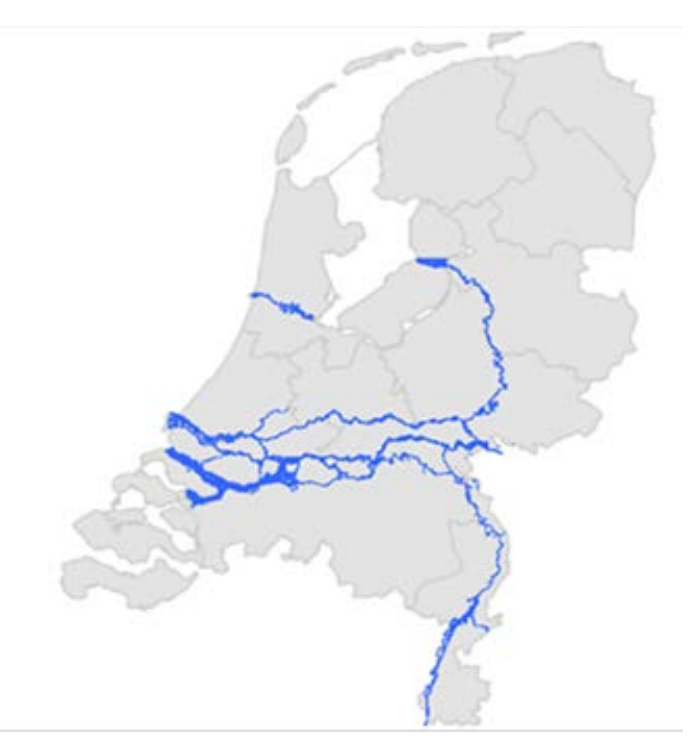

Figure NL. 3. Overview of the areas closed for eel and Chinese mitten crab fishery as of 1 April 2011 (Source: Ministry of Economic Affairs).

\subsubsection{Glass eel}

There is no fishing on glass eel.

\subsubsection{Yellow eel}

\subsection{Commercial}

No reliable long term time series of yellow eel landing exist; total landings of yellow and silver eel combined have been reported.

Statistics from the auctions around Lake IJ sselmeer were kept by the Ministry of Economic Affairs (Ministry of EZ, previously Ministry of LNV) until 1994; since then and until 2012 statistics were kept by the Fish Board (PVis; Table NL. H; Figure NL. 4, main graph). These statistics are broken down by species, month, harbour and main fishing gear. The quality of this information deteriorated considerably over the past decades, due to misclassification of gears, and the trading of eel from areas other than Lake IJ sselmeer and Laker Markermeer at the IJ sselmeer auctions. In the data from auctions around Lake IJ sselmeer yellow and silver eel were reported separately, but data from recent decades (from early 1990s onwards) is unreliable: yellow eel from eel boxes and silver eel from all gears have been combined (see section NL.3.1.5.2.1 for further details).

In addition, the fishers organisation (PO IJ sselmeer) has kept records of the catches of their associated fishers ( $>90 \%$ of the fishers active in the IJ sselmeer area) from 2001 onwards (Figure NL. 4, inserted graph).

An obligatory catch registration system was introduced in the Netherlands in January 2010 by the Ministry of Economic Affairs (Ministry of EZ). Weekly catches of eel have been reported, but yellow eel and silver eel catches are combined in this program and no information on effort and gears have been reported. Information from this registration system is reported in section NL. 3.1.5.2.1. 
Table NL. H. Landings of yellow eel and silver eel combined in tons by year, from the auctions around Lake IJ sselmeer, Rhine RBD. Only landings recorded at the auctions are included; other landings are assumed to represent a minor and constant fraction. Figures in italics (since 1995) are suspect, due to misclassification of catches and trade from areas outside Lake IJ sselmeer at the IJ sselmeer auctions. Source Ministry of Economic Affairs (EZ; 1900-1994), Productschap Vis (PVIS; 1995-2012); PO IJ sselmeer (in brackets; 2001-current).

\begin{tabular}{lrrrrrrrrrrrrrrr}
\hline DECADE & $\mathbf{1 9 0 0}$ & $\mathbf{1 9 1 0}$ & $\mathbf{1 9 2 0}$ & $\mathbf{1 9 3 0}$ & $\mathbf{1 9 4 0}$ & $\mathbf{1 9 5 0}$ & $\mathbf{1 9 6 0}$ & $\mathbf{1 9 7 0}$ & $\mathbf{1 9 8 0}$ & $\mathbf{1 9 9 0}$ & $\mathbf{2 0 0 0}$ & $\mathbf{2 0 1 0}$ & \\
YEAR & & & & & & & & & & & \\
\hline 0 & 324 & 620 & 1157 & 838 & 3205 & 4152 & 2999 & 1112 & 641 & 472 & 368 \\
1 & 387 & 988 & 989 & 941 & 4563 & 3661 & 2460 & 853 & 701 & 573 & $381(405)$ & $62(124)$ \\
2 & 514 & 720 & 900 & 1048 & 3464 & 3979 & 1443 & 857 & 820 & 548 & $353(343)$ & $59(121)$ \\
3 & 564 & 679 & 742 & 2125 & 1021 & 3107 & 1618 & 823 & 914 & 293 & $279(293)$ \\
4 & 586 & 921 & 846 & 2688 & 1845 & 2085 & 2068 & 841 & 681 & 330 & $245(280)$ \\
5 & 415 & 1285 & 965 & 1907 & 2668 & 1651 & 2309 & 1000 & 666 & 354 & $234(238)$ \\
6 & 406 & 973 & 879 & 2405 & 3492 & 1817 & 2339 & 1172 & 729 & 301 & $230(224)$ \\
7 & 526 & 1280 & 763 & 3595 & 4502 & 2510 & 2484 & 783 & 512 & 285 & $130(188)$ \\
8 & 453 & 1111 & 877 & 2588 & 4750 & 2677 & 2222 & 719 & 437 & 323 & $122(141)$ \\
9 & 516 & 1026 & 1033 & 2108 & 3873 & 3412 & 2241 & 510 & 525 & 332 & $58(105)$ \\
\hline
\end{tabular}

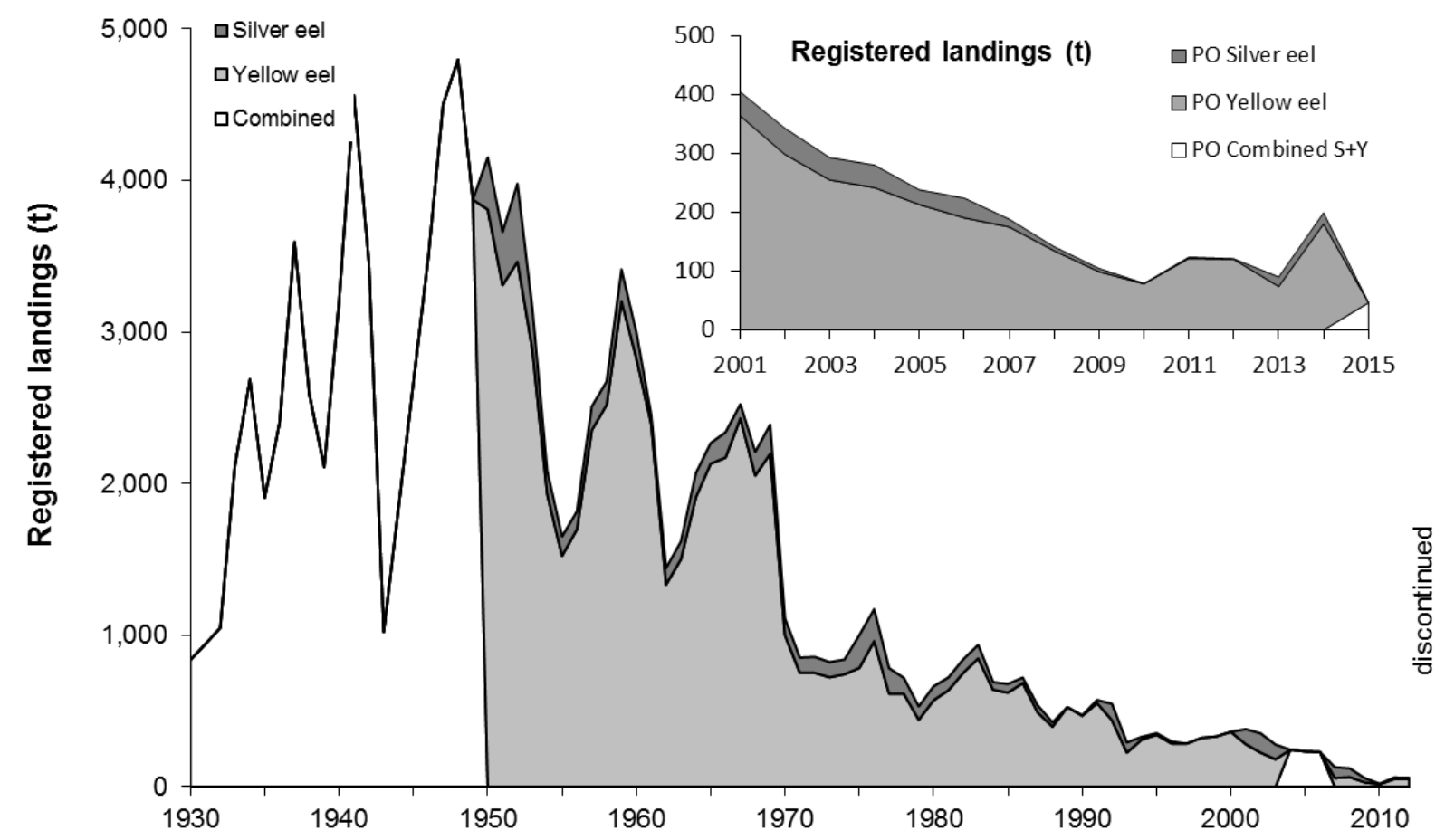

Figure NL. 4. Main graph: Time series of landings of yellow eel and silver eel from Lake IJ sselmeer/Markermeer at auctions. Source data main graph EZ and Productschap Vis. Inserted graph: catches of yellow eel and silver eel recorded by PO Ijsselmeer.

\subsection{Recreational} NO AVAILABLE DATA. 


\subsubsection{Silver eel}

\subsection{Commercial}

No reliable long term time series of yellow eel landing exist. Data on total landings of yellow and silver eel combined have been reported for Lake IJ sselmeer/Markermeer. Data from auctions around Lake I) sselmeer did report yellow and silver eel separately, but information in recent years (early 1990s onwards) is unreliable: yellow eel from eel boxes and silver eel from all gears have been combined and labelled 'silver eel' (see section 6.2. for details). In addition, catches registered by the PO IJ sselmeer from 2001 onwards do distinguish silver eel from other eel catches. However, some silver eel may still be reported amongst the catches of 'other eel'. Still, landings and catches of silver eel are included "as is" in the figure of yellow eel landings and catches (Figure NL. 4). An obligatory catch registration system has been introduced in the Netherlands in January 2010 by the Ministry of Economic Affairs (EZ). However, weekly catches of eel have been reported, but they consist of combined data for yellow eel and silver eel and no information on effort or gears have been reported.

\subsection{Recreational NO AVAILABLE DATA.}




\subsubsection{Marine fishery}

Only the number of vessels reporting eel catches are known. These are reported in paragraph 3.1.5.4, Figure NL. 8.

\subsubsection{Spatial subdivision of the territory}

The fishing areas in the Netherlands can be categorised into five groups:

1. The Wadden Sea; 53N 5E; $2,591 \mathrm{~km}^{2}$. This is an estuarine-like area, shielded from the North Sea by a series of islands. The inflow of sea water at the western side mainly consists of the outflow of the river Rhine, which explains the estuarine character of the Wadden Sea. The fishery in the Wadden Sea is permitted to license holders and assigns specific fishing sites to individual licensees. Fishing gears include fyke nets and pound nets; the traditional use of eel pots is in rapid decline. The fishery in the Wadden Sea is obliged to apply standard EU fishing logbooks. Landings statistics are therefore available from 1995 onwards; $<50$ tons per year. In 2009 there were 21 companies having a commercial license for fishing eel, and the total number of fyke nets was estimated at 400 .

2. Lake IJsselmeer; $52040^{\prime} \mathrm{N} 5025^{\prime} \mathrm{E}$; now $1820 \mathrm{~km}^{2}$. Lake IJsselmeer is a shallow, eutrophic freshwater lake, which was reclaimed from the Wadden Sea in 1932 by a dike (Afsluitdijk), substituting the estuarine area known before as the Zuiderzee. The surface of the lake was reduced stepwise by land reclamation, from an original $3,470 \mathrm{~km}^{2}$ in 1932 , to $1,820 \mathrm{~km}^{2}$ since 1967. In preparation for further land reclamation, a dam was built in 1976, dividing the lake into two compartments of 1,200 and $620 \mathrm{~km}^{2}$, respectively, but no further reclamation has actually taken place. In managing the fisheries, the two lake compartments have been treated as a single management unit. The discharge of the river IJ ssel into the larger compartment (at 52035' $5^{\circ}=50^{\prime} \mathrm{E}$, average $7 \mathrm{~km}^{3}$ per annum, coming from the River Rhine) is sluiced through the Afsluitdijk into the Wadden Sea at low tide, by passive fall. Fishing gears include standard and summer fyke nets, eel boxes and long lines; trawling was banned in 1970. Licensed fishermen are not spatially restricted within the lake, but the number of gears is controlled by a gear-tagging system. The registered landings at the auctions are assumed to cover some the actual total. There are, however, differences in estimated landings reported by the fisheries organisation (PO IJsselmeer), the Fish Board (PVIS) and catch registration system of the Ministry of Economic Affairs (Ministerie van EZ). In 2009 there were 70 fishing licenses, owned by about 30 companies. The total number of gears allowed in 2015 was: fixed fykes 1733, train fykes 6328, eel boxes 7415 and unknown numbers of longlines.

3. Main rivers; $180 \mathrm{~km}^{2}$ of water surface. The Rivers Rhine and Meuse flow from Germany and Belgium respectively, and in the Netherlands constitute a network of dividing and joining river branches. Traditional eel fisheries in the rivers have declined tremendously during the $20^{\text {th }}$ century, but following water rehabilitation measures in the last decades, is now slowly increasing. The traditional fishery used stow nets for silver eel, but fyke net fisheries for yellow and silver eel now dominates. Individual fishermen are licensed for specific river stretches, where they execute the sole fishing right. No registration of effort is required. In 2009 there were 28 fishing companies, using an estimated number of 318 fixed fykes, 2433 train fykes, 551 eel boxes, and unknown quantities of other gears (electric dipnet, longlines, etc). Since 1 April 2011 the eel fishery on the main rivers has been closed due to high levels of pollutants in eel.

4. Zeeland; $965 \mathrm{~km}^{2}$. In the Southwest, the Rivers Rhine, Meuse and Scheldt (Belgium) discharge into the North Sea in a complicated network of river branches, lagoon-like waters and estuaries. Following a major storm catastrophe in 1953, most of these waters have been (partially) closed off from the North Sea, sometimes turning them into fresh water bodies. Fishing is licensed to individual fishermen, mostly spatially restricted. Fishing gears are dominated by fyke nets. Management is partially based on marine, partly on fresh water legislation. In 2009 there are 27 companies, using an estimated number of 174 fixed fykes, 233 train fykes, and unknown numbers of eel pots. This area has also been affected by the ban on eel and Chinese mitten crab fishery due to high pollution levels. 
5. Remaining waters; inland $1,340 \mathrm{~km}^{2}$. This comprises $636 \mathrm{~km}^{2}$ of lakes (average surface: 12.5 $\mathrm{km}^{2}$ ); $386 \mathrm{~km}^{2}$ of canals (> $6 \mathrm{~m}$ wide, $27,590 \mathrm{~km}$ total length); $289 \mathrm{~km}^{2}$ of ditches $(<6 \mathrm{~m}$ wide, $144,605 \mathrm{~km}$ total length); and $28 \mathrm{~km}^{2}$ of smaller rivers (all estimates based on areas less than $1 \mathrm{~m}$ above sea level, 55\% of the total surface; see Tien and Dekker 2004 for details). Traditional fisheries are based on fyke netting and hook and line. Individual licenses permit fisheries in spatially restricted areas, usually comprising a few lakes or canal sections, and the joining ditches. Only the spatial limitation is registered. Eight small companies operating scattered along the North Sea coast have been added to this category. In 2009 there were about 100 companies, using unknown quantities of gears of all types.

The Water Framework Directive subdivides the Netherlands into four separate River Basin District (RBD), all of which extend beyond our borders. These are:

1. the River Ems (Eems), 5320'N 7일 (=river mouth), shared with Germany. This RBD includes the north-eastern Province Groningen, and the eastern part of Province Drenthe. Drainage area: $18,000 \mathrm{~km}^{2}$, of which $\underline{2,400 \mathrm{~km}^{2}}$ in the Netherlands.

2. the River Rhine (Rijn), 5200'N 410'E, shared with Germany, Luxemburg, France, Switzerland, Austria, Liechtenstein. Drainage area: $185,000 \mathrm{~km}^{2}$, of which $25,000 \mathrm{~km}^{\underline{2}}$ in the Netherlands, which is the major part of the country.

3. the River Meuse (Maas), 515' $\mathrm{N}$ 400' $\mathrm{E}$, shared with Belgium, Luxemburg, France and Germany. Drainage area: $35,000 \mathrm{~km}^{2}$, of which $\underline{8,000 \mathrm{~km}^{2}}$ in the Netherlands.

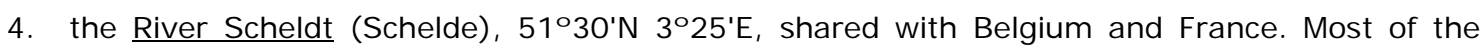
south-western Province Zeeland used to belong to this RBD, but water reclamation has changed the situation dramatically. Drainage area: $22,000 \mathrm{~km}^{2}$, of which $1,860 \mathrm{~km}^{\underline{2}}$ in the Netherlands.

Within the Netherlands, all rivers tend to intertwine and confluent. Rivers Rhine and Meuse have a complete anastomosis at several places, whereas a large part of the outflow of the River Meuse is now redirected through former outlets of the River Scheldt. Additionally, the coastal areas in front of the different RBDs constitute a confluent zone. Consequently, sharp boundaries between the RBDs cannot be made - neither on a practical nor on a juridical basis. This report will subdivide the national data on a pragmatic basis.

In this report, we will subdivide the national data on eel stock and fisheries by drainage area on a preliminary assumption that water surfaces and fishing companies are approximately equally distributed over the total surface, and thus, totals can be split up over RBDs proportionally to surface areas.

\subsubsection{Fishing capacity}

Capacity is defined as the potential fishery usage (i.e. number of licences issued). For marine waters and Lake IJ sselmeer a register of ships is kept, but for the other waters no central registration of the ships being used is available. Registration of the number of gears owned or employed was lacking until recently.

For Lake IJ sselmeer/Markermeer (Figure NL. 5), an estimate of the number of gears actually used is available for the years 1970-1988 (Dekker 1991). In the mid-1980s, the number of fyke nets was capped, and reduced by $40 \%$ in 1989. In 1992 the number of eel boxes was counted, and capped. Subsequently, the caps have been lowered further in several steps, the latest being a buy-out in 2006. Since the number of companies has reduced at the same time, the nominal fishing effort per company has not reduced at the same rate, and underutilisation of the nominal effort probably still exists. The effort in the longline fishery is not restricted, other than by the number of licenses. 


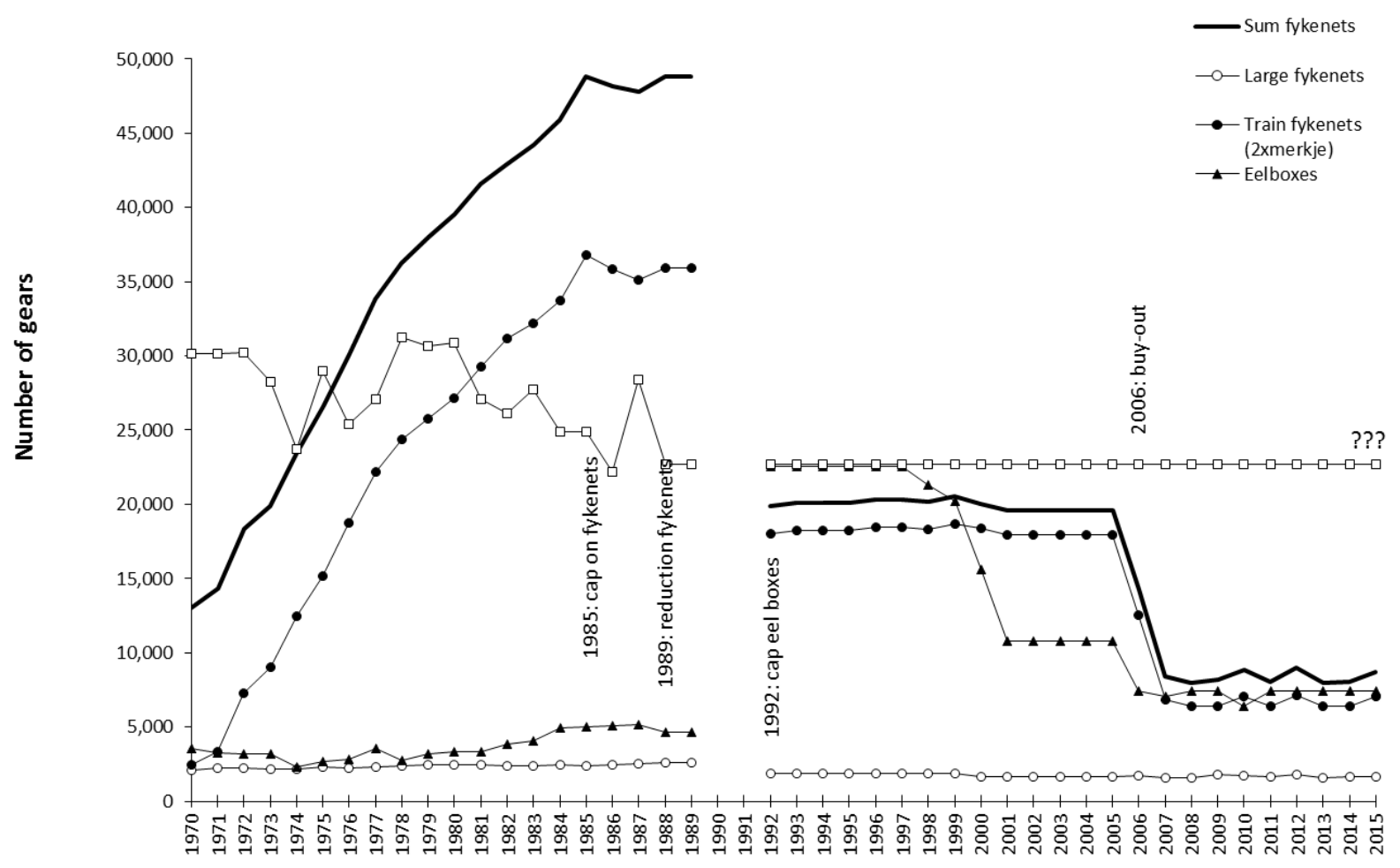

Figure NL. 5. Trends in the nominal number of fishing gear employed in the eel fishery on Lake IJ sselmeer/Markermeer. Information before 1989 is based on a voluntary inquiry in 1989 (Dekker 1991); after 1992, the licensed number of gear is shown. Note that long line fishery is only restricted by the number of licences, the number of long lines per licence is not regulated. The number of long lines since 1992 is unknown.

\subsubsection{Fishing effort}

Effort is defined as the actual fishery usage (i.e. number of licences fished, number of net nights etc).

\subsubsection{Glass eel}

No fishing on glass eel.

\subsubsection{Yellow eel and silver eel}

No distinction between fishing effort on yellow eel and silver eel could be made and as a result data are combined.

For most of the country, fishing effort was unknown until 2012. In areas where fishing capacity was known (IJsselmeer/Markermeer), no record had been kept of the actual usage of fishing gears. For Lake IJ sselmeer, a maximum number of gears by company is enforced (authenticated tags are attached to individual gears), but the actual usage is often much lower, amongst others since restrictions apply on the combinations of types of fishing gears (e.g. fyke nets and gill nets should not be operated concurrently, since perch and pikeperch are target species of the gill netting, whereas landing perch and pikeperch from fyke nets is prohibited).

A national catch registration system was introduced by Ministry of Economic Affairs on 1/1/2010. Since 2012, eel fishers are obliged for the first time to record their effort weekly in addition to their catches; all eel fishers have to record the type of gear and number of gear used. Overviews of the number and type of gear deployed weekly throughout 2015 is presented in Figure NL. 7A for Lake IJ sselmeer/Markermeer (combined) and in Figure NL. 7B for the other locations in The Netherlands (combined). In general, effort was fairly constant throughout the season, with at most a slight increase during the season. Only eelboxes were deployed mainly in the first half of the season. In Figure NL. 8 the developments between years is shown for CPUE, effort and catch. 

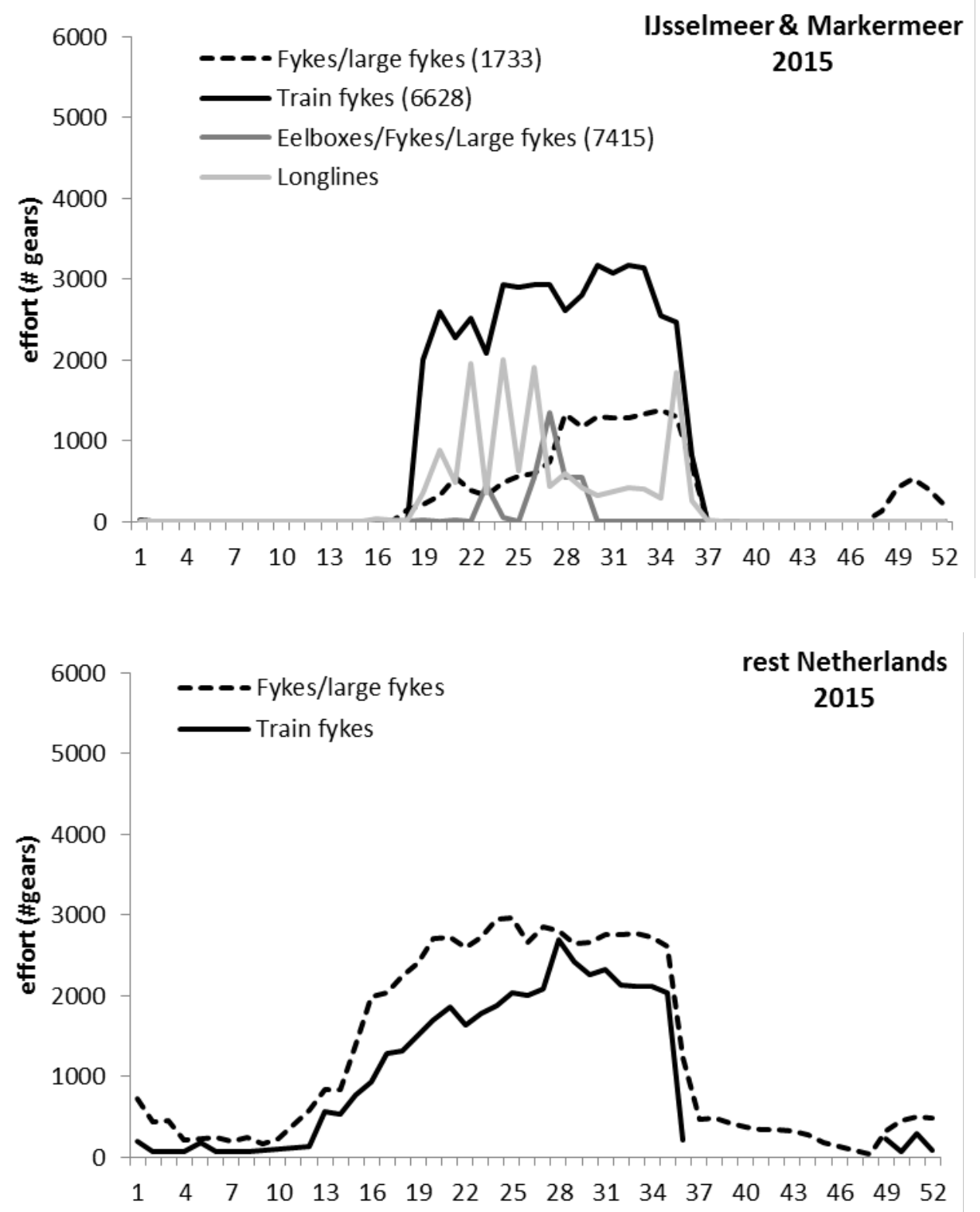

Figure NL. 6. (A) The number of fishing gear employed weekly in 2015 in the eel fishery on Lake IJ sselmeer and Markermeer (Source Ministry of Economic Affairs) and (B) on other locations throughout the Netherlands (source Ministry of Economic Affairs). 

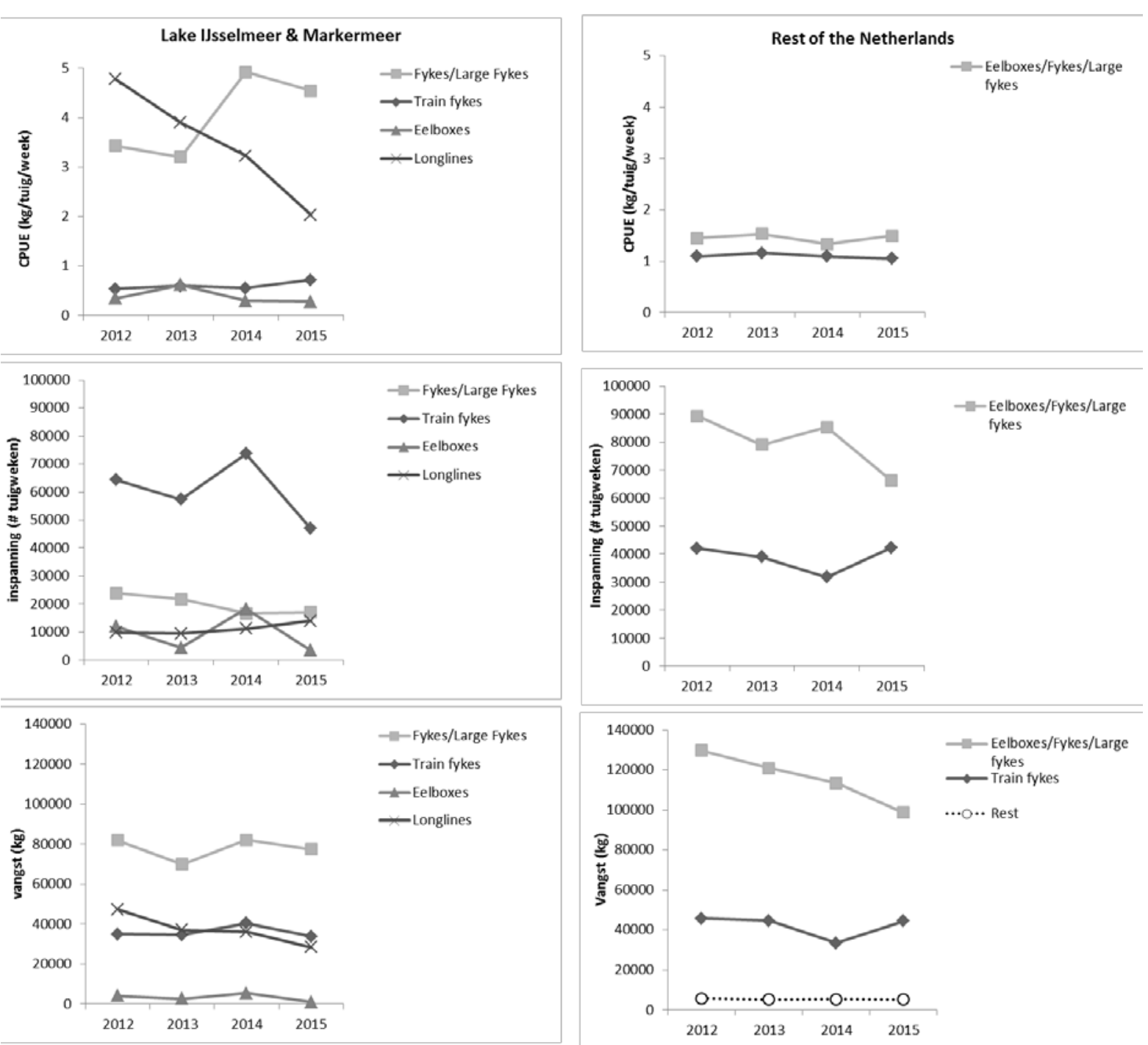

Figure NL. 7. Time series of fishing gear in the Dutch eel fishery in Lake IJ sselmeer and Lake Markermeer versus the rest of the Netherlands (source Ministry of Economic Affairs).

\subsubsection{Silver eel}

No distinction between fishing effort on yellow eel and silver eel. Data are combined and reported under yellow eel (Paragraph 3.1.1.2).

\subsubsection{Marine fishery}

Only the number of vessels reporting eel catches are known. These are reported in paragraph 3.1.5.4, Figure NL. 8.

\subsubsection{Catches and landings}

\subsubsection{Glass eel}

Glass eel fishing is forbidden; no data available.

\subsubsection{Yellow eel}

\subsection{Catches and/or landings from Lake IJ sselmeer/Markermeer}

The fishers organisation (PO IJ sselmeer) has kept records of the catches of their associated fishers (>90\% of the fishers active in the IJ sselmeer area) from 2001 onwards (see section NL 3.1.1.2.1). Yellow eel catches and silver eel catches are reported separately (Table NL. I). In addition, in January 2010 an obligatory catch registration system was introduced in the Netherlands by the Ministry of 
Economic Affairs. In this program weekly catches of eel are reported, but yellow eel and silver eel catches are combined (Table NL. J, Figure NL. 9). No information on effort and gears is reported. Catches from Lake IJ sselmeer have declined following the partial ban on eel fishery (SeptemberNovember annually) as a result of the Council regulation for European Eel (2008) and the ensuing Dutch Eel management plan.

Table NL. I. Left table: Catches of yellow eel in tonnes by year for the IJ sselmeer area. Right table: Catches of silver eel in tonnes by year for the IJ sselmeer area (data 2001-2015). (Source: PO IJ sselmeer). For 2015, silver and yellow eel are combined.

\begin{tabular}{|c|c|c|c|c|c|}
\hline \multicolumn{3}{|c|}{ YELloW EEL } & \multicolumn{3}{|c|}{ SILVER EEL } \\
\hline Decade & 2000 & 2010 & DECADE & 2000 & 2010 \\
\hline YEAR & & & YEAR & & \\
\hline 0 & & 78 & 0 & & 1 \\
\hline 1 & 364 & 122 & 1 & 41 & 2 \\
\hline 2 & 299 & 120 & 2 & 44 & 1 \\
\hline 3 & 255 & 74 & 3 & 38 & 16 \\
\hline 4 & 242 & 180 & 4 & 38 & 19 \\
\hline 5 & 213 & 46 (s+y eel) & 5 & 25 & 46 (s+y eel) \\
\hline 6 & 191 & & 6 & 33 & \\
\hline 7 & 175 & & 7 & 13 & \\
\hline 8 & 135 & & 8 & 7 & \\
\hline 9 & 99 & & 9 & 5 & \\
\hline
\end{tabular}

4.1.5.2.2 Catches and/or landings from other areas In January 2010, an obligatory catch registration system was introduced in the Netherlands by the Ministry of Economic Affairs (EZ). In this program weekly catches of eel are reported, but yellow eel and silver eel catches are combined (Table NL. J). No information on effort and gears is reported. The reduction in catches following the closure of a most river systems in 2011 due to high contaminant levels in eel is apparent (Table NL. J).

Table NL. J. Comparison of combined yellow eel and silver eel catches (2010-2015) from different sources for IJ sselmeer area and other areas in The Netherlands.

\begin{tabular}{lcccc}
\hline SOURCE & IJSSELMEER & & OTHER AREAS & TOTAL \\
\hline 2010 & PO & EZ & EZ & EZ \\
\hline 2011 & 79 & 128 & 324 & 452 \\
\hline 2012 & 124 & 179 & 188 & 367 \\
\hline 2013 & 121 & 168 & 182 & 350 \\
\hline 2014 & 90 & 144 & 171 & 315 \\
\hline 2015 & 199 & 163 & 153 & 317 \\
\hline
\end{tabular}

\subsubsection{Silver eel}

The fishers organisation (PO IJ sselmeer) has kept records of the catches of their associated fishers ( $>90 \%$ of the fishers active in the IJ sselmeer area) from 2001 onwards (see section NL 3.1.1.2.1). Yellow eel catches and silver eel catches are reported separately, but not for 2015 (Table NL. I). Catches from the IJ sselmeer area have declined following the partial ban on eel fishery (SeptemberNovember annually) as a result of the Council regulation for European Eel (2008) and the ensuing 
Dutch Eel management plan. Catches in 2014 reported by PO IJ sselmeer were high compared to the previous years, while catches of 2015 (yellow + silver eel) were low.

\subsubsection{Marine fishery}

Catches and landings in marine waters are registered in EU logbooks, but these do not allow for a break down by river basin district. Annual registrations are available since 1995; data prior to 1984 are presented in the 2009 Country Report. Until 2001, vessels with a total length (LOA) $\geq 15$ m were obliged to report all their eel catches; this obligation did not apply to smaller vessels. From 2001 onwards, vessels with a total length $\geq 10 \mathrm{~m}$ have been obliged to report their eel catches, but only if their landings per day exceeded $50 \mathrm{~kg}$. Thus, in 2001 the number of ships potentially reporting eel catches rose, but the actual reporting per ship potentially declined. This change the regulation was partly driven by changing practices, and vice versa.

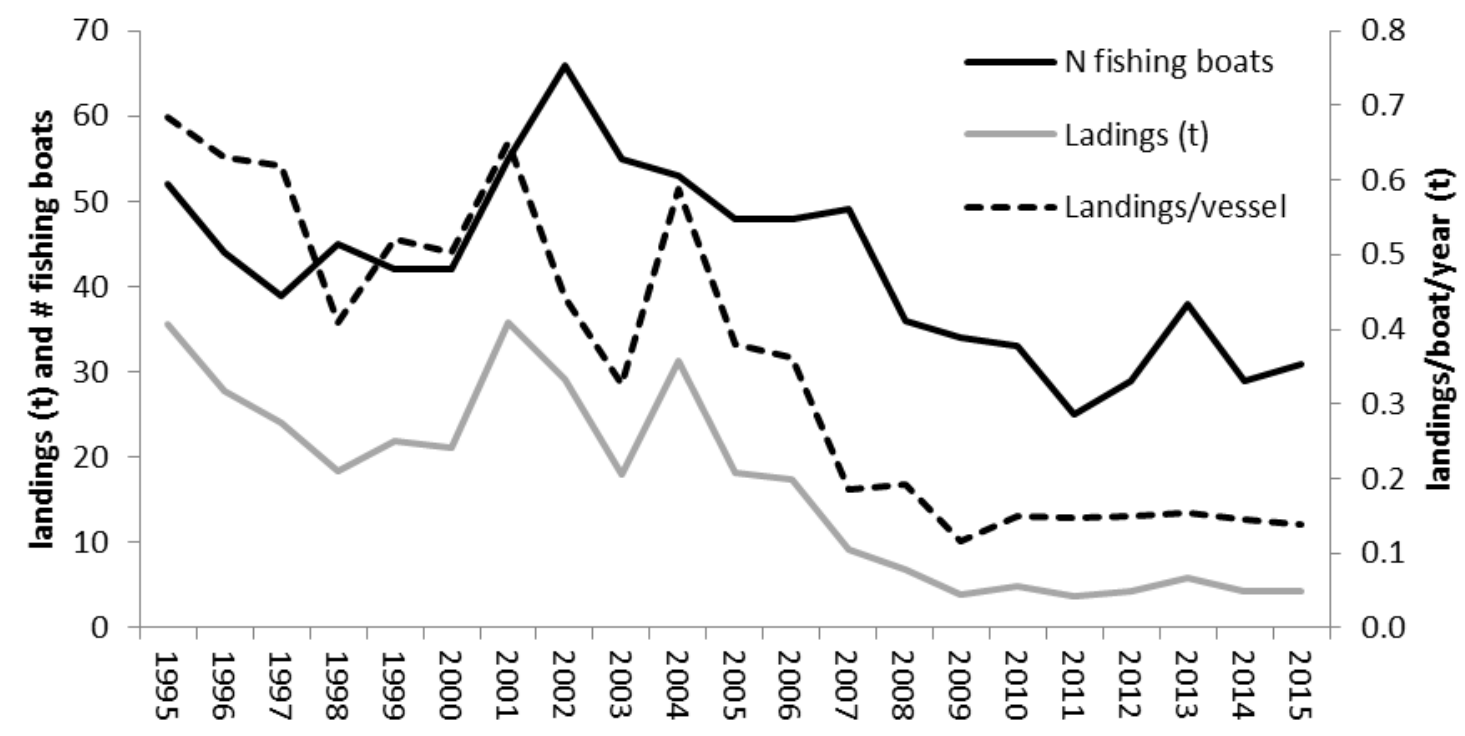

Figure NL. 8. Registered landings of eel (no distinction available between yellow eel and silver eel) from marine waters in Dutch harbours between 1995-2015.

The number of vessels reporting eel catches, total landings and the landings per vessel declined from 2001 until 2009. Since 2009, landings and landings by vessel have remained more or less constant, whereas the number of vessels reporting catches varied between 25 and 38 between 2009 and 2015.

\subsubsection{Recreational Fishery}

In 2009 an extensive Recreation Fisheries Program was started in the Netherland. In December 2009, 50,000 households were approached during the screening survey to determine the number of recreational fishermen in the Netherlands (result 1.69 million recreational fishermen). In 2010, 2000 recreational fishermen were selected for a 12-month logbook programme (March 2010 - February 2011). In the Netherlands about 1,500,000 eels were caught by recreational fishermen, while about 500,000 eels were retained. Due to the lack of reliable length frequency data of the eel caught, raising the number of eel caught to a biomass estimate of eel caught remains difficult (Van der Hammen $\&$ de Graaf, 2012). The program was repeated in 2012/2013 (Van der Hammen \& de Graaf, 2015) with 2400 fisherman from the 2009 survey with an additional 100 fanatic fishermen that were recruited at recreational fishery websites. It was estimated that recreational fishers in marine waters retained 91,000 eels and returned 67,000 eels (in total 18 tons retained), although these numbers are less precise than those of fresh water catches. In fresh waters the anglers were estimated to have retained 313,000 eels and have returned $1,517,000$ eels ( 41 tons retained). The number of recreational fishers was estimated to have declined from 1.7 million in 2009 to 1.4 million in 2011 and 1.3 in 2013. In 2012, the 41 tons of landed eels made $11 \%$ of the total landings, the major part consisting of $372 \mathrm{t}$ of commercial landings (Van der Hammen \& de Graaf, 2015). 
Table NL. K. Recreational Fisheries: retained and released catches of eel (in numbers) in the Netherlands in inland and marine areas. Only estimated numbers from angling were available (Van der Hammen \& de Graaf, 2013, 2015).*data less accurate.

\begin{tabular}{|c|c|c|c|c|c|c|c|c|}
\hline & RETAINED & & & & RELEASED & & & \\
\hline & INLAND & & MARINE & & INLAND & & MARINE & \\
\hline YEAR & ANGLING & $\begin{array}{l}\text { PASSIVE } \\
\text { GEARS }\end{array}$ & ANGLING & $\begin{array}{l}\text { PASSIVE } \\
\text { GEARS }\end{array}$ & ANGLING & $\begin{array}{l}\text { PASSIVE } \\
\text { GEARS }\end{array}$ & ANGLING & $\begin{array}{l}\text { PASSIVE } \\
\text { GEARS }\end{array}$ \\
\hline 2010 & 341,000 & $\begin{array}{c}\text { Not } \\
\text { allowed }\end{array}$ & 180,000 & $\begin{array}{c}\text { Not } \\
\text { known }\end{array}$ & 887,000 & $\begin{array}{c}\text { Not } \\
\text { allowed }\end{array}$ & 117,000 & $\begin{array}{c}\text { Not } \\
\text { known }\end{array}$ \\
\hline 2012 & 313,000 & $\begin{array}{c}\text { Not } \\
\text { allowed }\end{array}$ & $91,000^{*}$ & $\begin{array}{c}\text { Not } \\
\text { known }\end{array}$ & $1,517,000$ & $\begin{array}{c}\text { Not } \\
\text { allowed }\end{array}$ & $67,000^{*}$ & $\begin{array}{c}\text { Not } \\
\text { known }\end{array}$ \\
\hline
\end{tabular}

Table NL. L. Recreational Fisheries: catch and release mortality for eel in the Netherlands (Van der Hammen \& de Graaf, 2015 based on Bartholomew \& Bohnsack, 2005).

\begin{tabular}{ccccc}
\hline \multicolumn{3}{c}{ RELEASED } & & \\
\hline & INLAND & & MARINE & \\
\hline YEAR & ANGLING & $\begin{array}{l}\text { PASSIVE } \\
\text { GEARS }\end{array}$ & ANGLING & $\begin{array}{l}\text { PASSIVE } \\
\text { GEARS }\end{array}$ \\
\hline 2012 & $12 \%$ & $\begin{array}{c}\text { Not } \\
\text { allowed }\end{array}$ & $12 \%$ & $\begin{array}{c}\text { Not } \\
\text { known }\end{array}$ \\
\hline
\end{tabular}




\subsubsection{CPUE}

NO AVAILABLE DATA

\subsubsection{Illegal, unreported and unregulated (IUU) fishing}

The task of adherence to rules and regulations pertaining to eel fishery is carried out by the Netherlands Food and Consumer Product Safety Authority (NVWA). Following indication of illegal eel fishing in 2012, they intensified their monitoring in 2013. In 2015 in total 202 fishing gears associated with illegal eel fishing were seized.

Table NL. M. Overview of suspected causes of illegal fishing activities in the Netherlands (2013).

\begin{tabular}{llcc}
\hline \multicolumn{2}{l}{ Cause } & IJsselmeer & other areas \\
\hline 1. & Fishing out of the season & ND & ND \\
2. & Fishing without licence & ND & ND \\
3. & Fishing using illegal gears & ND & ND \\
4. & Retention of eel below size limit & ND & ND \\
5. & Illegal selling of catches & ND & ND \\
6 & Fishing in closed areas & ND & $\mathrm{Y}$ \\
\hline
\end{tabular}

\subsection{Aquaculture production and restocking}

\subsubsection{Seed supply}

Table NL. N. Origin of glass eel used for aquaculture in the Netherlands since 2010 (Source DUPAN).

\begin{tabular}{lrrrr}
\hline SEASON & FrancE & SPAIN & ENGLAND & TOtAL (KG) \\
\hline $2010 / 2011$ & 4725 & 1890 & 135 & 6750 \\
\hline $2011 / 2012$ & 5325 & 1350 & 100 & 6775 \\
\hline $2012 / 2013$ & 5500 & 650 & 550 & 6700 \\
\hline $2013 / 2014$ & 3400 & 250 & 1250 & 4900 \\
\hline $2014 / 2015$ & 4400 & 500 & 300 & 5200 \\
\hline $2015 / 2016$ & 5200 & & Few hundred & 5500 \\
\hline
\end{tabular}

*assuming 'a few hundred' to be $300 \mathrm{~kg}$ 


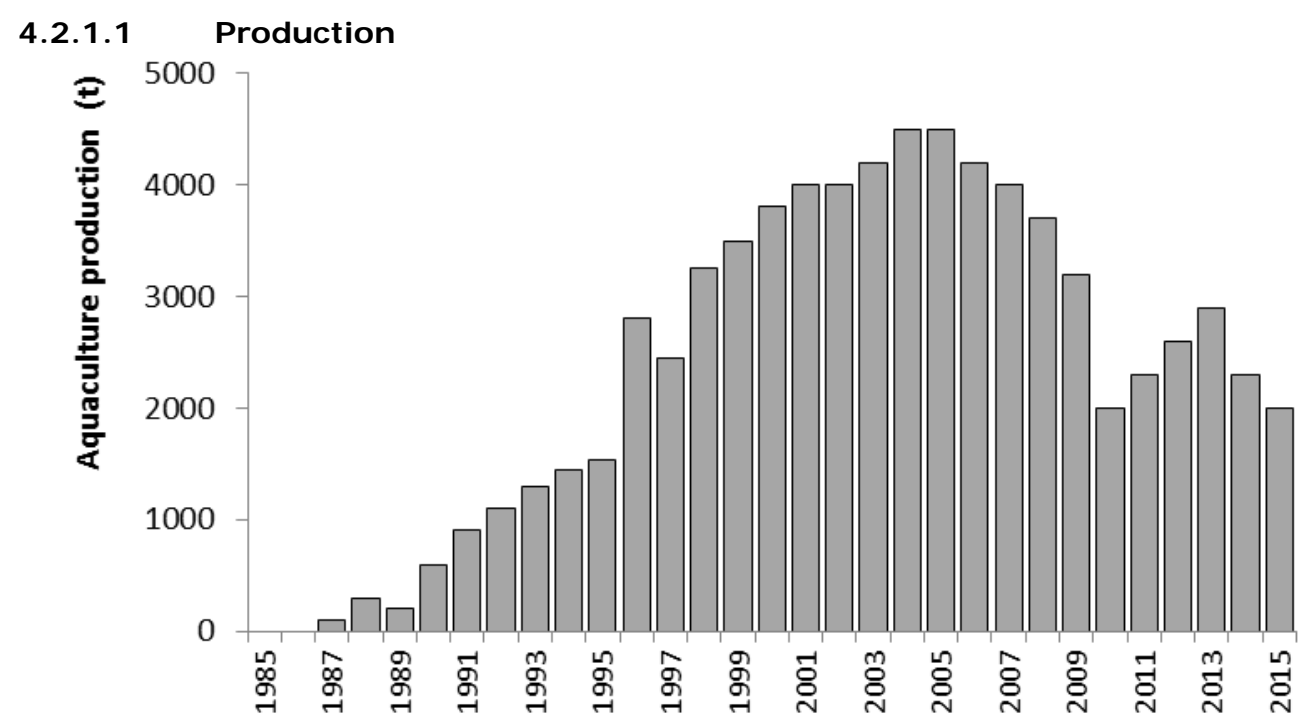

Figure NL. 9. Trend in aquaculture production of yellow eel for consumption in the Netherlands. In 2015, the production was 22000 t (Source DUPAN).

\subsubsection{Amount stocked}

Table NL. O Overview of glass eel and young yellow eel stocked in the Netherlands in 2016 (Source DUPAN and (VB). The location where they have been raised is set between brackets in the column 'Origin'.

\begin{tabular}{lllrrr}
\hline DATE & STOCKING LOCATION & ORIGIN & KG & N & N/KG \\
\hline GLASSEEL & & & & & \\
\hline $17-03-2016$ & Friese Boezem & France & 636 & $2,247,000$ & 3533 \\
\hline $29 / 04 / 2016$ & Friese Boezem & France & 134 & 462,000 & 3448 \\
\hline $15 / 04 / 2016$ & Veerse Meer & France & 79 & 252,000 & 3190 \\
\hline $15 / 04 / 2016$ & Otheense Kreek en Braakman & France & 26 & 81,000 & 3115 \\
\hline$?$ & Zeeland & $?$ & 15 & 52,632 & 3509 (1) \\
\hline$?$ & Zuid-Holland & $?$ & 60 & 210,526 & 3509 (1) \\
\hline TOTAL & & & 950 & $3,305,158$ &
\end{tabular}

\begin{tabular}{llrrrr}
\hline YOUNG YELLOW EEL & & & & & \\
\hline $17 / 06 / 2016$ & Grevelingen & France & 1,432 & 490,000 & 342 \\
\hline $11 / 06 / 2016$ & Kampen $^{(2)}$ & France & 96 & 27,000 & 281 \\
\hline TOTAL & & 1,528 & 517,000 & \\
\hline TOTAL glasseel+yellow eel & & 2,478 & $3,822,158$ \\
\hline
\end{tabular}

(1) Assuming $0.285 \mathrm{~g} /$ eel (DUPAN)

(2) source: http://www.rtvoost.nl/tag/paling?nid=246329 


\subsubsection{Reconstructed Time Series on Stocking}

No (historical) data available with regards to origin and whether or not stocked eels were quarantined, overall all stocked of glass eel (see Fig. NL.7) is sourced outside the Netherlands.

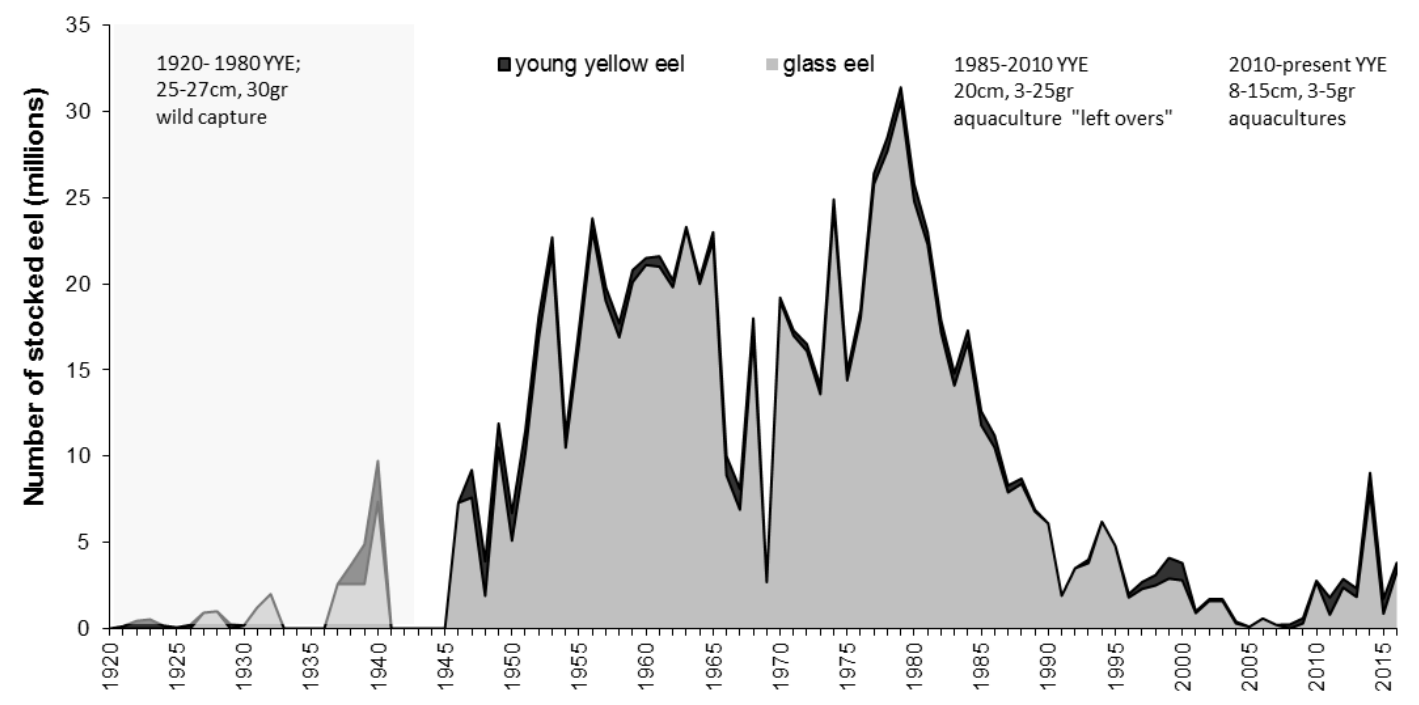

Figure NL. 10. Overview of stocking of glass eel and young yellow eel in the Netherlands (19202016). Note that the average weight of stocked young yellow eel decreased from $\sim 30 \mathrm{~g}$ to $\sim 3 \mathrm{~g}$ between 1920 and 2010. 


\subsubsection{Aquaculture Seed supply}

Table NL. P. Origin of glass eel used for aquaculture in the Netherlands since 2010 (Source DUPAN).

\begin{tabular}{lrrrr}
\hline SEAson & France & Spain & England & Total (KG) \\
\hline $2010 / 2011$ & 4725 & 1890 & 135 & 6750 \\
\hline $2011 / 2012$ & 5325 & 1350 & 100 & 6775 \\
\hline $2012 / 2013$ & 5500 & 650 & 550 & 6700 \\
\hline $2013 / 2014$ & 3400 & 250 & 1250 & 4900 \\
\hline $2014 / 2015$ & 4400 & 500 & 300 & 5200 \\
\hline $2015 / 2016$ & 5200 & 0 & Few hundred & 5500 \\
\hline
\end{tabular}

\subsubsection{Glass eel use}

About $5500 \mathrm{~kg}$ of glass eel was imported from France in winter (Table NL. P) and used for aquaculture. Part of these glass eel were used for stocking later in the year (1528 kg) (Table NL. Q). In addition, another $950 \mathrm{~kg}$ was imported in April and used for stocking directly (Table NL. Q). A schematic overview is given in Figure NL. 10.

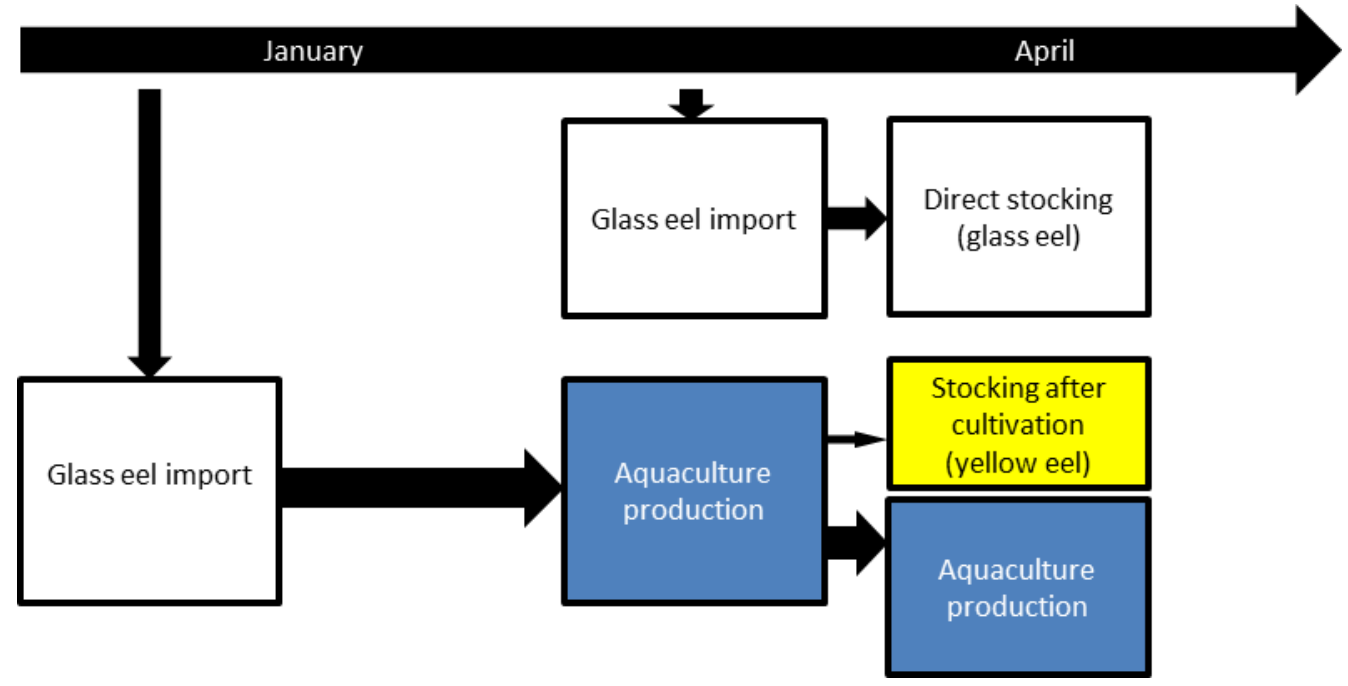

Figure NL. 11. Schematic overview of the fate of imported glass eel. Glass eel imported in winter for aquaculture production is partly used for restocking as yellow eel. Glass eel imported in spring is directly used for stocking.

\subsection{Entrainment}

Details on entrainment can be found in Van de Wolfshaar et al. (2015)

\subsection{Habitat Quantity and Quality}

General information on habitat quantity is mentioned in paragraph 3.1.2 and in Van de Wolfshaar et al. (2015).

Table NL. Q. Overview of the assessed impacts per habitat type or for 'All' habitats where the assessment is applied across all relevant habitats. Barriers include habitat loss; indirect impacts are anthropogenic impacts on the ecosystem, but only indirectly on eel (e.g. eutrophication). $A=$ assessed, $\mathrm{MI}=$ not assessed, minor, $\mathrm{MA}=$ not assessed major, $\mathrm{AB}=$ impact absent $($. 


\begin{tabular}{|c|c|c|c|c|c|c|c|c|}
\hline EMU CODE & НАBITAT & $\begin{array}{l}\text { FISH } \\
\text { COM }\end{array}$ & $\begin{array}{l}\text { FISH } \\
\text { REC }\end{array}$ & $\begin{array}{l}\text { HYDRO \& } \\
\text { PUMPS }\end{array}$ & BARRIERS & RESTOCKING & Predators & $\begin{array}{l}\text { INDIRECT } \\
\text { IMPACTS }\end{array}$ \\
\hline \multirow[t]{6}{*}{ NL_Neth } & Riv & A & A & A & A & MI/MA & MI/MA & MI/MA \\
\hline & Lak & A & A & A & A & MI/MA & MI/MA & MI/MA \\
\hline & Est & NP & NP & NP & NP & NP & NP & $\mathrm{NP}$ \\
\hline & Lag & NP & NP & $\mathrm{NP}$ & NP & $\mathrm{NP}$ & $\mathrm{NP}$ & $\mathrm{NP}$ \\
\hline & Coa & MI & A & $\mathrm{AB}$ & $\mathrm{AB}$ & $\mathrm{AB}$ & $\mathrm{AB}$ & MI \\
\hline & All & & & & & & & \\
\hline
\end{tabular}

\section{$4.5 \quad$ Others}

\subsubsection{Assisted migration of silver eel}

Since 2011 several (pilot)projects have started at migration barriers (pumping stations) to assist the migration of silver eel. In 20110.54 t of silver eel was caught and released again past barriers at four sites ('assisted migration'). In 2015, almost 6 t was caught and released (Figure NL. 13). However, the mortality rates of silver eel passing the selected barriers has been assessed at moderate to low (Bierman et al. 2012; Winter et al. 2013). Thus, the net amount of eels saved by the assisted migration is much lower than the amount caught and released. In 2013 the barriers for silver eel were prioritised (Winter et al. 2013) to improve the selection and efficiency of assisted migration initiatives. Applying location-specific mortality rates, the net amount of 'saved' eels was $1.1 \mathrm{t}$ (Figure NL. 13).

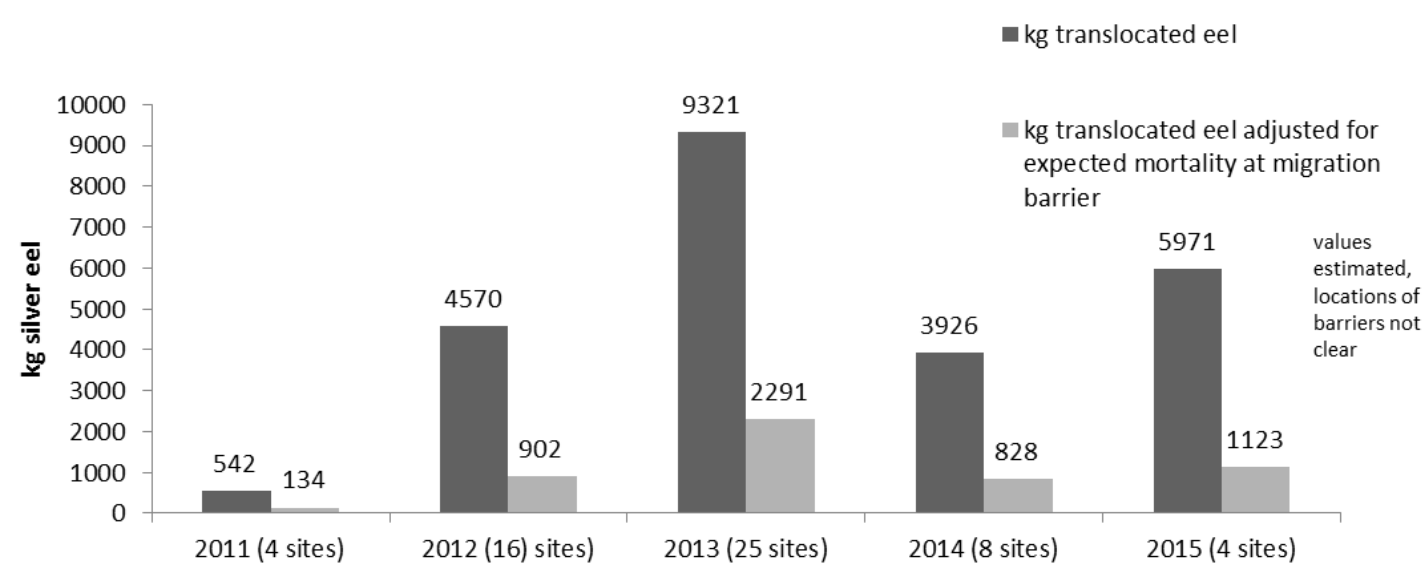

Figure NL. 12. Overview of the "gross" and "net" amount of silver eel assisted over migration barriers in the Netherlands (2011-2015). 


\section{$5 \quad$ National stock assessment}

\subsection{Description of Method}

Methods are described in Van de Wolfshaar et al. (2015) and in Van der Sluis et al. (2015). The status of the Dutch eel population in the framework of the Dutch Eel Management Plan is assessed every 3 years. The latest report is Van de Wolfshaar et al. (2015).

\subsubsection{Data collection}

\begin{tabular}{|c|c|c|c|c|}
\hline GEAR & LOCATION & FREQUENCY & TIME & PERIOD \\
\hline $\begin{array}{l}\text { liftnet } \\
(1 \times 1 \mathrm{~m} ; \text { mesh 1x1mm) }\end{array}$ & Den Oever & daily & $\begin{array}{l}5 \text { hauls every } 2 \\
\text { hours between } \\
\text { 22:00-5:00 }\end{array}$ & Mar-May \\
\hline $\begin{array}{l}\text { liftnet } \\
(1 \times 1 \mathrm{~m} ; \text { mesh } 1 \times 1 \mathrm{~mm})\end{array}$ & $\begin{array}{l}10 \text { other locations } \\
\text { along the coast }\end{array}$ & weekly & $\begin{array}{l}2 \text { hauls at night } \\
\text { time }\end{array}$ & $\sim$ Mar-May \\
\hline \multicolumn{5}{|l|}{ SILVER EEL MONITORING } \\
\hline GEAR & LOCATION & FREQUENCY & TIME & PERIOD \\
\hline Fykes (6 sites) & $\begin{array}{l}\text { Den Oever, } \\
\text { Kornwerderzand, } \\
\text { Noordzeekanaal, } \\
\text { Nieuwe waterweg, } \\
\text { Haringvliet, upper } \\
\text { reaches river Meuse }\end{array}$ & continuous & weekly & Sep-Nov \\
\hline Eel shocker & $\begin{array}{l}\text { upper reaches river } \\
\text { Rhine }\end{array}$ & continuous & once a week & Sep-Nov \\
\hline
\end{tabular}

\begin{tabular}{|c|c|c|c|}
\hline GEAR & LOCATION & FREQUENCY & PERIOD \\
\hline $\begin{array}{l}\text { Fykes }(4) \\
\text { (stretched mesh 18-20mm) }\end{array}$ & Veerse Meer, Haringvliet (North Sea) & continuous & $\sim$ May-Sep \\
\hline $\begin{array}{l}\text { Fykes }(10) \text { or summer fykes } \\
(20-40) \\
\text { (stretched mesh } 18-20 \mathrm{~mm})\end{array}$ & 7 locations in main rivers, estuaries and lakes & continuous & Sep-Nov \\
\hline $\begin{array}{l}\text { Fykes }(10) \text { or summer fykes } \\
(20-40) \\
\text { (stretched mesh } 18-20 \mathrm{~mm})\end{array}$ & 6 locations in main rivers, estuaries and lakes & continuous & Mar-May \\
\hline
\end{tabular}

Due to closure of the eel fishery in polluted areas, this program, which started in the 1990s, has been interrupted. Almost two thirds of the sampling locations were located in the polluted areas and sampling ceased on 1 April 2011. An alternative program to study diadromous fish started in 2012.

ACTIVE MONITORING PROGRAM: MAIN RIVERS

\begin{tabular}{llll}
\hline GEAR & LOCATION & FREQUENCY & PERIOD \\
\hline $\begin{array}{l}\text { Bottom trawl } \\
\text { (channel; 3m beam; }\end{array}$ & $\sim 50$ locations in main rivers & $\begin{array}{l}10 \text { min trawl, 1000m } \\
\text { transect }\end{array}$ & $\sim$ May-Sep \\
15mm stretched mesh) & & & \\
\hline $\begin{array}{l}\text { Electrofishing (shore } \\
\text { area) }\end{array}$ & $\sim 50$ locations in main rivers & 20 min, 600m transect & $\sim$ May-Sep \\
\hline
\end{tabular}


5.1.1.1 Sampling commercial catches

\begin{tabular}{llll}
\hline AREA & SAMPLING FREQUENCY & No. OF FISHERS SAMPLED & GEAR \\
\hline Grevelingen & once & 1 & large fyke \\
Friesland & once & 2 & large fyke \\
Hollands Noorderkwartier & twice & 2 & large fyke \\
IJssel Plus & twice & 1 & large fyke \\
Lauwersmeer & once & 1 & large fyke \\
Noorderzijlvest & once & 1 & large fyke \\
Veluwe Randmeren & twice & 1 & large fyke \\
Rijnland & twice & 1 & large fyke \\
Volkerak-Zoommeer & twice & 1 & large fyke \\
Lake IJsselmeer & once & 1 & train fyke \\
Lake IJsselmeer & once/twice & 2 & large fyke \\
Lake IJsselmeer & twice & 1 & eel boxes \\
Lake IJsselmeer & once & 1 & longlines \\
Lake Markermeer & once/twice & 2 & large fyke \\
Lake Markermeer & twice & 1 & longlines \\
\hline PARAMETER & & SAMPLE DETAILs & \\
\hline No. eels for length-frequency & max. 150 eels per sample \\
No. eels for biology (sex, life stage, parasites) & $<50 \mathrm{~cm}: 4$ eels per $10 \mathrm{~cm}$ size class \\
Period & & $\geq 50 \mathrm{~cm}: 2$ eels per $10 \mathrm{~cm}$ size class \\
\hline
\end{tabular}

\subsubsection{Analysis}

The national stock assessment methodology is described in Van de Wolfshaar et al. (2015).

\subsubsection{Age analysis}

Since 2010, age readings have been obtained annually of $\sim 150$ otoliths, which were collected from eels in different areas of the Netherlands. The number of annuli were counted to determine the age of individuals ("crack and burn" method). Furthermore, distances between consecutive annuli were measured using image analysis software to determine individual growth curves.

\subsubsection{Life stages}

Life stages (yellow, silvering, silver) are visually determined based on colouration of body and fins and eye diameter. Criteria for life stages are at present not formally described.

\subsection{Sex determinations}

Sex is determined by macroscopic examination of the gonads.

\subsubsection{Reporting}

Van de Wolfshaar et al. (2015) report on the status of the eel population in the periods 2005-2007, 2008-2010 and 2011-2013.

\subsubsection{Data quality issues and how they are being addressed}




\subsection{Assessment results}

See Van de Wolfshaar et al. (2015)

\subsubsection{Habitat quantities}

See Van de Wolfshaar et al. (2015)

5.2.2 Silver Eel biomass indicators

See Van de Wolfshaar et al. (2015)

5.2.3 Anthropogenic mortality rates

See Van de Wolfshaar et al. (2015) 


\section{Other data collection}

\subsection{International recruitment time series}

No international recruitment series are used.

\subsection{Other recruitment time series}

\subsubsection{Glass eel recruitment}

\subsubsection{Commercial}

Glass eel fisheries is forbidden, NO AVAILABLE DATA

\subsubsection{Recreational}

Glass eel fisheries is forbidden, NO AVAILABLE DATA

\subsubsection{Fishery independent}

Recruitment of glass eel in Dutch waters is monitored at 12 other sites along the coast (Figure NL. 14; see Dekker (2002) for a full description). In Den Oever (Figure NL. 15) recruitment significantly increased in 2013-2014 and was at the highest level since the mid-'90s. However, overall the recruitment levels were still low compared to the reference period (1960-1979) and in 2015 recruitment level reached a historic low, and in 2016 there was a small increase. The data from the other locations (Table NL. U) confirmed the overall trend, though individual series may deviate. Glass eel data are presented as the average number of glass eels per haul in the months April and May, between 18:00-8:00 and only years with $>5$ hauls are included.

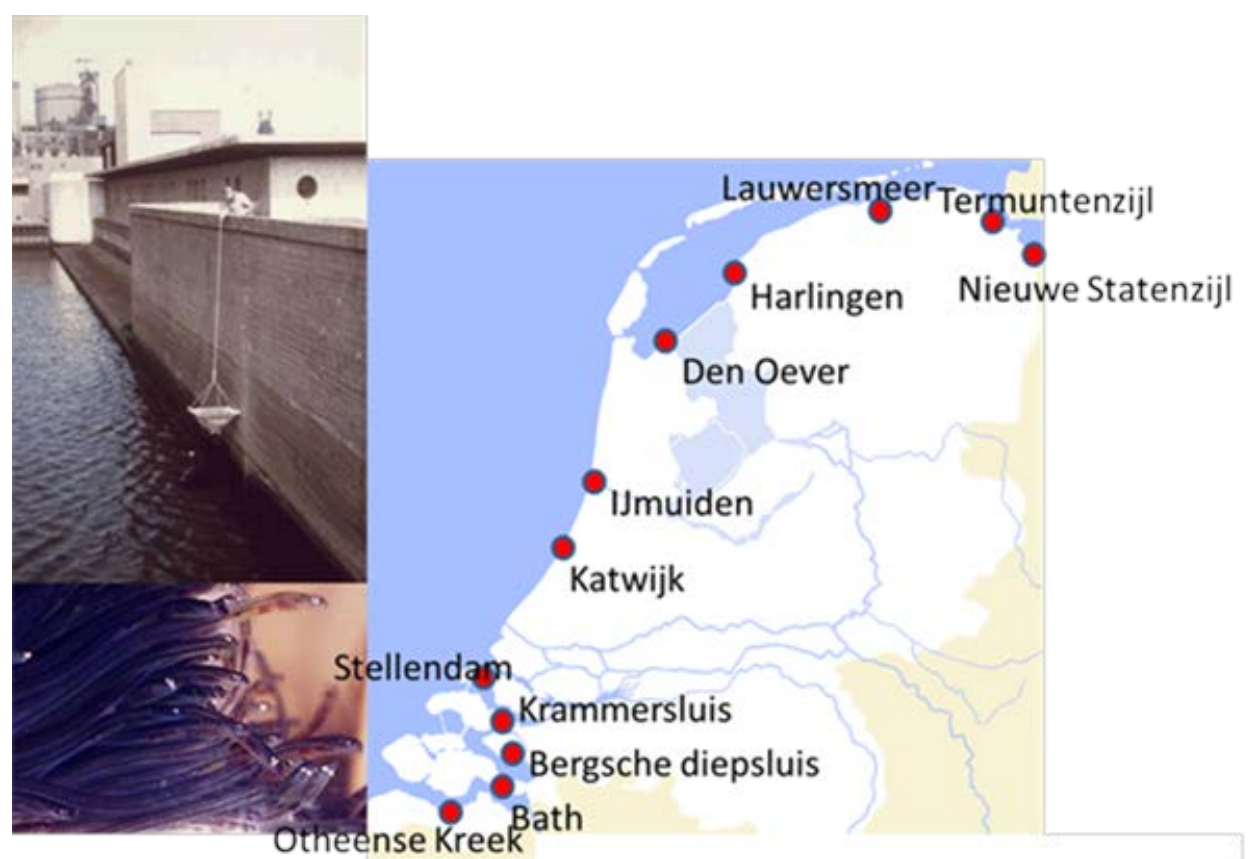

Figure NL. 13. Locations of glass eel monitoring in the Netherlands. 


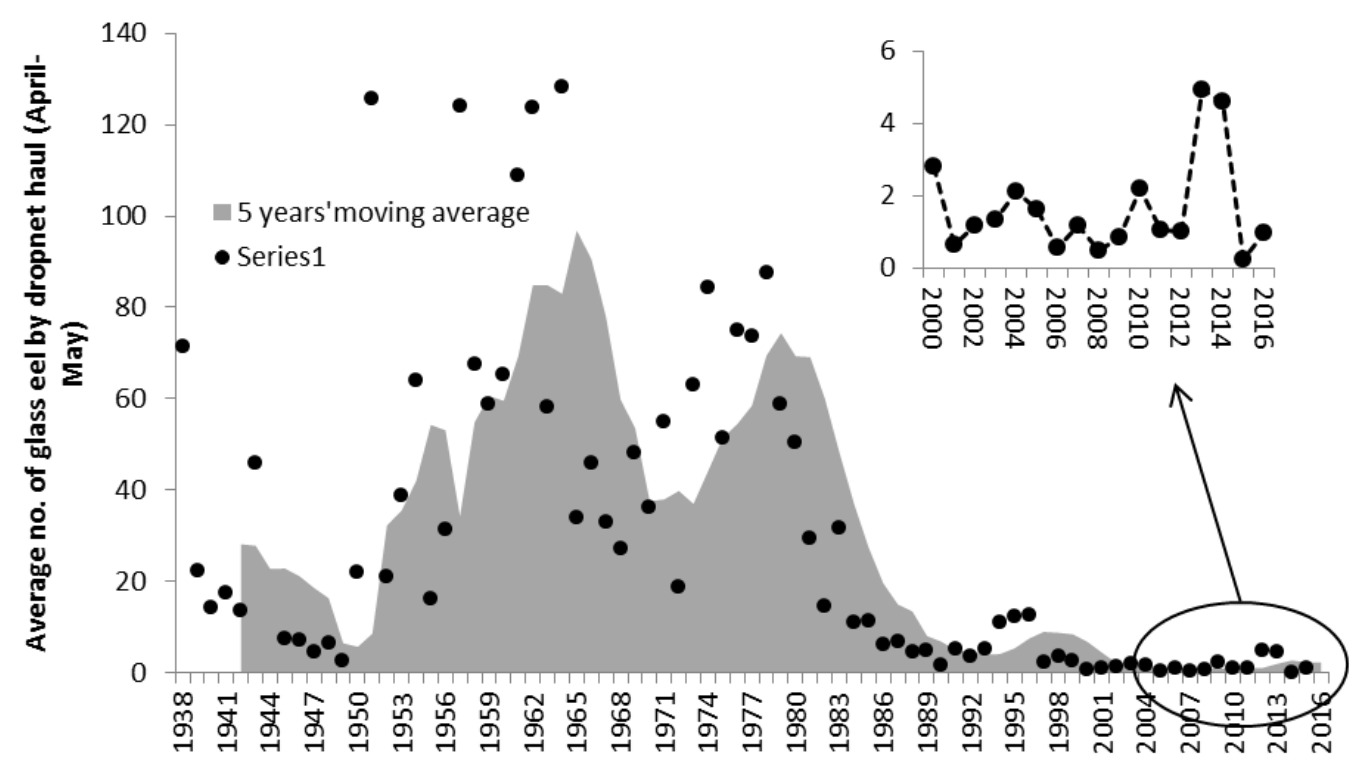

Figure NL. 14 Trend indices (mean number per haul in April and May) of glass eel recruitment at Den Oever (1938-2016).

Table NL. R Average number of glass eel caught per lift net haul at the sluices in Den Oever in the period April-May.

\begin{tabular}{|c|c|c|c|c|c|c|c|c|c|c|}
\hline $\begin{array}{l}\text { DECADE } \\
\text { YEAR }\end{array}$ & & 1930 & 1940 & 1950 & 1960 & 1970 & 1980 & 1990 & 2000 & 2010 \\
\hline & 0 & & 22.4 & 2.7 & 58.9 & 48.1 & 59.0 & 4.9 & 2.8 & 2.2 \\
\hline & 1 & & 14.3 & 21.9 & 65.2 & 36.1 & 50.4 & 1.8 & 0.6 & 1.1 \\
\hline & 2 & & 17.5 & 125.6 & 108.9 & 55.0 & 29.4 & 5.2 & 1.2 & 1.0 \\
\hline & 3 & & 13.7 & 21.1 & 123.7 & 18.8 & 14.7 & 3.5 & 1.3 & 4.9 \\
\hline & 4 & & 46.1 & 38.8 & 58.1 & 63.0 & 31.6 & 5.4 & 2.1 & 4.6 \\
\hline & 5 & & NA & 64.1 & 128.3 & 84.3 & 11.2 & 11.1 & 1.6 & 0.2 \\
\hline & 6 & & 7.5 & 16.1 & 34.0 & 51.4 & 11.4 & 12.5 & 0.6 & 1.0 \\
\hline & 7 & & 7.2 & 31.3 & 45.8 & 75.0 & 6.2 & 12.6 & 1.2 & \\
\hline & 8 & 15.3 & 4.8 & 124.0 & 32.9 & 73.6 & 7.0 & 2.5 & 0.5 & \\
\hline & 9 & 71.5 & 6.6 & 67.6 & 27.1 & 87.7 & 4.8 & 3.7 & 0.9 & \\
\hline
\end{tabular}


Table NL. S Average number of glass eel caught by dropnet hauls between 18:00 and 8:00 hrs in the period April-May at 12 sites in the Netherlands (1979-2016). If five or less hauls were carried out, this was recorded as NA.

\begin{tabular}{|c|c|c|c|c|c|c|c|c|c|c|c|c|}
\hline & 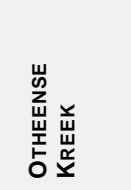 & $\begin{array}{l}I \\
\stackrel{I}{\leftarrow} \\
\Phi\end{array}$ & 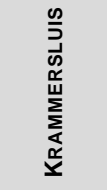 & 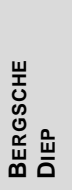 & 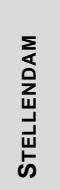 & 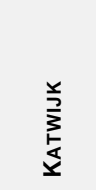 & $\begin{array}{l}z_{u} \\
\underline{a} \\
\sum_{\underline{D}}\end{array}$ & 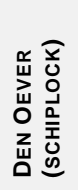 & 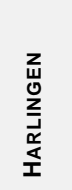 & 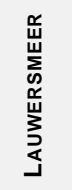 & 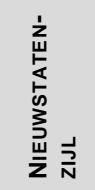 & 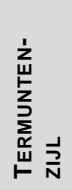 \\
\hline RBD & SCHELDT & & Meuse & & & RHINE & & & & & EMs & \\
\hline 1979 & & & & & & & & & & 100.4 & & \\
\hline \multicolumn{13}{|l|}{1980} \\
\hline 1981 & & & & & & & & & & 75.9 & & \\
\hline 1982 & & & & & & & & & & 21.6 & & \\
\hline 1983 & & & & & & & & & & 15.8 & & \\
\hline 1984 & & & & & & & & & & 9.6 & & \\
\hline 1985 & & & & & & & 0.6 & & & 25.2 & & \\
\hline 1986 & & & & & & & 3.3 & & & 1.3 & & \\
\hline 1987 & & & & & & & 7.7 & & & & & \\
\hline 1988 & & & & & 13.8 & & & & & 1.0 & & \\
\hline 1989 & & & & & 4.4 & & & & & 14.3 & & \\
\hline 1990 & 0.3 & & 0.3 & & 10.9 & & & & & 6.0 & & \\
\hline 1991 & 0.0 & & 0.2 & 1.3 & 3.1 & 5.1 & & & & 6.6 & & 0.5 \\
\hline 1992 & 0.0 & 6.6 & 0.4 & & 16.9 & 9.1 & & & 16.7 & 12.1 & & 0.6 \\
\hline 1993 & 0.0 & 22.7 & 0.4 & & 10.1 & 13.5 & & & & 33.2 & & 1.2 \\
\hline 1994 & 0.0 & 14.2 & 0.5 & & 4.0 & & & & 16.0 & 31.0 & & 2.8 \\
\hline 1995 & 0.5 & & 0.4 & & 3.3 & 29.7 & 2.0 & 34.7 & 6.6 & 16.9 & & 3.7 \\
\hline 1996 & 1.3 & 22 & 0.7 & & 0.5 & 25.3 & & 11.0 & 34.2 & 49.4 & 27.5 & 7.7 \\
\hline 1997 & & & 0.6 & & 2.8 & 12.9 & & 11.4 & 11.2 & 27.8 & 30.0 & 15.6 \\
\hline 1998 & 0.7 & & 0.6 & & 1.0 & 38.8 & 2.0 & 6.5 & 18.3 & 14.4 & 21.8 & 1.4 \\
\hline 1999 & 1.4 & & 0.5 & & 1.2 & 140.1 & & 7.2 & & 31.7 & 12 & 10.2 \\
\hline 2000 & 0.9 & 10.2 & 1.0 & 3.8 & 7.1 & 11.6 & & 5.0 & & 7.2 & 38.8 & 8.7 \\
\hline 2001 & 0.4 & & 0.1 & & 1.0 & & & 1.7 & & 2.4 & 39.7 & 1.1 \\
\hline 2002 & & 1.9 & 0.2 & & 4.2 & 13.2 & 0.1 & 1.4 & 3.2 & 5.5 & 36.4 & 1.6 \\
\hline 2003 & & 7.5 & 0.1 & & 0.3 & 12.7 & & 4.8 & & 1.7 & 23.6 & 0.8 \\
\hline 2004 & 0.0 & $16.4^{2}$ & 0.1 & & 0.3 & 4.5 & & & $14.3^{2}$ & 2.3 & 28.1 & 1.9 \\
\hline 2005 & 0.0 & 15.3 & 0.6 & & 0.2 & 5.6 & & & & 1.4 & 21.1 & 1.8 \\
\hline 2006 & 0.0 & 12.4 & 0.2 & & 0.0 & 1.4 & & 0.3 & 0.6 & 1.7 & 8.3 & 1.3 \\
\hline $2007^{1}$ & 0.0 & 43.9 & 0.1 & 0.4 & 0.1 & 27.9 & 0.1 & & 1.7 & 1.0 & 21.7 & 4.0 \\
\hline 2008 & 0.0 & 13.2 & 0.0 & 2.5 & 0.0 & 4.5 & 0.1 & 0.8 & 1.1 & 2.8 & 15.6 & 1.3 \\
\hline 2009 & 0.0 & 9.1 & 0.0 & 1.3 & 0.5 & 3.5 & 0.1 & & 0.7 & 0.6 & 13.6 & 1.2 \\
\hline 2010 & & 28.4 & 0.0 & 1.7 & 0.2 & & 0.0 & 1.2 & 1.0 & 1.1 & 13.0 & 1.2 \\
\hline 2011 & & 39.2 & 0.1 & 1.3 & 0.3 & & 0.0 & & 3.1 & 1.4 & 11.6 & 1.4 \\
\hline 2012 & & 25.8 & 0.2 & 0.8 & 0.1 & 1.6 & 0.1 & & 1.1 & 2.9 & 27.6 & 1.3 \\
\hline 2013 & & 73.8 & 0.0 & 16.7 & 0.2 & 1.4 & 0.0 & & 5.2 & 9.1 & 60.5 & 1.9 \\
\hline 2014 & & 96.3 & 0.0 & 6.3 & 0.5 & 0.4 & 0.0 & & 5.8 & 16.2 & 72.0 & 2.1 \\
\hline 2015 & & 24.2 & & 2.2 & 0.2 & 0.6 & 0.1 & & 1.0 & & 3.0 & 0.4 \\
\hline 2016 & & 22.8 & 0.0 & 4.7 & 1.0 & 0.7 & 0.0 & & 1.5 & & 31.1 & 0.8 \\
\hline
\end{tabular}

1 = very early season (warm spring), sampling stopped early (early May), low number of empty samples.

2 = sampling took place in part of the season. 


\subsubsection{Yellow eel recruitment}

\subsubsection{Commercial}

NO AVAILABLE DATA.

\subsubsection{Recreational} NO AVAILABLE DATA.

\subsubsection{Fishery independent}

One of the few long time series for eel is the fyke monitoring at NIOZ (Den Burg, Texel; van der Meer et al. 2011) (Fig NL. 4). This data set shows a familiar pattern of a steep decline in abundance since the 1980s.

In the past almost all catches were yellow eel, based on their length. More recently, the catches also comprise silver eel (source: NIOZ).

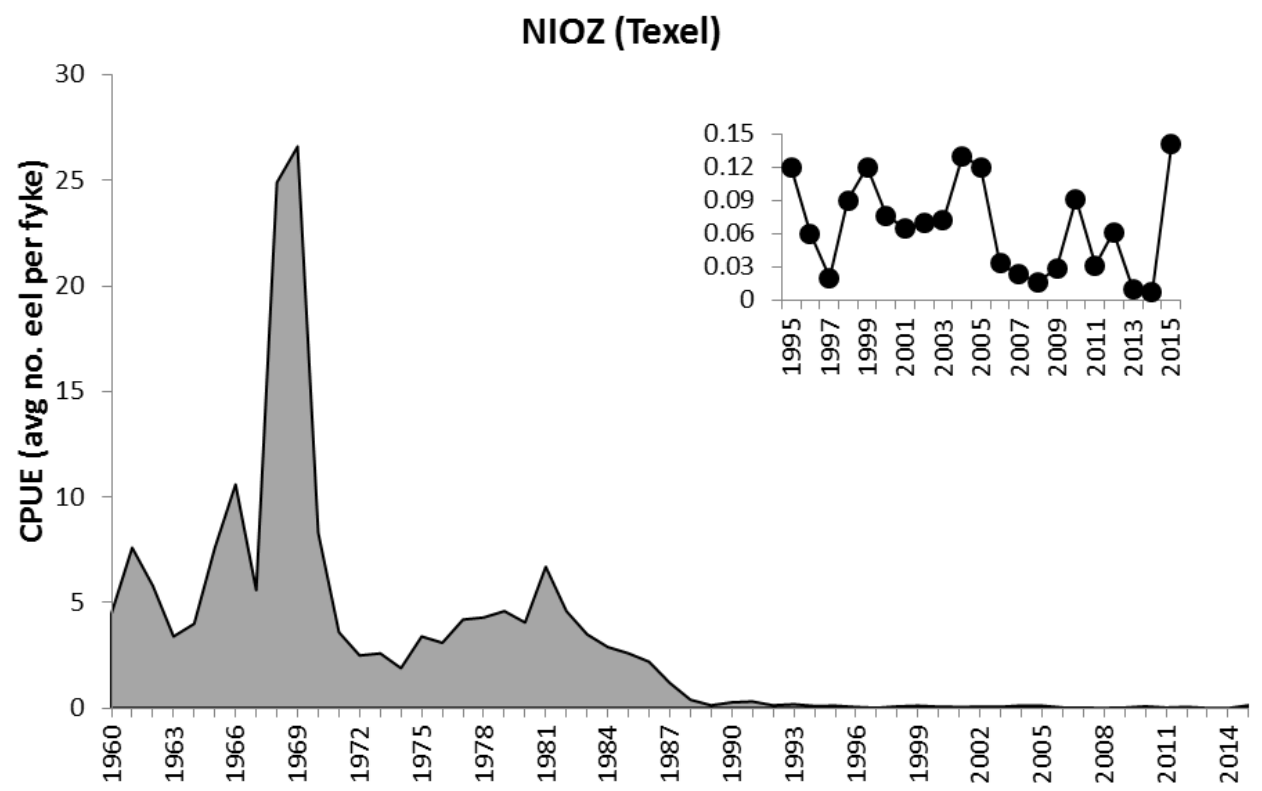

Figure NL. 15 Time series of the mean catch per fyke (numbers) of yellow eel at NIOZ 1960-2015 (data Van der Meer et al., 2011 and NIOZ).

\subsection{National programme for EU Data Collection Framework or other}

Table NL. T. Summary of the DCF monitoring implementation for The Netherlands 2014

\begin{tabular}{|c|c|c|c|c|c|}
\hline Data & River & Lakes & Estuaries & Lagoons & Coastal \& Marine \\
\hline Production / escapement surveys ${ }^{1}$ & Y (WFD) & Y (WFD) & NP & $\mathrm{NP}$ & $\mathrm{NP}$ \\
\hline $\begin{array}{l}\text { No. of recruitment time-series } \\
\text { surveys }{ }^{2}\end{array}$ & 10 & 1 & NP & $\mathrm{NP}$ & $\mathrm{NP}$ \\
\hline No. fished aged & \multicolumn{2}{|c|}{49} & 0 & 0 & 0 \\
\hline No. of fished sexed & \multicolumn{2}{|c|}{280} & 0 & 0 & 0 \\
\hline No. of fish examined for parasites & \multicolumn{2}{|c|}{280} & 0 & 0 & 0 \\
\hline $\begin{array}{l}\text { No. of fish examined for } \\
\text { contaminants }\end{array}$ & \multicolumn{2}{|c|}{ ca. 475 (in 2013) } & 0 & 0 & 0 \\
\hline $\begin{array}{l}\text { No. of non-fishery mortality } \\
\text { studies }^{3}\end{array}$ & 1 & 0 & 0 & 0 & 0 \\
\hline
\end{tabular}




\begin{tabular}{lccccc}
\hline Data & River & Lakes & Estuaries & Lagoons & Coastal \& Marine \\
\hline Socio-economic survey & 0 & 0 & 0 & 0 & 0 \\
\hline
\end{tabular}

${ }^{1}$ Surveys to estimate $B_{\text {best }}$ and/or $B_{\text {current }}$, including WFD surveys of which the data are being used to estimate production and/or escapement of eel

${ }^{2}$ Fishery-independent surveys

${ }^{3}$ Studies to determine $\sum \mathrm{H}$ for non-fisheries anthropogenic impacts (hydropower, barriers, predation, etc.)

\subsection{Stock surveys, yellow eel}

\subsubsection{Lake IJ sselmeer/Markermeer (active gear)}

Figure NL. 17 presents the trends in CPUE for the annual (yellow) eel surveys in Lake IJsselmeer (25 sites) and Lake Markermeer (15 sites), using the electrified trawl.

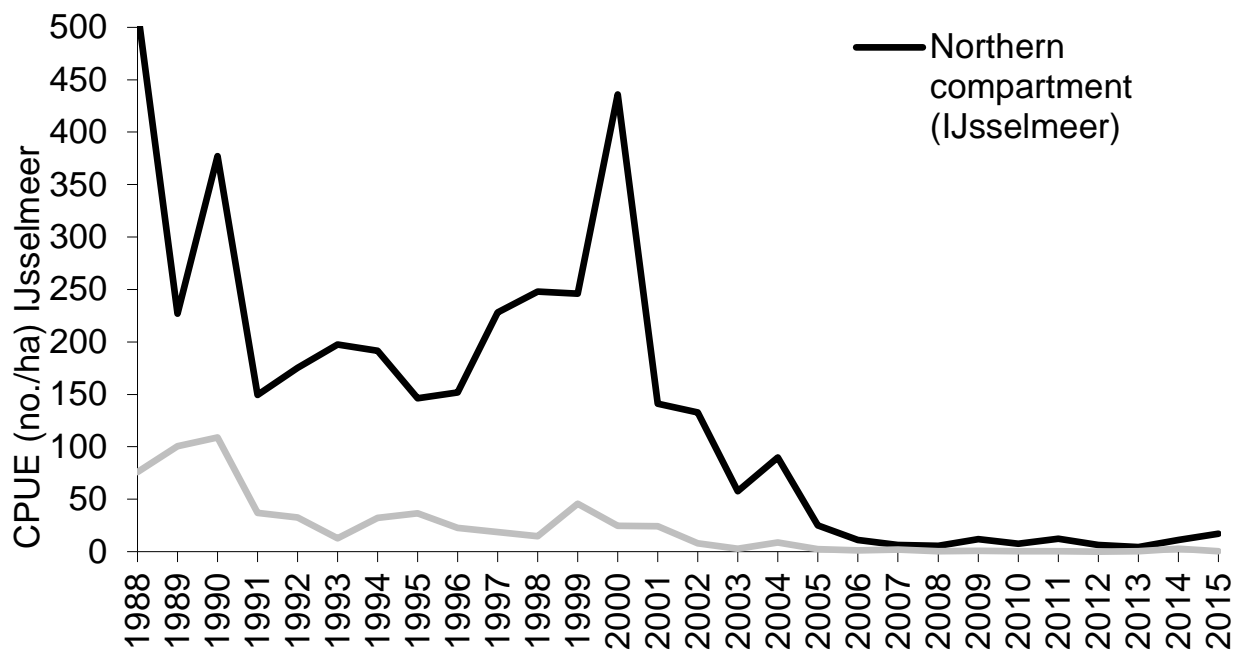

Figure NL. 16. CPUE trends in Lake IJ sselmeer stock surveys, in number per hectare swept area, using the electrified trawl. Note: The northern and southern compartments have been separated by a dyke since 1976.

\subsubsection{Main rivers (active gear)}

Data collected for the main rivers, but not (yet) available.

\subsubsection{Main rivers (passive gear)}

No new data.

\subsubsection{Coastal waters (active gear)}

The number of eels caught in a coastal survey (Demersal young Fish Survey) is presented in Figure NL.14. Until the mid-1980s, considerable catches of eel were observed, after which a gradual decrease was observed. A more elaborate statistical analysis of the abundance and length composition of the eel stock in coastal waters is presented in Dekker (2009). 

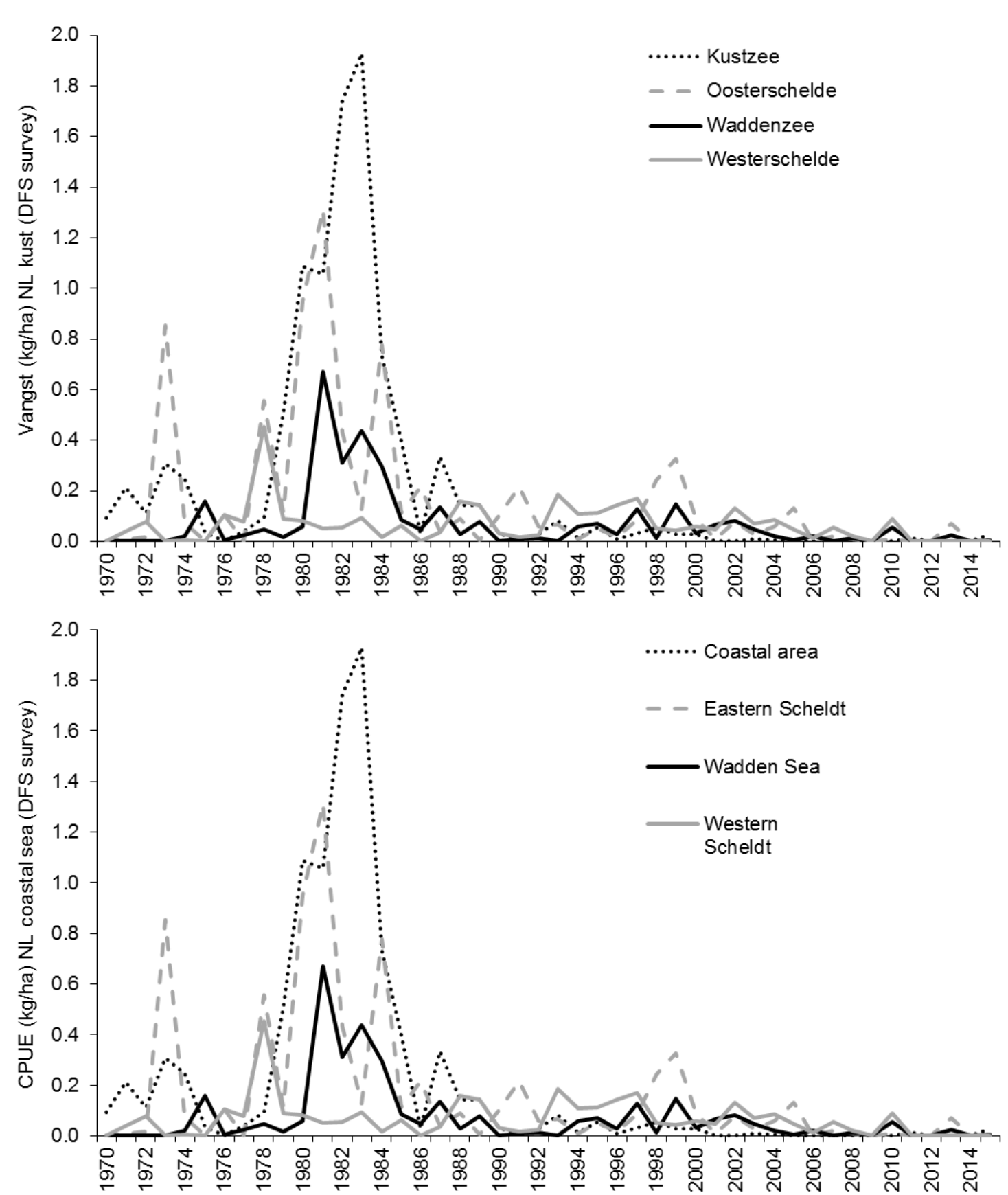

Figure NL. 17. Trends in coastal survey CPUE 1970-2015. Top graph: n/ha; lower graph: kg/ha. Most of the Wadden Sea belongs to RBD Rhine; Eastern Scheldt is mixed RBD Scheldt and Meuse; Western Scheldt belongs to RBD Scheldt (with an extra inflow from Meuse), the coastal area belongs to RBD Rhine (data: IMARES).

\subsection{Silver eel escapement surveys}

The Silver Eel Index has been implemented in the Netherlands since 2012. In co-operation with commercial fishermen the abundance of migrating silver eel is monitored on seven locations (main entry and exit points for migratory fish) during the months September-November. The programme and the results will be presented and discussed when sufficient data will become available, after at least five years. Due to irregular activities of participating fishermen in the research programme significant gaps in the data series already exist, especially for the locations at Den Oever and Kornwerderzand. 


\subsection{Biological parameters}

See Bierman et al. 2012.

\subsection{Growth, silvering and mortality}

See Bierman et al. 2012.

\subsection{Parasites \& Pathogens}

The swim bladder nematode Anguillicoloides crassus was introduced from South-East Asia in wild stocks of European eel in The Netherlands in the early 1980s. The market sampling for Lake IJ sselmeer collects information on eels showing Anguillicoloides crassus infection based on inspection of the swim bladder by the naked eye. We scored an infection as 'present' when either we observed one or more Anguillicoloides crassus or a thickened swim bladder. As part of the extended market sampling program in 2009, data on Anguillicoloides infection rates have since also been collected in two other areas (Friesland and Rivers), and since 2011 the market sampling was conducted in most of the Netherlands.

Following the initial break-out in the late 1980s, infection rates in Lake IJ sselmeer have been stable around $50 \%$. Over the past year, infection rates appear slightly lower both in Lake Markermeer and on average in the rest of the Netherlands (Table NL. W).

Table NL. U Infection rates of eels (2010-2015) with Anguillicoloides crassus in the Netherlands. Median infection rates of all sampled locations.

\begin{tabular}{lllllllll}
\hline & FRYSLAN & & $\begin{array}{l}\text { LAKE } \\
\text { IJSSELMEER }\end{array}$ & & $\begin{array}{l}\text { LAKE } \\
\text { MARKERMEER }\end{array}$ & \multicolumn{3}{c}{$\begin{array}{l}\text { REST } \\
\text { NL }\end{array}$} \\
\hline & N eels & $\begin{array}{l}\% \\
\text { infected }\end{array}$ & N eels & $\begin{array}{l}\% \\
\text { infected }\end{array}$ & N eels & $\begin{array}{l}\% \\
\text { infected }\end{array}$ & N eels & $\begin{array}{l}\% \\
\text { infected }\end{array}$ \\
\hline 2010 & 534 & $46 \%$ & 390 & $49 \%$ & 225 & $48 \%$ & 511 & $50 \%$ \\
\hline 2011 & 107 & $37 \%$ & 293 & $43 \%$ & 104 & $34 \%$ & 583 & $40 \%$ \\
\hline 2012 & 133 & $33 \%$ & 320 & $52 \%$ & 253 & $38 \%$ & 529 & $35 \%$ \\
\hline 2013 & 17 & $47 \%$ & 14 & $50 \%$ & 93 & $43 \%$ & 428 & $44 \%$ \\
\hline 2014 & 49 & $63 \%$ & 202 & $50 \%$ & 46 & $26 \%$ & 321 & $40 \%$ \\
\hline 2015 & 62 & $18 \%$ & 267 & $35 \%$ & NC & & 297 & $28 \%$ \\
\hline
\end{tabular}




\subsection{Contaminants}

In 2015, 15 locations were sampled to assess contaminant levels (sum-TEQ and sum Non-dioxin-like PCBs) in eel. Samples consisted of about 25 individuals, $30-40 \mathrm{~cm}$ or $>45 \mathrm{~cm}$ length, and filets were pooled prior to analysis (Table NL-O).

Contaminant concentrations are higher in larger eel than in smaller eel from the same locations. In 2015, several samples had contaminant levels above the revised regulatory limits of 2012 ( $10 \mathrm{pg} / \mathrm{g}$ Sum TEQ ${ }^{4}$ and $350 \mathrm{ng} / \mathrm{g}$ Sum Non-dioxin-like $\mathrm{PCBs}^{5}, 10 \%$ uncertainty included). All locations that did have eels with a concentration of Sum TEQ or Sum Non-dioxin-like PCBs above the regulatory levels were fed by the rivers Rhine (IJ ssel) and Meuse.

Since 1978/1979 several locations have been monitored annually for PCBs. The levels for PCB 153 are shown in Figure NL. 15. Concentrations in 2015 were about similar to those in previous years.

Decrease of PCB-contamination occurs very slowly, if any.

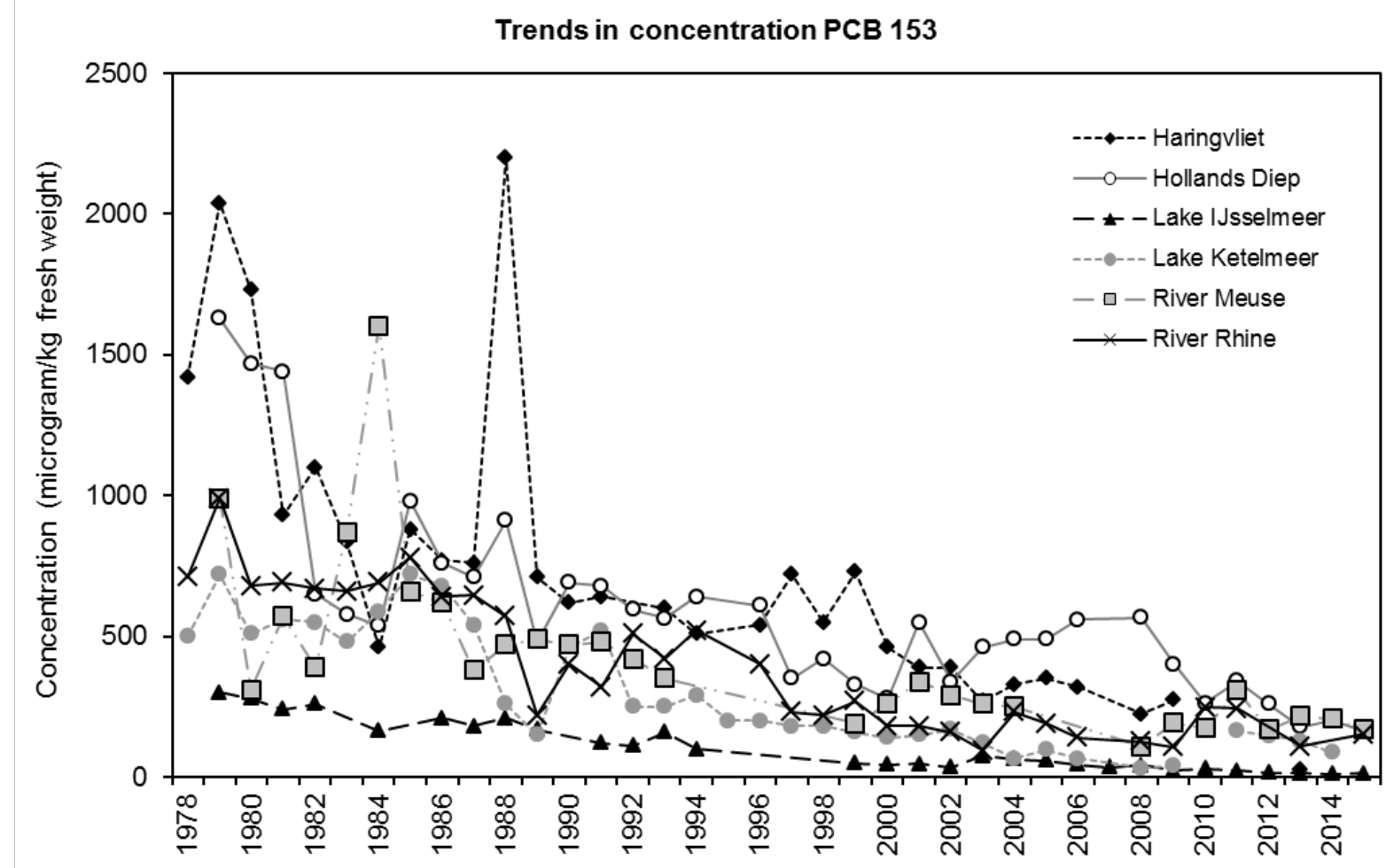

Figure NL. 18. Trend in PBC-153 in 30-40 cm eel (1978-2015) (data: IMARES and RIKILT).

\footnotetext{
${ }^{4}$ TEQ=Toxic Equivalent: sum of dioxines, furanes and dioxine-like PCBs

${ }^{5}$ Sum of 6 PCBs including PCB153. These are non-toxic indicator PCBs that can be measured easily.
} 
Table NL. V. Monitoring data of PCBs in eel in the Netherlands 2015. Values of Sum-TEQ above $11 \mathrm{pg} / \mathrm{g}(10+10 \% * 10)$ are above the regulatory limit.

\begin{tabular}{|c|c|c|c|c|c|}
\hline $\begin{array}{l}\text { IMARES } \\
\text { sample nr }\end{array}$ & Area & $\begin{array}{r}\text { Fat content } \\
(\%)\end{array}$ & diox tec & $\begin{array}{r}\text { WHO2005- } \\
\text { dl-PCB- } \\
\text { TEQ (ub) }\end{array}$ & $\begin{array}{r}\text { Sum-TEQ } \\
(\mathrm{pg} / \mathrm{g})\end{array}$ \\
\hline $2015 / 1004$ & IJssel, Deventer $30-40 \mathrm{~cm}$ & 5.2 & 0.51 & 4.42 & 4.92 \\
\hline $2015 / 1030$ & IJssel, Deventer $>45 \mathrm{~cm}$ & 19.2 & 3.16 & 17.82 & 20.98 \\
\hline $2015 / 1108$ & Lek Culemborg 30-40 cm & 4.7 & 0.52 & 3.70 & 4.22 \\
\hline $2015 / 1134$ & Lek Culemborg $>40 \mathrm{~cm}$ & 16.3 & 3.53 & 14.13 & 17.66 \\
\hline $2015 / 1264$ & Volkerak, Dintelsas 30-40 cm & 7.9 & 0.97 & 2.65 & 3.62 \\
\hline $2015 / 1290$ & Volkerak, Dintelsas $>45 \mathrm{~cm}$ & 15.1 & 2.27 & 5.31 & 7.57 \\
\hline $2015 / 1160$ & Maas, Eijsden 30-40 cm & 4.9 & 0.29 & 4.54 & 4.83 \\
\hline $2015 / 1186$ & Maas, Eijsden $>45 \mathrm{~cm}$ & 19.5 & 1.13 & 18.01 & 19.14 \\
\hline $2015 / 1212$ & Rijn, Lobith $30-40 \mathrm{~cm}$ & 5.5 & 0.75 & 7.68 & 8.43 \\
\hline $2015 / 1238$ & Rijn, Lobith $>45 \mathrm{~cm}$ & 17.9 & 2.09 & 15.61 & 17.70 \\
\hline $2015 / 1368$ & IJsselmeer, Lemmer 30-40 cm & 9.8 & 0.55 & 1.46 & 2.01 \\
\hline $2015 / 1394$ & IJsselmeer, Lemmer $>45 \mathrm{~cm}$ & 23.0 & 0.95 & 2.68 & 3.63 \\
\hline $2015 / 1316$ & Waal, Tiel $30-40 \mathrm{~cm}$ & 5.2 & 0.61 & 6.34 & 6.95 \\
\hline $2015 / 1342$ & Waal, Tiel $>45 \mathrm{~cm}$ & 18.1 & 3.38 & 22.19 & 25.58 \\
\hline $2015 / 1472$ & AR kanaal, Rijswijk 30-40 cm & 4.6 & 1.10 & 4.10 & 5.20 \\
\hline $2015 / 1498$ & AR kanaal, Rijswijk $>45 \mathrm{~cm}$ & 23.5 & 7.11 & 18.76 & 25.87 \\
\hline $2015 / 1628$ & Neder-Rijn, Driel $>45 \mathrm{~cm}$ & 21.8 & 5.62 & 26.25 & 31.87 \\
\hline $2015 / 1524$ & Volkerak, Krammersluis $30-40 \mathrm{~cm}$ & 4.8 & 0.40 & 1.32 & 1.72 \\
\hline $2015 / 1550$ & Volkerak, Krammersluis $>45 \mathrm{~cm}$ & 18.1 & 1.60 & 3.92 & 5.52 \\
\hline $2015 / 0952$ & Hollands-Diep 30-40 cm & 11.2 & 1.26 & 5.55 & 6.81 \\
\hline $2015 / 0978$ & Hollands-Diep $>45 \mathrm{~cm}$ & 21.3 & 3.93 & 14.75 & 18.68 \\
\hline $2015 / 1056$ & IJsselmeer, Medemblik 30-40 cm & 7.2 & 0.59 & 1.17 & 1.75 \\
\hline $2015 / 1082$ & IJsselmeer, Medemblik $>45 \mathrm{~cm}$ & 16.6 & 0.92 & 2.22 & 3.14 \\
\hline $2015 / 1420$ & Jan v Riebeekhaven & 13.4 & 11.4 & 6.67 & 18.1 \\
\hline $2015 / 3104$ & Biesbosch De Gijster $>45 \mathrm{~cm}$ & 19.5 & 1.31 & 8.07 & 9.38 \\
\hline $2015 / 1576$ & Biesbosch 100 en 30 30-40 cm & 4.10 & 0.39 & 2.13 & 2.52 \\
\hline $2015 / 1602$ & Biesbosch 100 en $30>45 \mathrm{~cm}$ & 8.05 & 0.98 & 5.98 & 6.96 \\
\hline $2015 / 3168$ & 2de Maasvlakte $30-40 \mathrm{~cm}$ & 4.13 & 0.46 & 1.42 & 1.88 \\
\hline $2015 / 3194$ & 2de Maasvlakte $>45 \mathrm{~cm}$ & 13.4 & 1.39 & 3.09 & 4.48 \\
\hline
\end{tabular}

\subsection{Predators}

Predation of eel by cormorants (Phalacrocorax carbo) is much disputed amongst eel fishermen and bird protectors. The number of cormorant breeding pairs increased rapidly until the early 1990s, then stabilised and even decreased in recent years (Figure NL. 20). For Lake IJ sselmeer, food consumption has been well quantified (van Rijn \& van Eerden 2001; van Rijn 2004); eel constitutes a minor fraction of the diet of cormorants. In other waters, neither the abundance, nor the food consumption is accurately known. 


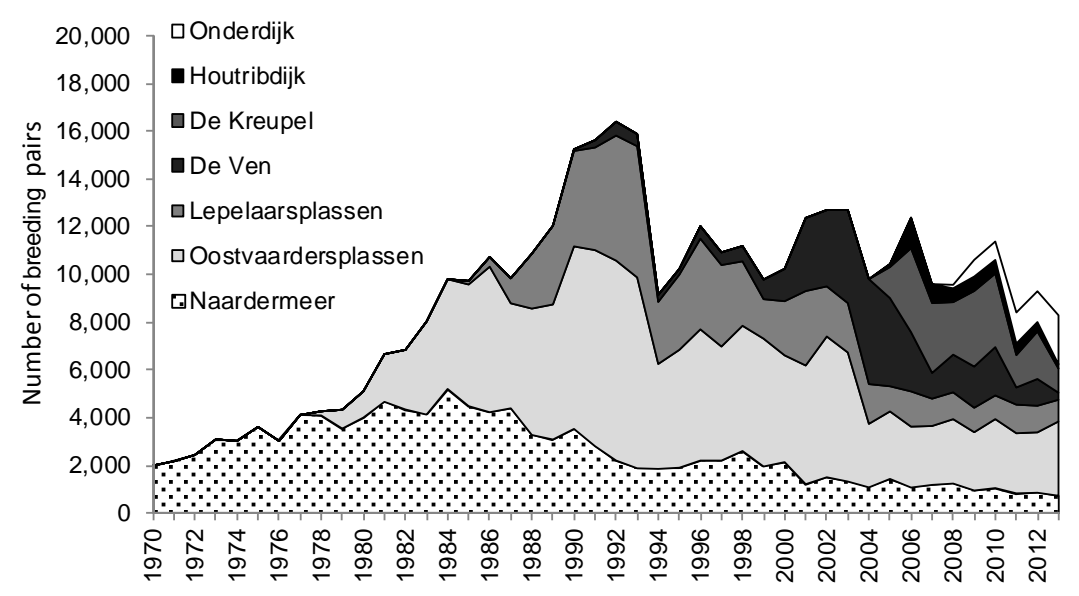

Figure NL. 19. Trends in the number of breeding pairs of cormorants (Phalacrocorax carbo) in and around Lake IJ sselmeer/Markermeer (Source: Waterdienst RWS) (1970-2013). Data for 2014 and 2015 were not made available.

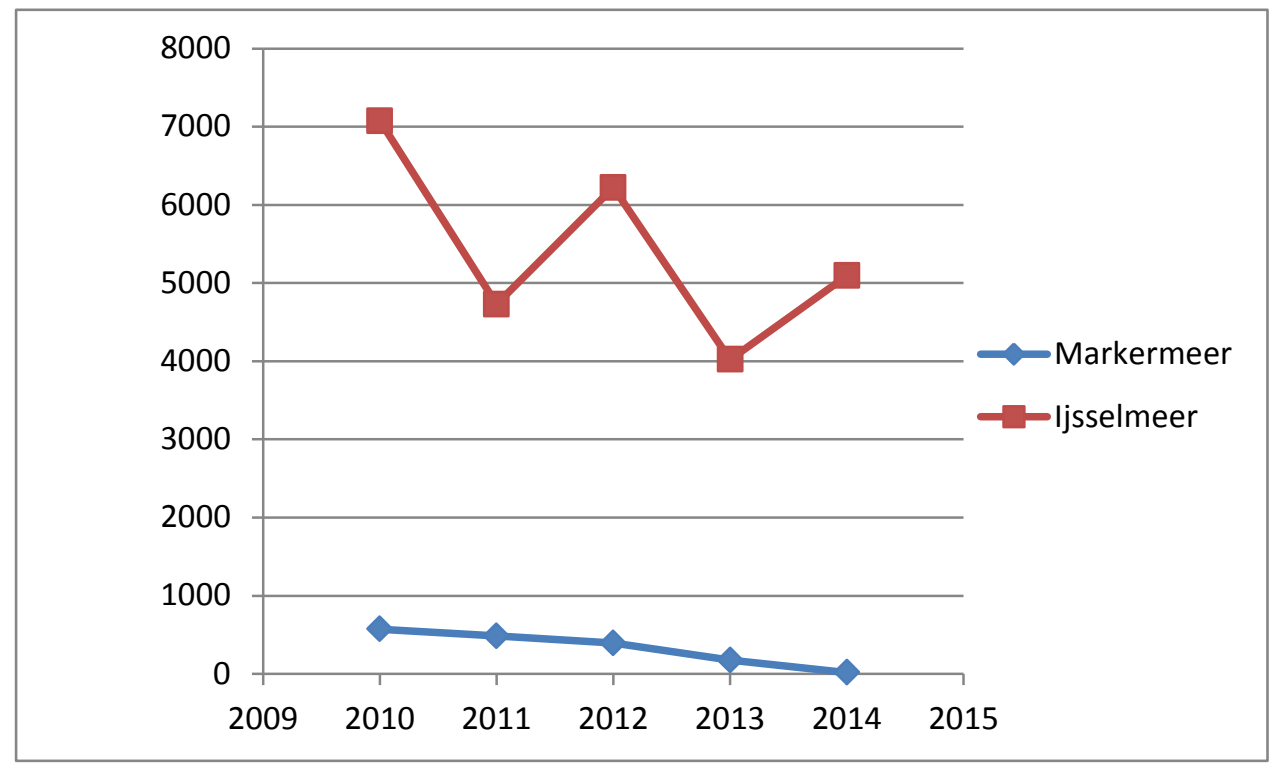

Figure NL. 20. Trends in the number of breeding pairs of cormorants (Phalacrocorax carbo) in and around Lake IJ sselmeer/Markermeer (Source: Netwerk Ecologische Monitoring, Sovon \& CBS) (20102014). 


\section{Quality Assurance}

Wageningen Marine Research utilises an ISO 9001:2008 certified quality management system (certificate number: 187378-2015-AQ-NLD-RvA). This certificate is valid until 15 September 2018. The organisation has been certified since 27 February 2001. The certification was issued by DNV Certification B.V. 


\section{References}

Bartholomew A. and J. Bohnsack. (2005). A review of catch-and-release angling mortality with implications for no-take reserves. Reviews in Fish Biology and Fisheries, 15: 129-154.

Bierman, S.M., N. Tien , K.E. van de Wolfshaar., H.V. Winter and M. de Graaf (2012). Evaluation of the Dutch Eel Management Plan 2009 - 2011. I mares report C067/12.

De Graaf, M., O.G. Bos (2016). Report on the eel stock and fishery in the Netherlands 2014/2015. IMARES report C044/16.

Dekker, W. (ed.) (2002). Monitoring of glass eel recruitment. Netherlands Institute of Fisheries Research, IJ muiden, Report C007/02-WD, 256 pp.

Dekker, W. (1991). Assessment of the historical downfall of the IJ sselmeer fisheries using anonymous inquiries for effort data. - In: I.G. Cowx (ed.): Catch Effort Sampling Strategies, their Application in Freshwater Management, pp. 233-240. Fishing News Books, Oxford. 420 pp.

Dekker, W. (2008). Coming to Grips with the Eel Stock Slip-Sliding Away. pages 335-355 in M.G. Schlechter, N.J. Leonard and W.W. Taylor, editors. International Governance of Fisheries Ecosystems: Learning from the Past, Finding Solutions for the Future. American Fisheries Society, Symposium 58, Bethesda, Maryland.

Dekker, W. (2009). Bottom trawl surveys in the southern North Sea. Working document presented to the Study Group on Anguillid Eels in Saline Waters, Goteborg Sweden, 3-5 September 2009, 11 pp.

ICES (2016). ICES Advice on fishing opportunities, catch, and effort Northeast Atlantic: 9.3.8 European eel (Anguilla anguilla) throughout its natural range.

Tien, N. and W. Dekker (2004). Trends in eel habitat abundance in the Netherlands during the 20th century. ICES C.M. 2004/S: 12 (mimeo).

Van de Wolfshaar, K.E., Tien, N., Griffioen, A.B., Winter, H.V. and M. de Graaf (2015). Evaluation of the Dutch Eel Management Plan 2015: status of the eel population in the periods 2005-2007, 2008-2010 and 2011-2013. I MARES report C078/15. http://edepot. wur. nl/344169

Van der Hammen, T. and M. de Graaf (2012). Recreational fishery in the Netherlands: catch estimates of cod (Gadus morhua) and eel (Anguilla anguilla) in 2010. I MARES report C014/12, pp. 61.

Van der Hammen, T. and M. de Graaf (2013). Recreational fishery in the Netherlands: demographics and catch estimates in marine and fresh water. IMARES report C147/13. http://edepot. wur.nl/279478

Van der Hammen, T. and M. de Graaf (2015). Recreational fisheries in the Netherlands: analyses of the 2012-2013 online logbook survey, 2013 online screening survey and 2013 random digit dialing screening survey. IMARES report C042/15. http://edepot. wur. nl/338449

Van der Meer, J., H.W. van der Veer. and J.IJ. Witte (2011). The disappearance of the European eel from the western Wadden Sea. Journal of Sea Research 66; 434-439.

Van Rijn S. and M.R. van Eerden (2001). Aalscholvers in het IJ sselmeergebied: concurrent of graadmeter? [Cormorants in the IJ sselmeer area: competitor or indicator?] RIZA report 2001.058.

Van Rijn, S. (2004). Monitoring Aalscholvers in het IJ sselmeergebied [Monitoring cormorants in the IJ sselmeer area]. Voortgangsverslag 2004. RIZA working document 2004.187x.

Van der Sluis M.T., Tien N.S.H., Griffioen A.B., Van Keeken O.A., Van Os-Koomen E., Rippen A.D. and Van de Wolfshaar K.E. (2015). Toestand vis en visserij in de zoete Rijkswateren. Deel II: Methoden, I MARES Wageningen UR.

Winter, H.V,. A.B. Griffioen and K.E. van de Wolfshaar (2013). Knelpunten inventarisatie voor de uittrek van schieraal t.b.v. 'Paling Over De Dijk' Report C134/13, pp. 20. 


\section{J ustification}

Report C003/17

Project Number: 4311209026

The scientific quality of this report has been peer reviewed by a colleague scientist and a member of the Management Team of Wageningen Marine Research

Approved: $\quad$ Ir. O.A. van Keeken

researcher

Signature:

Date:

$18 / 01 / 2017$

Approved: $\quad$ Dr. ir. T.P. Bult Director

Signature:

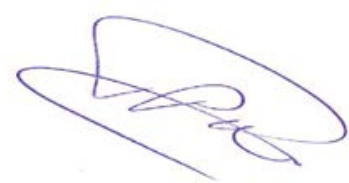

Date:

$18 / 01 / 2017$ 
Wageningen Marine Research

T +31 (0)317 480900

E: marine-research@wur.nl

www.wur.eu/marine-research

Visitors' address

- Ankerpark 271781 AG Den Helder

- Korringaweg 5, 4401 NT Yerseke

- Haringkade 1, 1976 CP IJ muiden
Wageningen Marine Research is the Netherlands research institute established to provide the scientific support that is essential for developing policies and innovation in respect of the marine environment, fishery activities, aquaculture and the maritime sector.

\section{Wageningen University \& Research:}

is specialised in the domain of healthy food and living environment.

\section{The Wageningen Marine Research vision}

'To explore the potential of marine nature to improve the quality of life'

\section{The Wageningen Marine Research mission}

- To conduct research with the aim of acquiring knowledge and offering advice on the sustainable management and use of marine and coastal areas.

- Wageningen Marine Research is an independent, leading scientific research institute

Wageningen Marine Research is part of the international knowledge organisation Wageningen UR (University \& Research centre). Within Wageningen UR, nine specialised research institutes of the Stichting Wageningen Research Foundation have joined forces with Wageningen University to help answer the most important questions in the domain of healthy food and living environment. 